UNIVERSIDADE DE SÃo PAULO

FACUldade de Filosofia, Letras E CiênCias Humanas

DEPARTAMENTO DE LINGUÍSTICA

Programa de Pós-GraduaÇão em Semiótica e Linguística Geral

\title{
Entre Expressões e Conteúdos do semissimbolismo às categorias tensivas
}

CAROLina Lindenberg LEMOS

DisSERTAÇÃo APRESENTADA AO PROGRAMA DE PÓS-GRAduAÇÃo EM SEMIÓtICA E LINGUÍSTICA GERAL DO DEPARTAMENTO DE LINGUÍSTICA DA FACULDADE DE FILOSOFIA, LETRAS E CIÊNCIAS HUMANAS DA UNIVERSIDADE DE SÃo PAULO PARA A OBTENÇÃO DO TÍtUlo DE MESTRE EM LINGUísticA.

Orientador: Prof. Titular Dr. Luiz Augusto de Moraes Tatit

São Paulo

2010 
Um objeto imperfeito que esconde e revela a minha "nostalgia da perfeição". 


\section{Agradecimentos}

Ao Prof. Luiz Tatit, pelas ideias inspiradoras, pela leitura tão afiada e por sempre me botar em movimento, quando não consigo caminhar sozinha.

Ao Ivã Carlos Lopes, a quem devo muito do meu gosto pela semiótica. Porque me ensinou muito do que escrevi nesta dissertação, ela é também um pouco sua.

À Prof ${ }^{a}$ Evani Viotti, com carinho, porque apostou em mim desde o início.

À Prof ${ }^{a}$ Norma Discini, pelas excelentes contribuições ao meu trabalho em geral e ao meu exame de qualificação em particular.

À Prof ${ }^{a}$ Diana L. P. Barros, pela grande arguição em minha qualificação. Muitas de suas sugestões foram incorporadas nesta versão.

Às professoras Esmeralda Negrão, Ana Paula Scher e os tantos outros professores do Departamento de Linguística que alimentaram a minha paixão pela disciplina.

Aos professores de semiótica: José Luiz Fiorin, Waldir Beividas, Elizabeth Harkot-de-la-Taille e Antônio Vicente Pietroforte.

À Érica, ao Robson e ao Ben Hur, por ajudas incontáveis. 
Aos colegas do Grupo de Estudos Semióticos da USP, à Bruna Zerbinatti, à Juliana Pondian, à Carolina Tomasi e, em especial, à Dayane Almeida e à Camila Ribeiro, que dividiram crises e euforias em meio às páginas de semiótica.

Aos colegas do grupo de estudos Clássicos da Linguística - grande empreitada!

À Juliana Nasser, que vem comigo de muito tempo e espero vá sempre estar por perto.

À Renata Moreira, pelo entusiasmo e boas discussões.

À Oriana Fulaneti, que muito admiro por ser assim tão diferente de mim.

À Renata Mancini, pelas contribuições à minha formação em semiótica tensiva.

Ao José Roberto do Carmo Jr., pelas ajudas diretas a partes desta dissertação e pelo inspirador senso linguístico.

Ao Francisco Merçon, o melhor leitor que eu podia esperar, pelas críticas e discussões tão preciosas.

À Mariana Luz P. de Barros, admirável pesquisadora e pessoa incrível.

Ao Paulo, pela forma, à Helena, pela substância, e à Letícia, pelas continuidades e descontinuidades. À Dora, “qui n'est pas (encore) est (déjà) voilà l'attente".

Ao CNPq, pela bolsa concedida para esta pesquisa. 


\section{Resumo}

A noção de semissimbolismo trouxe para a semiótica da Escola de Paris a possibilidade de um estudo mais sistemático das contribuições da expressão para o sentido do texto. A partir de então, foi possível reconhecer categorias no nível da manifestação textual que eram homologadas a pares de oposição no conteúdo. Apesar do ganho teórico que representou, o semissimbolismo guardava ainda limitações, principalmente porque estabelecia relações transitórias e contingentes, que não permitiam uma comparação entre objetos distintos. Com os desenvolvimentos da semiótica tensiva, novas perspectivas de relacionar expressão e conteúdo foram abertas. Ao se valer de termos vindos de componentes expressivos, a semiótica de Claude Zilberberg propôs categorias suficientemente gerais para que fossem aplicáveis aos dois planos da linguagem. Assim, tudo ocorre como se as categorias semissimbólicas, que formavam pares específicos para expressão, de um lado, e conteúdo, de outro, encontrassem na semiótica tensiva o termo complexo que reúne as categorias de cada plano num nível mais abstrato de análise. Tomando como objeto um conjunto de filmes publicitários, o presente trabalho propõe testar e estender os usos da semiótica tensiva, a fim de investigar (i) de que forma a tensividade está presente nas categorias semissimbólicas; (ii) como o instrumental teórico da semiótica tensiva poderia ser aplicado tanto a categorias do conteúdo quanto a categorias da expressão; (iii) quais elementos da expressão seriam relevantes na composição da cifra tensiva dos textos que compõem o nosso corpus; e (iv) como se pode partir diretamente de figuras da expressão e do conteúdo para a análise tensiva, sem que seja necessário fazer uso das categorias semissimbólicas. A natureza sincrética dos anúncios estudados 
traz questões acerca da relação entre as diferentes dimensões expressivas (musical, verbal, visual). Da análise de cada filme pudemos extrair generalizações sobre o conjunto dos anúncios que revelaram (i) suas semelhanças e diferenças em relação ao uso da câmera e da música, (ii) o papel desempenhado pelos elementos repetitivos na cifra tensiva e (iii) uma estrutura de clímax comum a todas as peças. Em nossas conclusões, voltamos à relação entre expressão e conteúdo para, somada às generalizações traçadas, apresentar uma forma de interação entre os planos da linguagem nos quadros da semiótica tensiva.

PALAVRAS-CHAVE: semiótica tensiva; semissimbolismo; filme publicitário; enunciação; persuasão 


\section{Abstract}

In the framework of French Semiotics, the concept of semisymbolism enabled a more systematic study of the contributions of the expression to the meaning in texts. It became possible to recognize categories on the level of manifestation of texts that would then be homologated to opposing pairs in the content. Though it meant a great theoretical gain, semisymbolism still had limitations, mainly because the relations it established were contingent and transitory, and, therefore, did not allow for a comparison between different objects. With the developments of the Tensive Model, new ways of relating expression and content were envisaged. Borrowing terms from the expression component, Claude Zilberberg proposed categories that were sufficiently broad to be applied to both planes of the linguistic sign. Under this new perspective, the tensive categories could be seen as the complex term that would link, on a more abstract level, the semisymbolic categories for the expression, on the one side, and for the content, on the other. Having as object of analysis a set of advertisement films, this study proposes to test and extend the uses of the Tensive Model, with the purpose of investigating (i) how tensive categories underlie the semisymbolic ones; (ii) how to apply the theoretical tools of Tensive Semiotics to both content and expression; (iii) which elements of the expression may be relevant to the constitution of the tensive curve of the texts that compose our corpus; and (iv) how to go directly from the figures of expression and content to the tensive analysis, without resorting to semisymbolic categories. The syncretic nature of the advertisements selected raises questions on the relation between different expressive dimensions (musical, verbal, visual). From the analysis of each film, we were able to make generalizations on the group of advertisements 
that emphasized (i) their differences and similarities in relation to the use of camera and music, (ii) the role played by repetitive structures in the tensive curve, and (iii) the climax structure common to all the films. In our conclusions, we returned to the relation between expression and content, in the light of the generalizations proposed, to present a new form of interaction between the two planes of the linguistic sign in the perspectives of Tensive Semiotics.

KEYWORDS: tensive semiotics; semisymbolism; advertisement film; enunciation; persuasion 


\section{Sumário}

Resumo $\mathbf{v}$

Abstract vii

Lista de Figuras $\quad$ xi

Sobre o CD de Vídeo $\quad$ xi

1 Introdução 1

1.1 A Escolha de um Objeto . . . . . . . . . . . . . . 3

1.2 Do Semissimbolismo à Tensividade . . . . . . . . . . . . 6

2 Cognição e Paixão numa Publicidade do Ministério da Justiça Francês $\quad 15$

2.1 Valores na Publicidade Institucional . . . . . . . . . . . . 16

2.2 Parte I . . . . . . . . . . . . . . . . . . . . . . . . . . 19

2.2 .1 A Flor .................... 19

2.2 .2 A Máquina . . . . . . . . . . . . . . 21

2.3 Interlúdio . . . . . . . . . . . . . . . . 22

2.4 Parte II . . . . . . . . . . . . . . . . . . . . . . . . . . . . . . . 23

2.5 Enunciação e Tensão . . . . . . . . . . . . . . . . . . . 24

3 A Fantasia das Coisas de Todo Dia: Análise de um Filme Publicitário do Site Submarino $\quad 26$

3.1 Três Componentes de Análise . . . . . . . . . . . . . . . 27

3.2 Expressão Linguística . . . . . . . . . . . . . . . . . . . . . . 30

3.3 Música . . . . . . . . . . . . . . . . . . 32

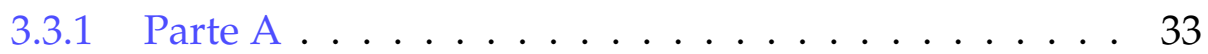

3.3 .2 Parte B ..................... 34

3.3 .3 Volta à Parte $\mathrm{A} \ldots \ldots . . \ldots 36$

3.4 Componentes Gráficos . . . . . . . . . . . . . . . 36 
3.5 Aspectos Tensivos . . . . . . . . . . . . . . . . . . . . 38

3.6 Semissimbolismo e Tensividade nos Três Componentes do Anúncio . . . . . . . . . . . . . . . . . . . . . . . . . . . 39

4 A Enunciação de um Valor: Análise de um Filme Publicitário da Cerveja Guinness

4.1 Enunciação e Metalinguagem . . . . . . . . . . . . . . . . . 42

4.2 Um Valor a Ser Construído . . . . . . . . . . . . . . . . . . 42

4.3 Um Outro Valor — a Captação do Texto-base . . . . . . . . . 44

4.4 Construindo um Objeto . . . . . . . . . . . . . . . . . 44

4.5 O Caminho do Sujeito . . . . . . . . . . . . . . . . 49

4.6 O Componente Musical e a Divisão do Texto . . . . . . . . . 51

4.7 A Sanção Estética . . . . . . . . . . . . . . . . . . . . . . 52

4.8 A Volta à Ordem . . . . . . . . . . . . . . . . . . . . . . 53

5 Do Icônico ao Simbólico: Estratégias para a Construção do Sentido

5.1 Da Natureza à Cultura . . . . . . . . . . . . . . . . . . . . . 58

5.2 Andamento e Saber . . . . . . . . . . . . . . . . . . . . . . 59

5.3 Na Publicidade . . . . . . . . . . . . . . . . . . 60

5.4 Contribuições da Figuratividade . . . . . . . . . . . . . 62

5.5 Interação entre Expressão e Conteúdo . . . . . . . . . . . . . 64

5.6 Minimalismo e Impacto . . . . . . . . . . . . . . . . . . 69

6 Algumas Constantes da Semiótica dos Anúncios Publicitários $\quad \mathbf{7 1}$

6.1 A Música . . . . . . . . . . . . . . . . . . . . . . . . . 72

6.2 A Câmera . . . . . . . . . . . . . . . . . 76

6.3 O Papel da Repetição . . . . . . . . . . . . . . . . . . . . 79

6.4 Estrutura de Clímax . . . . . . . . . . . . . . . 88

$\begin{array}{lll}7 & \text { Conclusão } & 97\end{array}$

$\begin{array}{ll}\text { Referências } & 105\end{array}$ 


\section{Lista de Figuras}

1.1 Bochechas Amarelas . . . . . . . . . . . . . . . . 9

1.2 Bolo Vermelho . . . . . . . . . . . . . . . . . . . . . 10

1.3 Bochechas Vermelhas . . . . . . . . . . . . . . . . 10

2.1 Sequência de close ups . . . . . . . . . . . . . . . . . . . . 17

2.2 Pas dutout ....................... 17

2.3 Violences conjugales . . . . . . . . . . . . . . . 18

2.4 Réagissons. . . . . . . . . . . . . . . . . . . . . . . . . . . . . . . 18

2.5 Ministère de la Justice . . . . . . . . . . . . . . . . . . . 19

3.1 E se existisse . . . . . . . . . . . . . 27

3.2 Filtro solar em comprimidos . . . . . . . . . . . . . . 28

3.3 Sapatos de sapateado para cachorro . . . . . . . . . . . . . 28

3.4 Você compraria? A gente venderia. . . . . . . . . . . . . . 29

3.5 Submarino . . . . . . . . . . . . . . . 30

3.6 Jornal que não voa na praia . . . . . . . . . . . . . . . 32

3.7 Parte A . . . . . . . . . . . . . . . . . . . . . . . . . . . .

3.8 Parte B . . . . . . . . . . . . . . . . 35

3.9 Volta à Parte A . . . . . . . . . . . . . . . 36

4.1 Primeira sanção . . . . . . . . . . . . . . . . . . . . . . . . . . 45

4.2 Segunda sanção . . . . . . . . . . . . . . . . . . . . 46

4.3 Trio de copos . . . . . . . . . . . . . . . 53

5.1 Três Sapos . . . . . . . . . . . . . . . . . . . . . 64

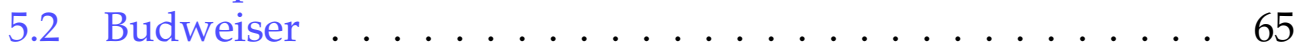




\section{Sobre o CD de Vídeo}

Um CD de dados acompanha este volume. O CD contém os quatro anúncios publicitários que foram analisados nesta dissertação. Os nomes dos arquivos foram escolhidos e listados na ordem em que suas análises são incluídas na dissertação:

- a_ministerio_de_justica_frances.avi

- b_submarino.wmv

- c_guinness.wmv

- d_budweiser.flv

Além desses arquivos, outros dois foram incluídos. O primeiro é um programa para leitura de vídeos de extensão .flv, que deve ser instalado caso não se possa abrir o último dos vídeos. Seu nome é:

- flv_player.exe

O segundo é um arquivo de áudio que é mencionado na análise do anúncio do Submarino:

- basesubmarinomidi.MID

A fim de facilitar consultas a notas de rodapé e referências bibliográficas, foi também incluída no CD uma cópia desta dissertação em formato .pdf com hiperlinks que levam o leitor às notas e referências. $\mathrm{O}$ arquivo recebe o seguinte nome:

- expressaoconteudo.pdf 
Assim como falham as palavras quando querem exprimir qualquer pensamento, Assim falham os pensamentos quando querem exprimir qualquer realidade, Mas, como a realidade pensada não é a dita mas a pensada.

Assim a mesma dita realidade existe, não o ser pensada.

Assim tudo o que existe, simplesmente existe.

Alberto Caeiro 


\section{Capítulo 1}

\section{Introdução}

O signo linguístico é, pois, uma entidade psíquica de duas faces [...]

Esses dois elementos estão intimamente unidos e um reclama o outro.

Ferdinand de Saussure 
As ciências da linguagem atualmente têm buscado uma compreensão ampla da linguagem, entendida como faculdade cognitiva, isto é, integrando aspectos como a percepção, o raciocínio e as representações de formas sincréticas (de mais de uma dimensão expressiva). Esse é precisamente o cenário teórico em que se desenvolveu a semiótica desde Hjelmslev, ao postular o estudo das associações entre expressão e conteúdo, aplicáveis de maneira universal a qualquer tipo de sistema de significação.

Esta pesquisa se propõe justamente a analisar textos sincréticos que sejam compostos de planos da expressão de substância verbal e visual. Para tanto, recorremos aos filmes publicitários, uma vez que, além de fornecer rico material para a análise das relações entre plano da expressão e plano do conteúdo, têm se tornado cada vez mais acessíveis, conforme será detalhado nos comentários acerca do estabelecimento do nosso objeto de estudo.

A pesquisa insere-se no quadro teórico da semiótica de linha francesa e, em particular, segue os recentes desenvolvimentos da semiótica tensiva. Em meio aos estudos de objetos sincréticos, abordaremos as relações que podem ser estabelecidas entre a expressão e o conteúdo desses textos. É possível encontrar muitos trabalhos em semiótica que se interessam pela composição do texto verbal com o texto visual, que tocam em especial nas questões semissimbólicas, como por exemplo alguns trabalhos de Floch (1985) e trabalhos sobre cartazes e filmes publicitários em geral. Entretanto, não se pode dizer o mesmo acerca dos trabalhos realizados no quadro dos estudos empreendidos na linha de Claude Zilberberg, que têm sido mais extensamente aplicados às áreas de literatura e música popular. ${ }^{1}$ É por esse viés que procuramos trazer uma outra luz aos estudos de semiótica sincrética. Procuraremos abordar, assim, as relações tensivas que podem estar por trás das categorias semissimbólicas ou, de maneira geral, que podem estar na base da ligação entre expressão e conteúdo dos textos sincréticos aqui sob análise.

Em vista das contribuições trazidas pelas propostas de Claude Zilberberg, acreditamos que sua aplicação a um número maior de objetos deve levar a esclarecimentos sobre os meios semióticos pelos quais se dá essa

\footnotetext{
${ }^{1}$ Jacques Fontanille, um dos pesquisadores que colaboram no desenvolvimento da corrente tensiva, escreveu recentemente um artigo acerca dos cartazes publicitários. Esse trabalho, entretanto, não traz uma análise muito minuciosa dos aspectos tensivos da publicidade (Fontanille, 2004).
} 
relação entre expressão e conteúdo. Nesse sentido, esta pesquisa se insere no centro das discussões atuais ligadas a essa dicotomia hjelmsleviana.

Os objetivos gerais destas investigações abarcam: (i) a proposta de estender os estudos da relativamente nova semiótica tensiva a novos objetos; e, inversamente, (ii) a perspectiva de que uma nova abordagem tensiva possa trazer luz a questões já consagradas no campo da semiótica, nesse caso, à relação entre expressão e conteúdo.

Como objetivos específicos, analisaremos filmes publicitários de tipos variados, com o intuito de explicar (i) de que forma a tensividade está presente nas categorias semissimbólicas; (ii) como o instrumental teórico da semiótica tensiva poderia ser aplicado tanto a categorias do conteúdo quanto a categorias da expressão; (iii) quais elementos da expressão seriam relevantes na composição da cifra tensiva no caso das propagandas televisivas; e (iv) como se pode partir diretamente de figuras da expressão e do conteúdo para a análise tensiva, sem que seja necessário fazer uso das categorias semissimbólicas.

\subsection{A Escolha de um Objeto}

Propusemos acima tomar como objeto de estudo textos sincréticos. A opção por esses textos traz, como dizíamos, além da ampla acessibilidade (via Internet, por exemplo), também questões interessantes para o estudo do semissimbolismo, uma vez que a multiplicidade de dimensões expressivas nos obriga a considerar quais seriam os elementos da expressão a serem levados em conta na análise. Procuraremos estabelecer brevemente o que deve ser entendido como objeto sincrético para os efeitos deste trabalho e os critérios que nortearam a escolha do corpus.

O sincretismo é um mecanismo que pode ser observado na homologação de dois elementos do plano da expressão (ou de elementos de dois planos da expressão de substâncias distintas — verbal e musical, verbal e visual, etc.) que geram a impressão de uma homogeneização do plano do conteúdo. Em outras palavras, as diferenças entre dois elementos do plano da expressão justapostos ou sobrepostos são suspensas e ambos parecem transmitir um mesmo sentido. ${ }^{2}$ Na semiótica, o sincretismo tomou outras

\footnotetext{
${ }^{2}$ As definições de sincretismo apresentadas por Hjelmslev (2003: 93 e ss.) e no primeiro tomo do dicionário de semiótica (Greimas \& Courtés, 1993 :374-375) são mais extensas.
} 
conotações que, de certa forma, se afastam da definição original de Louis Hjelmslev. A Semiótica greimasiana tratará de sincretismo de atores e actantes - mecanismo exclusivamente do plano do conteúdo - e, por um alargamento do termo, de semióticas sincréticas:

Num sentido mais largo, serão consideradas sincréticas as semióticas que - como a ópera e o cinema - colocam em funcionamento diversas linguagens de manifestação (tradução nossa). ${ }^{3}$

Nesses termos, encontraremos vislumbrada já no segundo dicionário de semiótica (Greimas \& Courtés, 1986) a possibilidade de analisar os objetos sincréticos como um "todo de significação":

Afirmamos assim a necessidade - e a possibilidade — de abordar esses objetos [sincréticos] como todos de significação e de proceder, num primeiro momento, à análise de seu plano do conteúdo. (tradução nossa) ${ }^{4}$

A proposta levantada no trecho citado era a de, uma vez que os objetos sincréticos formavam um todo de significação, passar diretamente para a análise do conteúdo. Desde então, a semiótica tem desenvolvido ferramentas para descrever também o plano da expressão e suas relações com o plano do conteúdo, como também para relacionar os diferentes planos da expressão de uma obra sincrética, como já anunciava o mesmo verbete da mesma obra:

É em função de um saber adquirido sobre os diferentes graus de correspondência e coextensividade entre essas unidades textuais e os sintagmas narrativos que se poderá retornar à manifestação e compreender melhor as regras de sua distribuição nas diferentes linguagens, bem como os papéis e estatutos que são

Hjelmslev (2003:93) menciona inclusive que o sincretismo pode ser verificado tanto no plano da expressão quanto no plano do conteúdo.

3 “En un sens plus large, seront considérées comme syncrétiques les sémiotiques qui — tels l'opéra ou le cinéma - mettent en oeuvre plusieurs langages de manifestation" (Greimas \& Courtés, 1993:374-375).

4 “On affirme ainsi la nécessité — et la possibilité — d'aborder ces objets comme des touts de signification et de procéder, dans un premier temps, à l'analyse de leur plan du contenu." (Floch, 1986:218) 
atribuídos a estes últimos; e que se poderá abordar o plano da expressão. (tradução nossa) ${ }^{5}$

Nesses termos, podemos dizer que neste trabalho não serão contempladas questões que digam diretamente respeito ao sincretismo enquanto conceito, isto é, não se trata de redefinir ou problematizar o sincretismo. Usaremos, na verdade, objetos sincréticos para desenvolver nossos estudos acerca das relações entre expressão e conteúdo. A escolha de semióticas sincréticas se justifica na medida em que esses objetos trazem questões para o semissimbolismo.

O trabalho de seleção do corpus teve início antes do nosso ingresso no programa de Pós-graduação, quando ainda estabelecíamos o objeto de pesquisa. Nesse período foram muito ricas nossas visitas a um site na Internet chamado Ad Awards (www.ad-awards.com). Tratava-se de um site que selecionava filmes publicitários de todo o mundo que fossem dignos de nota e atribuía-lhes premiações em diversas categorias. A importância dessa ferramenta foi enorme, uma vez que já fazia uma seleção prévia, trazendo acesso a um grande número de filmes, de temas e fontes variados e de alta qualidade. Com isso, foi possível selecionar um pequeno grupo de objetos bastante diferentes entre si.

Infelizmente, ainda no início da pesquisa, o site tornou-se inativo e, para conseguir os vídeos que ainda faltavam, foi preciso confiar na memória e nas buscas pela Internet. Foi assim que, num segundo momento, o site You Tube (www.youtube.com) tornou-se crucial. Foi possível encontrar aí alguns filmes que ainda não haviam sido baixados e outros novos. Os inconvenientes, entretanto, podem ser percebidos na qualidade da imagem, pois os arquivos são de ainda mais baixa definição, e na dificuldade de selecionar os vídeos, uma vez que não se trata mais de um site especializado.

Como dissemos acima, dentro da proposta de trabalhar com filmes publicitários, procuramos traçar um grupo bastante variado de objetos. Segue abaixo um detalhamento das especificidades de cada um:

\footnotetext{
${ }^{5}$ “C'est en fonction d'un savoir acquis sur les différents degrés de correspondance et de coextensivité entre ces unités textuelles et les syntagmes narratifs, qu'on pourra revenir sur la manifestation et mieux comprendre les règles de sa distribuition sur plusieurs langages, ainsi que les rôles et les statuts qui sont attribués à ces derniers; et que l'on pourra aborder le plan de l'expression." (Floch, 1986:218)
} 
a. Ministério da Justiça Francês: publicidade francesa. Esse foi o primeiro vídeo publicitário analisado e difere-se dos demais por ser um filme institucional/governamental. As publicidades tendem a manter um tom leve e euforizante, como de fato o fazem as demais. Mas o tema desse vídeo e seu destinador criam a possibilidade de um texto de tom grave.

b. Submarino: publicidade brasileira. Em contraste com o primeiro, este texto prima pela leveza. Trata-se de uma publicidade de um site de compras pela Internet. Não há referência a produtos (reais), apenas à empresa como um todo. Este foi o único filme que não foi obtido pelos sites mencionados acima, mas no próprio site da agência que criou o anúncio publicitário. ${ }^{6}$

c. Guinness: publicidade britânica. Nesse filme, chegamos ao produto - a conhecida cerveja irlandesa Guinness. A referência ao produto é direta, uma vez que a figura da cerveja aparece no início e ao final e integra a própria narrativa.

d. Budweiser: publicidade americana. Novamente encontramos um filme sobre cerveja. Entretanto, esse texto é ambíguo entre uma publicidade de produto ou de empresa. Não há referência direta à cerveja que não seja pelo nome. É um filme que se tornou clássico no meio publicitário e que explora amplamente um dos preceitos da publicidade que é a fixação da marca.

\subsection{Do Semissimbolismo à Tensividade}

Um dos mecanismos desenvolvidos pela semiótica para a análise dos textos sincréticos, talvez o mais difundido, é o semissimbolismo (Greimas \& Courtés, 1986: 203 e ss.). Na prática, isso representa a busca de correlações entre categorias relevantes do plano da expressão e do plano do conteúdo, dessa forma contemplando mais detidamente os discursos poéticos e nãoverbais. O mecanismo está ilustrado no famoso exemplo do discurso gestual em que se usa o movimento vertical de cabeça para afirmar e o movimento horizontal para negar (Greimas \& Courtés, 1986:204). Assim, teríamos a seguinte relação:

\footnotetext{
${ }^{6}$ Agência Giovanni, FCB 〈www.giovannifcb.com 〉. Última consulta em janeiro de 2007.
} 
verticalidade : horizontalidade : : afirmação : negação

A partir do exemplo citado, é possível notar que não há nenhuma relação necessária entre essas duas categorias. Trata-se de uma relação que se cria nesse contexto (do discurso gestual cotidiano) e se dissolve fora dele. Nada impede que num outro discurso a verticalidade esteja associada à negação, ou a um outro valor qualquer.

As relações semissimbólicas são necessariamente transitórias. No limite, isso se dá por força do imperativo saussuriano da arbitrariedade do signo (Saussure, 1997:81-84). Uma expressão não tem conteúdo, ela ganha conteúdo quando se faz signo. O "efeito semissimbólico" de que uma categoria independente do conteúdo corresponde necessariamente a uma categoria da expressão parece desafiar a arbitrariedade do signo: parece contraditório procurar motivação na relação entre significante e significado. Precisamos, no entanto, lançar mão de mais uma dicotomia saussuriana para justificar o semissimbolismo nesse quadro teórico. É preciso também considerar a oposição língua e fala, mais tarde reexaminada por Émile Benveniste (1995:284 e ss.) no quadro de uma oposição entre língua e discurso.

Como lembra o linguista francês (Benveniste, 1995: 54 e ss.), a relação significado/significante é arbitrária por ser imotivada, mas, uma vez estabelecida culturalmente, essa relação é necessária. O que o semissimbolismo vai produzir é uma desconstrução dessa relação que se tornou necessária dentro de um dado sistema e incutir novos sentidos à categoria selecionada, criando a ilusão de que uma nova relação entre expressão e conteúdo gerada num texto é motivada - que aquela expressão deve necessariamente estar associada àquele conteúdo.

A relação semissimbólica é, como se disse, transitória. Essa característica preserva o princípio de arbitrariedade de Saussure. A ligação entre categorias terá sido função de uma escolha feita no discurso, na contingência do texto, e não altera definitivamente o sistema. ${ }^{7}$ Quando falamos de uma escolha no nível do discurso, sugerimos a presença de uma intencionalidade, da presença de um sujeito da enunciação (Benveniste 2006:82; Greimas \& Courtés 1993:190). De fato, é em ato que a enunciação manipula os elementos da expressão para torná-los (re)significantes, ou seja, para injetar,

\footnotetext{
${ }^{7}$ Essa qualidade transitória pode não ser permanente se a nova relação semissimbólica for repetida suficientemente para que entre no sistema da língua. Veremos em mais detalhes abaixo.
} 
no texto, novos sentidos ou reiterar os sentidos apreendidos no conteúdo. Nos termos de Louis Hjelmslev (2003:121 e ss.), cria-se uma semiótica conotativa.

Em Petites mythologies de l'oeil et de l'esprit, Jean-Marie Floch (1985:206207) retoma a distinção hjelmsleviana entre sistemas simbólicos — nos quais há conformidade entre os termos da expressão e os do conteúdo - e os sistemas semióticos — nos quais não há essa conformidade (Hjelmslev, 2003:115-118). Floch propõe então a formulação de sistemas semissimbólicos, em que há conformidade entre os planos da expressão e do conteúdo, mas essa conformidade se dá entre categorias e não mais de termo a termo. A partir dessa divisão, Diana L. P. de Barros (2008:29-31) vai especificar as aproximações e diferenças entre sistemas simbólicos e semissimbólicos. Em especial, a autora argumenta que os sistemas simbólicos são culturalmente determinados, enquanto os sistemas semissimbólicos vão pôr em xeque as relações fixadas pela cultura e reconstruir uma nova verdade a partir do interior do texto e criar outras formas de conhecer e sentir o mundo. Em seguida, a autora chama a atenção para o caráter gradual que existe entre os sistemas simbólicos e semissimbólicos, explicando que as relações semissimbólicas criam inovações, mas a repetição frequente de estratégias semissimbólicas pode levar a uma fixação cultural, de tal forma que aquilo que era antes visto como inovação passa então a ser visto como banal, como uma relação já esperada (Barros, 2008:34-37). Inversamente, podemos também supor que novos semissimbolismos podem não apenas se servir daquilo que é culturalmente determinado para reconstruí-lo, mas também guardar uma proximidade com as determinações culturais, permitindonos reconhecer a novidade ao mesmo tempo em que vemos preservada a relação cultural.

Um exemplo pode esclarecer este último ponto. Tomemos o livro Chapeuzinho Amarelo de Chico Buarque (1987), em especial as ilustrações de Donatella Berlendis que acompanharam as primeiras edições. ${ }^{8}$

O livro é uma paródia de Chapeuzinho Vermelho. Nessa nova versão, Chapeuzinho Amarelo vai vencer certos medos, até mesmo do lobo, e seu

\footnotetext{
${ }^{8} \mathrm{O}$ texto completo dessa análise está publicado na revista eletrônica CASA (Lemos, 2008), exceto pelas observações a respeito da dimensão tensiva, que são inéditas.
} 
amadurecimento vai se revelar na possibilidade de sair de casa e brincar há, portanto, uma inversão da história original, em que Chapeuzinho Vermelho aprendera a ter medo do lobo (Discini, 2004 :180-181). As ilustrações do livro Chapeuzinho Amarelo têm, em sua maioria, o fundo branco, com traços pretos finos fazendo o contorno das formas. Apenas um elemento ganha relevo pela intensidade do traço: os olhos de Chapeuzinho Amarelo. A isso, acrescenta-se, em geral, uma única cor. Assim, a segunda ilustração do livro 9 (figura 1.1 abaixo) traz Chapeuzinho Amarelo em branco e preto, com as bochechas amareladas e uma expressão amedrontada.

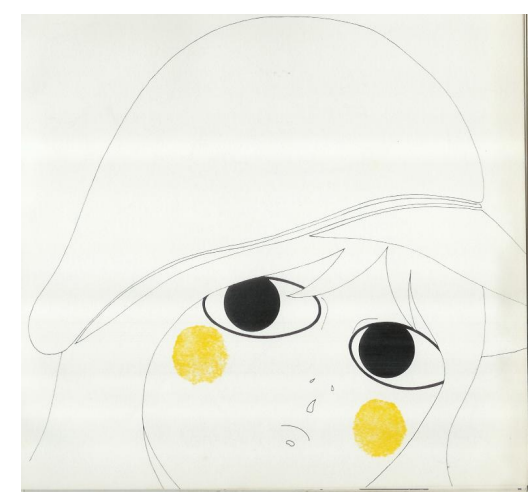

Figura 1.1: Bochechas Amarelas

O desenho começa a associar a cor amarela ao estado doentio e amedrontado da menina, como também o faz o texto ("Amarelada de medo [ ... ] Não estava resfriada /mas tossia"). Essa associação é naturalmente facilitada pelo conhecimento de mundo do leitor, uma vez que essa cor, em português, está ligada a esses estados (ao medo e às doenças). É possível associar o amarelo a doenças como o "amarelão" e a hepatite, e ao medo na expressão "amarelou" ("desistiu porque teve medo"). É assim que podemos exemplificar, como sugere Diana Barros, que o semissimbolismo retira figuras do estabelecimento cultural para formar os termos de suas categorias.

Como apontado acima, o uso do amarelo como figura do estado de alma de Chapeuzinho Amarelo é feito tanto no texto verbal quanto no pictórico. Entretanto, nas ilustrações, há uma passagem do amarelo (por vezes no rosto, em outras no chapéu da menina) para o vermelho (no bolo,

\footnotetext{
${ }^{9}$ A primeira ilustração é o desenho de um chapéu de aba amarela na página de rosto.
} 
na maçã e, finalmente, no rosto de Chapeuzinho), como se pode conferir nas seguintes figuras (1.2 e 1.3):

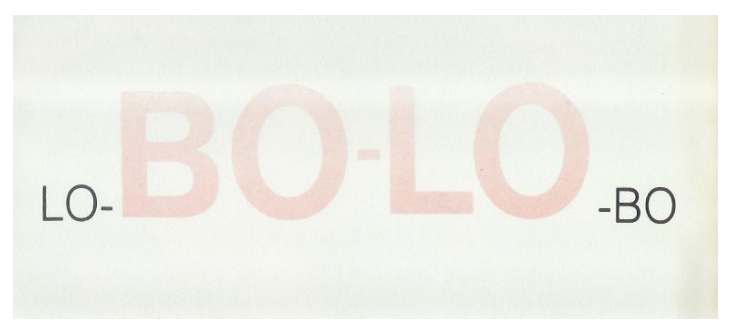

Figura 1.2: Bolo Vermelho

Essa mudança nas cores não se dá da mesma forma no texto verbal. Trata-se de uma estratégia da ilustradora para espelhar a transformação de Chapeuzinho Amarelo. O livro coloca, no início, a figura da menina de bochechas amarelas ao lado da descrição de seu estado amedrontado e doentio, mas insere um elemento vermelho quando a menina começa a vencer seu medo, culminando na figura da menina de bochechas vermelhas, já capaz de brincar, cair e levantar, e comer "de tudo, menos sola de sapato".

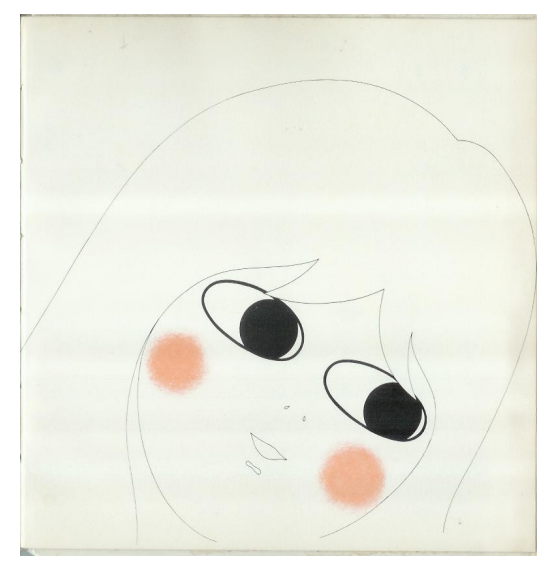

Figura 1.3: Bochechas Vermelhas

A combinação das cores e dos sentidos veiculados pelo texto nos permite propor um traço de "corporeidade" associado às cores. Assim, teremos uma falta de corporeidade, ou seja, um corpo mais doente ou debilitado na presença do amarelo, em oposição a uma forte corporeidade ligada ao vermelho, expressa no movimento, nas brincadeiras, nas novas atividades 
e no apetite da menina. É possível pensar nessa "corporeidade" de forma gradual: assim como temos uma maior concentração de cor na passagem do amarelo para o vermelho, temos uma intensificação correspondente na vivacidade da menina. Desse modo, paralelamente à substituição do amarelo pelo vermelho, são substituídas a doença pelo apetite, a estaticidade pelo movimento (brincadeiras) e a horizontalidade (estar sempre deitada) pela verticalidade ("trepa em árvore", "cai, levanta..."). O jogo de cores das ilustrações colabora, portanto, para reforçar o tema da transformação pelo amadurecimento.

$\mathrm{Na}$ análise do livro infantil, pudemos identificar o exemplo de uma categoria da expressão - escala de cor: vermelho $\times$ amarelo - homologada a uma categoria do conteúdo, que, nesse caso, escolhemos chamar de "corporeidade", a fim de abarcar as múltiplas figuras do estado de saúde da menina: estaticidade $\times$ mobilidade, doença $\times$ saúde, horizontalidade $\times$ verticalidade (todas oposições do conteúdo, nesse caso). Entretanto, o ponto que buscávamos levantar é o de que, apesar de a cor amarela ser emprestada de uma valoração social e de ela ser ressignificada nas novas oposições que se criam no texto, a cor em si não deixa de guardar sua conotação social convocada a todo tempo no texto. É nesse sentido, também, que o semissimbolismo pode estar colocado num meio de caminho entre aquilo que é fixado culturalmente e o que é francamente inovador.

Apesar da grande versatilidade que traz o semissimbolismo, as relações encontradas acabam por se revelar pouco justificadas na economia geral da análise do texto, pois são por demais acidentais e faltam elementos teóricos constantes que possam revelar o papel que essas categorias desempenham e como se ligam no interior do texto. Ou seja, é possível supor que possam ser propostas categorias mais abstratas, comuns à expressão e ao conteúdo, que se convertam em instrumental teórico e descritivo homogêneo para a análise de ambos os planos (Tatit, 2007a:18). Os sentidos incrementados pelo mecanismo semissimbólico podem atuar na economia geral do texto (Barros, 2008:33) e, portanto, pedem critérios de abordagem mais abrangentes.

Paralelamente aos desenvolvimentos da chamada teoria semiótica "padrão", surgiu, a partir da década de 1980, uma vertente que trazia propostas de desdobramentos do modelo, em especial para o nível fundamental: 
tratava-se da semiótica tensiva, inicialmente proposta por Claude Zilberberg com adesão posterior de Jacques Fontanille e de outros semioticistas. Os instrumentos propostos por essa linha trazem novas maneiras de relacionar entre si as categorias encontradas no plano da expressão e no plano do conteúdo. As categorias tensivas são bastante abstratas e vão justamente "temporalizar" as categorias semissimbólicas, ou seja, vão tratar esses opostos não mais como categóricos, mas antes como elementos de um termo complexo, dois elementos num contínuo do plano da expressão ou do conteúdo (Tatit, 2007a:28-38). Assim, a tensividade relaciona expressão e conteúdo "num patamar mais afastado da substância" (Barros, 2008:31).

Claude Zilberberg propõe relações extensas e intensas, fazeres emissivos e remissivos, espaços abertos e fechados num nível figural mais abstrato que os esquemas figurativos do nível discursivo (Zilberberg, 2006b:129 e ss.). $\mathrm{O}$ interesse dessas categorias tensivas é que, justamente por serem tão abstratas, não estão necessariamente ligadas ao conteúdo, como as categorias da semiótica dita padrão sempre estiveram. Na realidade, elas retomam critérios sonoros, acentuais e dinâmicos, normalmente associados ao significante linguístico, há muito abandonados pelos estudos semióticos. É o caso, por exemplo, da subvalência "musical" do andamento que nos permite verificar os movimentos de aceleração e desaceleração do texto (Tatit, 2007a:33-34). É por essa característica generalizante que as categorias tensivas se revelam tão adequadas a estabelecer a ligação entre expressão e conteúdo, a mesma que se reconhece no semissimbolismo. Se discutíamos que a diferença entre um sistema simbólico e um sistema semissimbólico é a de que naquele há uma relação termo a termo entre a expressão e o conteúdo, enquanto neste a relação se dá entre categorias, talvez seja plausível dizer que a semiótica tensiva oferece o termo complexo que subsume a categoria da expressão e a do conteúdo. Explicaremos no exemplo.

Se voltarmos às observações que fazíamos acerca de Chapeuzinho Amarelo, tínhamos as cores do lado da expressão e o estado de saúde da menina do lado do conteúdo:

amarelo : vermelho :: apatia : vivacidade

Dissemos que há, de um dos lados, uma relação entre os termos que associa a cor amarela ao estado de apatia, o que remete ao intertexto num sentido largo, nos valores fixados pelos incontáveis textos que formam uma cultura. Entretanto, no arranjo do texto, parece haver uma categoria 
mais geral que liga amarelo e apatia de um lado, vermelho e vivacidade de outro; uma espécie de "motivação" interna, uma qualidade que está presente tanto nas cores quanto no estado da garota. Quando doente, parece faltar a Chapeuzinho intensidade ou, mais particularmente, tonicidade: um querer forte, e não uma renúncia. Se, por outro lado, observarmos as cores escolhidas, veremos que a distância entre o vermelho e o amarelo também pode ser entendida como uma diferença de tonicidade, se considerarmos que a cor vermelha é mais tônica que o amarelo. Assim, na expressão como no conteúdo, temos o recrudescimento da subdimensão da tonicidade, que é o traço comum que nos faz entender a seleção feita nesse texto: amarelo, na mesma cultura a que está ligado esse livro, também pode simbolizar vida e calor, por meio de figuras como o sol, o mel, por exemplo. No entanto, pela ligação fundamental que se estabelece com o estado de alma da menina, pela sobredeterminação tensiva que as figuras dos dois planos da linguagem recebem, sabemos não ser eufórica a valoração dessa cor. "Amarelo" e "apatia" ocupam, cada um em seu plano, o mesmo lugar na economia geral do texto. A tonicidade, nesse exemplo, é o termo complexo que promove a ligação entre expressão e conteúdo. É a categoria complexa que faz perceber que dois termos são comparáveis, que estão em tensão (Tatit, 2007a: 40 e 49).

Da mesma forma como partimos, nesse exemplo que vimos desenvolvendo, de uma série de figuras do conteúdo que se ligam à categoria expressiva: estaticidade $\times$ mobilidade, doença $\times$ saúde, horizontalidade $x$ verticalidade e que dessas oposições chegamos a uma oposição mais geral como apatia $\times$ vivacidade para estabelecer a categoria do conteúdo que entra na relação semissimbólica, podemos também pensar que, se já contamos com a categoria tensiva abstrata que forma o nível figural, talvez não seja necessário que toda análise passe pela etapa de constituição dessa categoria intermediária. É possível imaginar um transporte direto das figuras da expressão e do conteúdo para as categorias tensivas. Um argumento nesse sentido é a constatação de que das palavras em estado de dicionário já podemos apreender uma dimensão tensiva. Para exemplos nesse sentido, podemos conferir o trabalho de Zilberberg (2008:5 e ss.) sobre os diferentes tons de rosa. A partir de um procedimento já difundido na semiótica, o autor procede a uma consulta a diversos dicionários da língua francesa para tomá-los como representantes do que está consagrado naquela cultura, seguindo daí para uma análise das tonicidades e temporalidades dos vários 
tons da cor rosa.

Por outro lado, a semiótica tensiva propõe uma forma de interação entre as dimensões e subdimensões de seu aparato metodológico (Zilberberg, 2007a:3-13), ou seja, quais os efeitos que cada subdimensão da intensidade tem sobre as subdimensões da extensidade e chega a dizer que a dimensão da intensidade "rege" a extensidade, afirmação que ainda está por ser desenvolvida. Dessa forma, mesmo que uma dada categoria da expressão diga respeito a uma subdimensão e a categoria do conteúdo a uma outra, é possível prever e analisar a interação dessas categorias de dentro do esquematismo tensivo. As análises propostas nas próximas seções deste trabalho trazem ilustrações variadas de uma aplicação possível dessa interação conforme aventado aqui.

A partir dessa discussão, voltamos à proposta de investigação apresentada acima. Somamos às propostas iniciais a observação de que as relações semissimbólicas entre expressão e conteúdo não atingem apenas localmente o texto, mas podem entrar no cômputo geral da cifra tensiva do texto. Vimos ainda que a tensividade pode ser apreendida a partir das figuras do nível discursivo e das figuras da expressão. Partimos agora para as análises que compõem o objeto deste estudo, a fim de desenvolver os argumentos que nos levarão às formas de interação entre expressão e conteúdo mediadas pelo aparato tensivo. As observações acerca dos mecanismos de interação entre os dois planos da linguagem trarão consigo generalizações sobre a estrutura interna dos filmes publicitários, tanto em seu conteúdo quanto em sua expressão. Em nossos capítulos finais, retomaremos esses pontos em aberto, à luz das análises desenvolvidas, para apontar quais são essas generalizações e de que forma interagem expressão e conteúdo nos anúncios publicitários. 


\section{Capítulo 2}

\section{Cognição e Paixão numa Publicidade do Ministério da Justiça Francês}

But thy eternal summer shall not fade, Nor lose possession of that fair thou ow'st

Nor shall Death brag thou wander'st in his shade, When in eternal lines to time thou grow'st So long as men can breathe or eyes can see So long lives this, and this gives life to thee. 


\subsection{Valores na Publicidade Institucional}

Ao apresentar um produto cuja aquisição é sempre, em última análise, facultada ao enunciatário, a publicidade precisa veicular valores de uso local e de proveito duvidoso: por que comprar o produto $x$ ? Por que agir como o anúncio sugere? Para que o enunciatário se interesse por esses valores, uma estratégia comum é incluí-los entre valores mais amplos e já consolidados, o que funciona graças à garantia de reconhecimento dos novos valores entre outros mais bem estabelecidos do ponto de vista sóciohistórico e, também, pela segurança característica do compartilhamento de valores entre o enunciador e o enunciatário. Assim, se esses novos valores são apresentados por marcas novas, preços novos ou, mais amplamente, informações novas, essas informações têm que permitir o reconhecimento por parte do enunciatário dos velhos valores, em que ele sempre costuma confiar. Por exemplo, nas publicidades de sabonetes com mulheres bonitas, o sabonete entra fazendo parte do universo da beleza; seu valor próprio é apagado em favor de um mais abrangente e mais seguramente desejável. A prova disso é que quem não se interessar por beleza, sensualidade, etc. não vai comprar o sabonete.

Um dos recursos da publicidade para tanto é produzir trocas entre os tipos de valor — valor prático, estético, etc. (Floch, 1998:409). No caso do sabonete, o valor prático é trocado por um estético; no caso do anúncio publicitário sob análise, o valor estético é que será trocado pelo prático, porque o primeiro se degrada rapidamente (a personagem do filme vai logo se tornando feia) em favor do segundo, que passa ao primeiro plano. $\mathrm{E}$ as informações novas que o enunciatário recebe, que causam surpresa e frustração de expectativas (na gradativa deterioração), compensam-no ao levá-lo rapidamente a valores compartilhados por ele: é preciso defender a mulher e a família, etc.

A peça publicitária mencionada, objeto desta análise, foi veiculada no ano de 2005 pelo Ministério da Justiça francês numa campanha contra a violência doméstica ${ }^{1}$. Na peça televisiva, vê-se o rosto de uma mulher jovem em close up, onde machucados vão aparecendo, sucessiva e cumulativamente. Ao lado de cada nova ferida aparece uma inscrição - como

\footnotetext{
${ }^{1}$ A peça publicitária foi obtida via Internet pelo endereço: < www.adawards.com/inc/video.swf?id=110 $>-$ vide $\mathrm{CD}$ anexo: arquivo “a_ministerio_de_justica_frances.avi".
} 
uma legenda - que em seguida desaparece para dar lugar à seguinte. As imagens são apresentadas nesta ordem: ${ }^{2}$

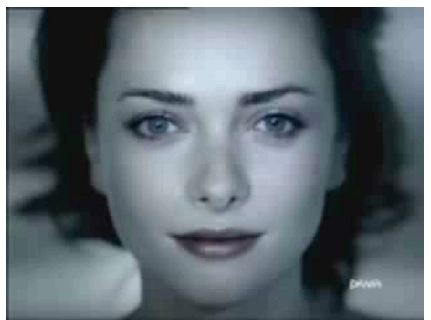

(a) Abertura

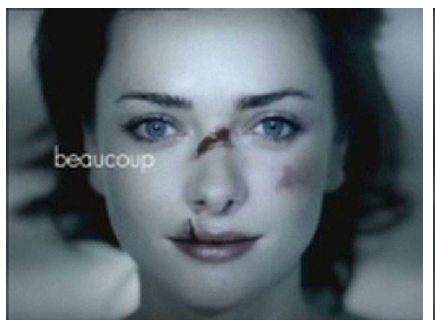

(d) beaucoup

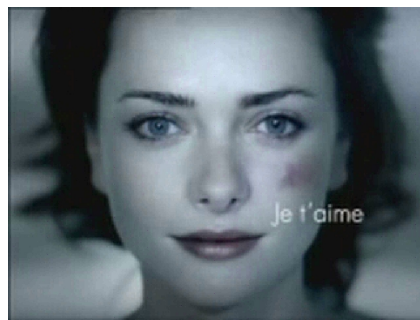

(b) je t'aime

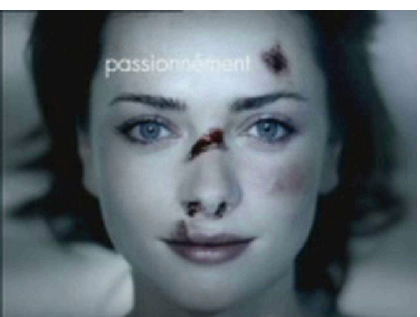

(e) passionnément

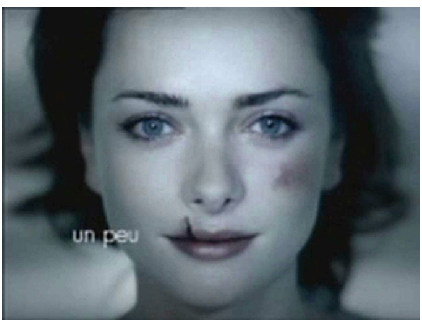

(c) un peu

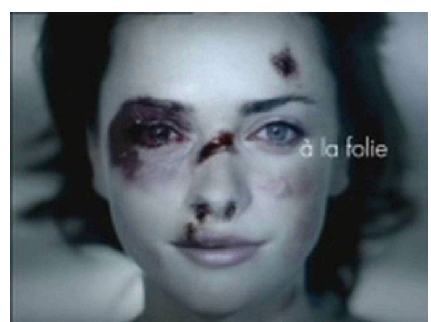

(f) á la folie

Figura 2.1: Sequência de close ups

Na cena seguinte, passa-se ao plano de conjunto, em que uma câmera no teto mostra a moça numa maca e um médico (ou algum outro profissional da área de saúde) que lhe cobre o rosto. Ao mesmo tempo, uma última inscrição aparece - agora no meio da tela: pas du tout (nem um pouco).

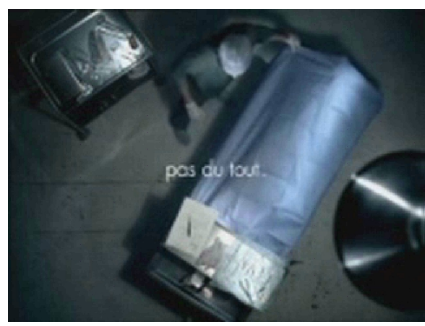

Figura 2.2: Pas $d u$ tout

Enquanto o médico continua com suas atividades de "encerramento",

\footnotetext{
${ }^{2}$ As traduções das "etiquetas" que aparecem na tela são, respectivamente, (a) "eu te amo"; (b) "um pouco"; (c) "muito"; (d) "apaixonadamente"; (e) "loucamente".
} 
duas últimas frases aparecem, contribuindo para o sentido global em dois movimentos diferentes daquele que vinha sendo construído na primeira parte, conforme será desenvolvido mais abaixo.

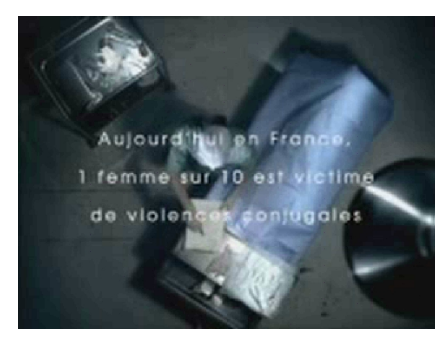

Figura 2.3: Violences conjugales

Na tela, lê-se:

Aujourd'hui en France,

1 femme sur 10 est victime

de violences conjugales ${ }^{3}$

E em seguida:

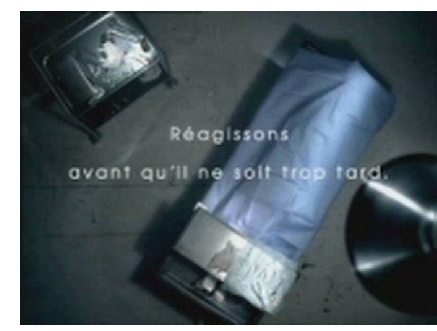

Figura 2.4: Réagissons

Na tela, lê-se:

Réagissons

avant qu'il ne soit trop tard ${ }^{4}$

Por fim, desaparece a cena do "hospital/necrotério", para dar lugar a uma tela clara e sem profundidade com as informações necessárias para contatar o Ministério da Justiça.

\footnotetext{
${ }^{3}$ Hoje na França, uma em cada dez mulheres é vítima de violência doméstica.

${ }^{4}$ Vamos reagir antes que seja tarde demais.
} 


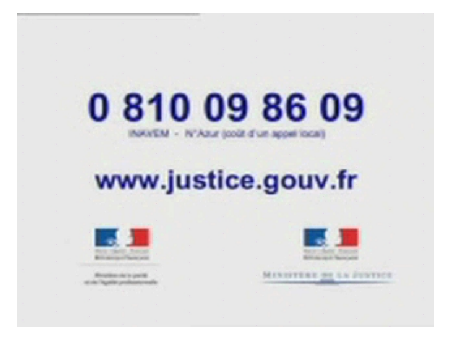

Figura 2.5: Ministère de la Justice

Nessa breve descrição, já ficam claros dois momentos distintos no desenrolar do filme: seja pelos dois planos de filmagem mencionados, seja pela mudança no tom das palavras. Nas próximas seções, serão examinados os diversos componentes: musical, verbal e visual, para explicitar com mais clareza essa divisão de partes e os efeitos de sentido que se compõem no curso do anúncio.

\subsection{Parte I}

\subsubsection{A Flor}

Conforme descrito acima, ao lado do rosto, vemos aparecer a inscrição je t'aime (eu te amo), ao mesmo tempo em que aparece um hematoma na maçã esquerda do rosto. Somem as primeiras palavras e aparecem as seguintes ( un peu - um pouco) juntamente com um novo machucado. Assim, vão aparecendo e desaparecendo palavras, enquanto o rosto da personagem vai ficando cada vez mais machucado. Podemos perceber um aumento progressivo no acúmulo de lesões e na intensidade das palavras: eu te amo um pouco - muito - apaixonadamente - loucamente. O aumento gradativo dos ferimentos vai gerando uma expectativa de agravamento sucessivo, dando uma direção para a narrativa. Essa direção criada pela repetição e pelo acúmulo faz o enunciatário antever o fim - a progressão só se fará até um limite, em que os traumatismos serão irreversíveis (Lopes, 2002 : 251253). A iminência do fim aumenta a cada instante a tensão no texto. Nos termos de Zilberberg (2006a:45 e ss. e 2007a:22), temos um movimento de ascendência, mas não exatamente de restabelecimento - uma vez que já partimos de uma posição positiva - e sim de um recrudescimento. De uma ampliação (um pouco) entramos no recrudescimento (mais mais) da 
ação destrutiva e caminhamos para os excessos que ultrapassam os limites de uma escala de progressão.

De fato, logo após o desaparecimento das últimas palavras, há uma mudança de câmera. O enquadramento em close up é substituído por um plano de conjunto, em que a câmera está colocada no teto de uma sala de hospital (ou de um necrotério) e vemos imediatamente abaixo o corpo daquela mulher numa maca sendo coberto por um funcionário/médico.

O texto verbal do anúncio remete-nos a um jogo de bem-me-quer-mal-mequer, no qual, à medida que vão sendo arrancadas as pétalas de uma flor, recita-se o par de versos alternados conforme sugere o nome do jogo. Em francês, a cantilena não fica numa oscilação entre dois termos, mas vai num crescendo (Je t'aime - un peu - beaucoup - passionément - à la folie) até chegar ao fim da série com pas $d u$ tout, quando o jogo recomeça até que as pétalas acabem.

Nessa publicidade, faz-se uma analogia entre a mulher e a flor. Diversos traços em comum entre as duas figuras corroboram essa leitura. Primeiramente, há, como foi dito, as palavras que remetem ao jogo. Além disso, no plano da expressão, a forma de apresentação das palavras, em que o aparecimento de cada frase vai formando um círculo em volta do rosto, associa o rosto ao centro da flor, reforçando a referência ao jogo infantil. A passividade da moça, que não esboça reação nenhuma às agressões que sofre, é também paralela à imobilidade da flor. Se a moça está no lugar da flor, não é ela que brinca, mas ele - o sujeito "oculto" apreendido pelo fazer explicitado pelos seus resultados: os ferimentos. Nesse filme, o processo de machucar a moça é como arrancar as pétalas da flor. Na brincadeira como no anúncio, a cada machucado tira-se um pouco da vida da flor/mulher.

Nesse contexto, reinterpreta-se a agressão como o ato de arrancar as pétalas que, aos poucos, vai tirando a vida. Nesse estágio do filme, texto verbal e texto visual se combinam para construir a intensidade emocional. Os machucados vão se somando à mesma medida que o texto vai se tornando mais tenso. Pode-se afirmar que o texto verbal dará a qualidade ao texto visual, que se intensifica em quantidade, conforme será mais detalhado adiante. 


\subsubsection{A Máquina}

Outros elementos do plano visual e musical vão caminhar na mesma direção de imprimir uma intensificação passional. A câmera em close up e os olhos da mulher direcionados para o espectador marcam a debreagem enunciativa. Chamaremos essa escolha de filmagem de "câmera tímica", porque a proximidade em que se coloca o ator (a mulher) põe em relevo o estado passional do actante. $\mathrm{O}$ ator do enunciado não traz marcas de gestualidade atributiva que revelem suas "atitudes e estados interiores fundamentais" (Greimas, 1970 :71). A escolha de focalização da câmera faz as vezes da expressão facial ausente, especialmente se contrastada com a câmera distante que se afasta desses traços de sentido vinculados aos gestos faciais. A ausência de gestos atributivos no rosto do ator aponta para a passividade do actante, que no desenrolar da narrativa vai se revelando como objeto e não sujeito da ação. A leitura de uma debreagem enunciativa se confirma no texto verbal pelo uso da primeira pessoa do singular em (je t'aime).

A narratividade na peça não é mostrada pelo fazer, mas pelos sucessivos estados do objeto. O sujeito é depreendido por uma combinação do querer expresso no plano verbal e nas modificações observadas no objeto.

Ao aparecer e desaparecer da tela, o texto verbal "representa" o fazer. Ao associar-se uma parte do texto verbal a cada alteração no objeto explicita-se o fazer. $\mathrm{O}$ texto verbal recorta a continuidade dos machucados apresentando-os e rotulando-os, como se o fazer fosse efêmero, contrastando com a irreversibilidade dos machucados.

O ritmo lento também contribui para trazer à tona esse fazer "não mostrado", uma vez que ressalta cada etapa, cada resultado parcial da transformação em curso, contribuindo para a intensificação passional. $\mathrm{O}$ ritmo também é marcado pela música, que é dividida, da mesma forma, nessas duas etapas mencionadas acima. A música dessa primeira parte, especialmente se comparada com a música da segunda parte, tem um caráter rítmico muito pronunciado. Junto com as imagens, ela pulsa, marcando os diferentes estágios da transformação. Dessa forma, seu caráter rítmico colabora na intensificação passional. 


\subsection{Interlúdio}

Há nesse filme publicitário um certo mistério a se desvendar. De início, vemos apenas um rosto pacífico. Com o desenrolar do anúncio vamos entendendo o que se passa. Os elementos que trazem direção ao texto anunciam um fim, mas o verdadeiro entendimento só se dá quando passamos da dimensão passional para a dimensão cognitiva.

Essa passagem, como foi apontado acima, vai ser claramente calcada nas três superfícies de expressão do texto: verbal, musical e visual. A fase de entendimento marcará a passagem do texto metaforizado e particularizado para a revelação da mensagem abrangente e explícita da publicidade.

Na dimensão imagética, no auge da tensão, com a presença de ferimentos por todo o rosto da moça e uma clara mudança de cor (o rosto torna-se azul arroxeado), a câmera passa de um close up para um plano de conjunto. Com a mudança de câmera, passa-se de uma debreagem enunciativa interna a uma debreagem enunciva. O novo enquadramento, que distancia o enunciatário, revela a morte. Poderíamos chamar o novo enquadramento de "câmera cognitiva", em oposição à "câmera tímica" — como sugerimos chamar o primeiro enquadramento. $\mathrm{O}$ enunciatário estava antes envolvido emocionalmente e com uma expectativa crescente. Nesse momento ele é distanciado e entende o que se passou.

O distanciamento revela elementos antes ausentes. Há uma descontinuidade entre um enquadramento e outro: some um aparece o outro. A câmera mantém o mesmo ângulo (diretamente acima da imagem), produzindo uma sensação de zoom out, o que acentua a impressão de que aquilo que se vê num segundo momento já estava lá na primeira parte, apenas não revelado. Assim, vê-se um ambiente de necrotério/sala cirúrgica. Ao cobrir o rosto da moça, o funcionário realiza o gesto estereotipado que encerra as expectativas e encerra a narrativa principal. A outra narrativa é aquela em que o enunciatário desta aparece como destinatário já sendo manipulado, instado a agir (Réagissons).

Ao lado dessas imagens, o texto verbal também chegará ao fim. A sequência de qualificadores que iam se intensificando passo a passo faz como que um círculo e cai num zero, uma vez que, seguindo o mais intenso dos modificadores: à la folie (onde seria possível dizer que há maior concentração de "amor"), aparecerá o pas du tout (que marca a ausência do sentimento). Essas últimas palavras surgem justamente no momento em 
que acaba de se passar para o plano de conjunto em que se revela a morte da mulher.

No plano musical, o ritmo vinha sendo fortemente marcado, intensificando os efeitos dos demais planos. Com o andar do filme, começamos a perceber, entre as muitas batidas da música, a sugestão do toque de um medidor cardíaco. A bem dizer, a figura do medidor cardíaco só fica clara no momento da mudança de plano visual, quando a música toca uma nota sozinha e contínua como o som de um aparelho que não capta mais batimento nenhum. Nesse momento, é possível reinterpretar as batidas da música inicial como as batidas de um coração disfarçadas no meio das muitas notas. Trata-se portanto de um componente figurativo trazido pela música.

Assim, a nota solitária que acompanha as palavras pas $d u$ tout e o novo plano da câmera entram como mais um elemento revelador, reforçando o entendimento do enunciatário. Essa nota faz também a passagem para a segunda parte do filme ao se mesclar na segunda parte da música que vai ganhando forma.

\subsection{Parte II}

Como vimos, a segunda parte é marcada, no plano visual, pelo afastamento e por uma debreagem enunciva que trazem explicação e entendimento. No plano musical, o elemento rítmico dá lugar a um desenvolvimento mais melódico. A melodia mais "passional" casa com o tom da descoberta da morte - da disjunção anunciada, enfim, tornada real.

Paralelamente ao fazer do médico e à mudança na melodia, a debreagem enunciativa interna (je t'aime) da primeira parte passa para a debreagem enunciva de primeiro grau, informativa: "Hoje na França, uma em cada dez mulheres é vítima de violência conjugal". No entanto, o texto verbal volta a uma debreagem enunciativa, dessa vez dando voz ao narrador, não mais ao interlocutor do enunciado (Barros, 2001 :75), usando a primeira pessoa do plural. Essa saída e esse retorno não são gratuitos nem sem consequências. Ao sair do particular para o geral e voltar para a primeira pessoa do plural, o texto verbal engloba a todos e torna a ação um dever de todos. Ele clama à ação todas as mulheres, os vizinhos, os homens que batem nas mulheres e o Governo, ele próprio (que descobrimos então ser o 
enunciador-destinador).

De volta ao paralelo entre a mulher e a flor, foi possível notar que o texto verbal põe em relevo a passividade, mas justamente esse texto verbal apela para uma transformação da mulher de objeto em sujeito. Ao chamar: Réagissons, ele está principalmente se contrapondo à postura passiva (de objeto, portanto) da mulher.

Por outro lado, a respeito da relação enunciador/enunciatário, observase que toda publicidade coloca em relevo a função conativa da linguagem no seu objetivo de despertar uma certa ação do sujeito (em geral comprar um certo produto). O contrato fiduciário entre o destinador (empresa que vende) e o destinatário (espectador) não é, em geral, explicitado, com o risco de se perder a magia. Esse anúncio, ao contrário, pode explicitar abertamente a que vem. Trata-se de uma campanha do governo que portanto veicula valores consagrados, amplamente aceitos e defendidos por todos e que podem assim ser explicitados. $\mathrm{O}$ filme, contando com a empatia do espectador, realiza uma manipulação (fazer-fazer) por meio da atribuição de modalidades. Ao apresentar um caso particular para, em seguida, generalizá-lo ("uma em cada dez mulheres é vítima de violência doméstica"), o filme produz um /saber/. Na medida em que esses valores são compartilhados por toda a sociedade, o /saber/ da existência dessa conjuntura gera consequentemente um /dever/. O destinador Ministério da Justiça, revelado no último quadro, ao lado dos símbolos institucionais, forma de contato, etc., atribui a seu destinatário o / poder-fazer/.

\subsection{Enunciação e Tensão}

Ao final da análise, dois pontos sobressaem como centrais na construção do sentido do texto: de um lado, os percursos da enunciação no enredamento do enunciatário na trama da manipulação; de outro, a questão da quantidade e do acúmulo na construção do estado passional (envolvimento) do enunciatário.

A construção da cifra tensiva dessa peça publicitária passa por uma dimensão qualitativa e outra quantitativa. No desenvolvimento da análise da primeira parte, foram mencionados diferentes papéis realizados pelo texto verbal e visual. Na dimensão gráfica, tínhamos um acúmulo progressivo de machucados que, ao mesmo tempo em que recrudescia a tensão 
no agravamento da condição da moça, ou seja, acrescentava intensidade a um sentimento já presente, começava a construir um novo sentimento, a expectativa do fim. O texto verbal, numa combinação do plano da expressão com o plano do conteúdo, trazia qualidade ao crescimento quantitativo dos machucados. Ao aparecer e desaparecer, as palavras geravam descontinuidade no contínuo dos ferimentos. Por outro lado, as expressões de qualidade funcionavam como etiquetas que tonificavam os ferimentos, diferenciando-os. A composição de qualidade e quantidade nesse momento do texto foi a chave para o desencadeamento da leitura de tensão na peça.

Do lado da enunciação, foi possível observar que, ao usar uma debreagem enunciativa, o texto criou, conforme discutido, uma aproximação do enunciatário e um envolvimento passional. Ao passar a uma debreagem enunciva, o enunciatário entende a situação colocada e estende os sentimentos surgidos no caso particular (da primeira parte) às muitas situações possíveis colocadas pelo texto verbal. Ora, por trás desse jogo de sintaxe discursiva está a ideia de que não se pode sentir por muitos sem ter experimentado o sentimento por um. Em seguida, a volta à debreagem enunciativa não se dá mais num plano individual. Seguindo a expansão trazida pela debreagem enunciva, o último trecho instaura um eu coletivo ("nós"), em que todos estão implicados nas consequências possíveis aventadas na curta narrativa do início ("antes que seja tarde demais"). 


\section{Capítulo 3}

\section{A Fantasia das Coisas de Todo Dia: Análise de um Filme Publicitário do Site Submarino}




\subsection{Três Componentes de Análise}

Em 19 de maio de 2005, o site Submarino de vendas pela Internet ${ }^{1}$ passou a veicular nos cinemas de São Paulo e Rio de Janeiro um filme publicitário de um minuto de duração realizado pela agência Giovanni, FCB. ${ }^{2}$

O filme consiste numa longa frase que vai sendo apresentada em partes, paulatinamente. A frase inicia-se com os dizeres: "e se existisse", quebrado em duas partes - primeiro surge "e se", em seguida, "existisse".

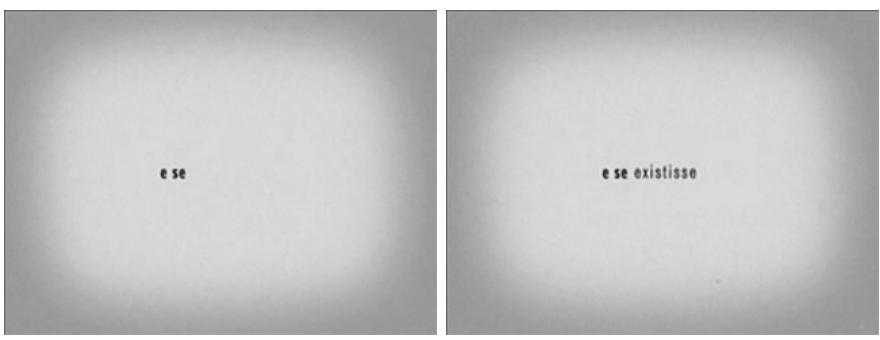

Figura 3.1: E se existisse

Ambas as partes somem para dar lugar à sequência da frase, que passa a ser uma fiada de muitos objetos inusitados. As letras, sempre com os mesmos caracteres tipográficos, surgem no centro do vídeo em letras minúsculas pretas sobre um fundo cinza. Após a abertura ("e se existisse"), que aparece em dois tempos antes de sumir, os objetos que serão apresentados virão em três partes. Na primeira fase, vemos o nome de um objeto surgir no centro, levemente deslocado para a esquerda; em seguida, um modificador desse nome surge à direita. Na terceira fase, as letras do modificador sofrem uma alteração gráfica de forma a tomar um aspecto mais gráfico do que textual e figurativizar a ação sugerida no texto. No fim dessa terceira fase, some esse objeto para dar lugar aos próximos que terão a mesma configuração, sempre sumindo para dar lugar a mais um novo objeto.

\footnotetext{
${ }^{1}\langle$ www.submarino.com.br $\rangle$

${ }^{2}\langle$ www.giovannifcb.com $\rangle$ - vide CD anexo: arquivo "b_submarino.wmv"
} 

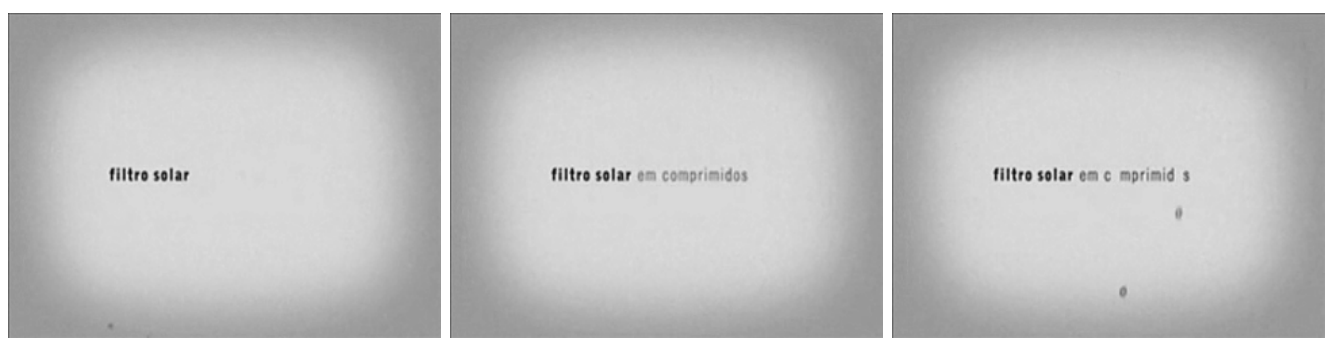

Figura 3.2: Filtro solar em comprimidos
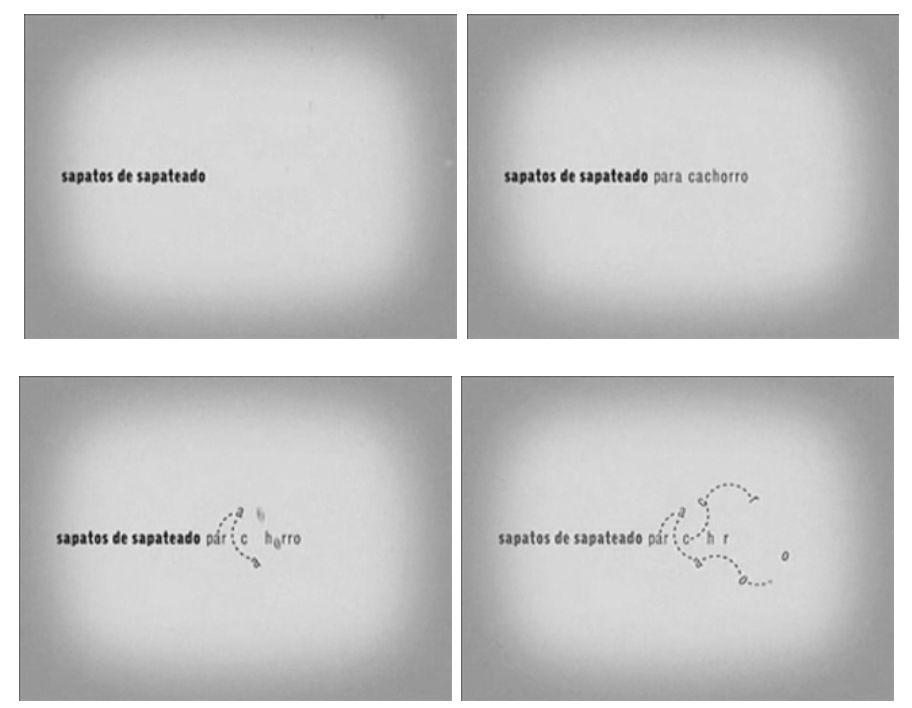

Figura 3.3: Sapatos de sapateado para cachorro

O componente visual do filme é formado exclusivamente por letras. Não há personagens filmados nem tampouco desenhados. Na ausência de personagens, os caracteres gráficos atorializam o texto. Também não há e este será o único anúncio que analisaremos com essa característica - mudanças no foco da câmera. As imagens são sempre apresentadas do mesmo ângulo, na mesma posição e com a mesma distância. A "ambientação" (ou o contexto visual) tem uma significação intertextual curiosa. O fundo cinza que já mencionamos não é uniforme. É mais claro ao centro e mais escuro nas bordas. Além disso, vemos a todo tempo pequenos riscos que aparecem e desaparecem rapidamente da tela, quase como se o negativo do filme estivesse danificado. As bordas queimadas e os "chuviscos" na tela fazem lembrar filmes antigos. 
Também a música, num piano eletrônico, se associada ao filme supostamente danificado, faz lembrar comédias antigas e estabelece, assim, nos elementos de ambientação, a primeira indicação do registro de leitura que vai permear o texto. Durante todo o desenrolar do filme a trilha sonora acompanha o desenvolvimento gráfico do texto, compondo-se com o ritmo, com a narrativa e com as figuras, conforme veremos adiante.

Após uma fiada de produtos fantásticos, a frase iniciada na primeira cena fecha-se na pergunta "Você compraria?", logo seguida da resposta "A gente venderia.", voltando à apresentação em dois tempos. No entanto, apresentação está agora levemente modificada. O primeiro termo some antes do surgimento do segundo. Isso está marcado sintaticamente, uma vez que as duas expressões não fazem parte da mesma frase. A primeira encerra a longa frase que teve início na abertura ("e se existisse..."), enquanto a segunda é uma resposta à pergunta que se formou. Está, dessa forma, bastante marcada a passagem para a resolução final do filme.

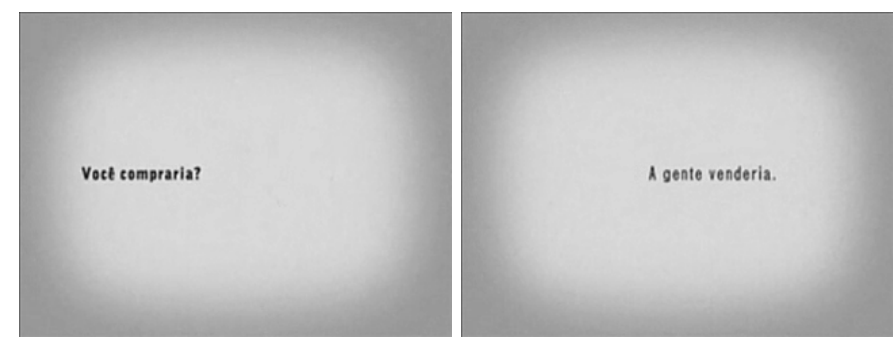

Figura 3.4: Você compraria? A gente venderia.

Por fim, somem as frases para dar lugar ao último quadro com o nome da empresa Submarino que, até então, não havia sido mencionada. Esta é a única palavra centralizada, apresentada num só tempo, com um outro tipo de letra e mais uma outra cor (azul) nas bolhas que lhe formam o logotipo. Embaixo do nome da empresa, formando com ele um todo, vemos o endereço do site. 


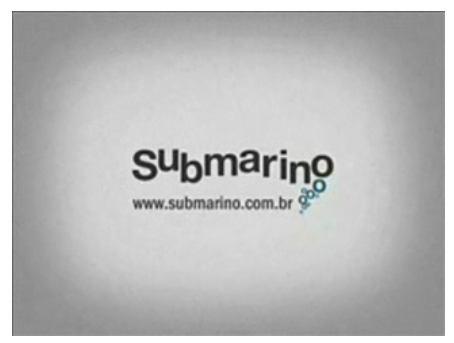

Figura 3.5: Submarino

Para a análise desse texto sincrético, propomos uma leitura detida dos diferentes componentes, de forma a encontrar as relações subjacentes que fazem com que três elementos distintos - texto, música e imagem formem um conjunto que veicula um sentido e estabelece um único contrato fiduciário com seu enunciatário, enfim, formam um único texto. Dessa maneira, analisaremos, em diferentes seções, cada um desses aspectos (a expressão linguística, a música e os componentes gráficos), sempre fazendo referência às outras seções, pois, uma vez que se trata de um único texto (em sentido amplo), como ficará claro no decorrer do estudo, a análise pura de um deles não se faz possível. O sentido de cada parte está tanto mais ressaltado quanto mais se confirma nos mecanismos das outras. Em seguida, faremos algumas observações acerca da dimensão tensiva que tece essas relações num plano profundo. Por fim, algumas observações finais tentarão pôr em evidência os efeitos que essa composição produz no enunciatário.

\subsection{Expressão Linguística}

O texto proposto nessa peça publicitária propõe um contrato fiduciário

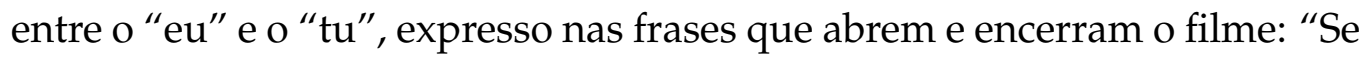
existisse... Você compraria? A gente venderia." Na verdade, o espectador só se dá conta da natureza contratual nas duas frases finais, o que traz ao anúncio publicitário um valor de descoberta, ou seja, o espectador vai, passo a passo, por meio da repetição dos elementos, percebendo para onde o texto o conduz. A revelação gradual, associada à apresentação de objetos novos e curiosos, garante um aspecto tentador à manipulação realizada para a criação do contrato fiduciário. 
Por outro lado, os objetos novos, inusitados apresentados no anúncio, além de corroborar a manipulação, também surgem como um objeto de valor a ser buscado. Dessa forma, a existência de objetos de valor e do querer-fazer, promovido pela manipulação, virtualizam um fazer, ou uma transformação virtual do sujeito que passa da disjunção para a conjunção virtual com o objeto ${ }^{3}$ - o que parece ser uma característica, aliás, de todo contrato de compra e venda. O caráter virtual da transformação está explícito na ausência de um fazer real, naturalmente, como também é marcado pelo condicional dos verbos e pela forma de pergunta em que o fazer é expresso ("você compraria?").

Assim, a publicidade propõe objetos inusitados que formam um conjunto heterogêneo. O que traz homogeneidade para esse conjunto é, antes de mais nada, a forma de expressão desses objetos. Esses objetos estão ligados pela música que compõe o vídeo e acompanha a apresentação dos elementos, como será desenvolvido mais adiante, mas também por elementos gráficos como a tipografia, a disposição na tela e a sequência em que as suas diferentes partes são apresentadas. Essas características, associadas ao conteúdo comum de serem - antes da introdução das segundas partes todos objetos cotidianos, formam uma identidade que criará uma isotopia figurativa.

A estratégia manipulativa aqui é interessante. Ao virtualizar todo tipo de objeto improvável e colocá-lo ao alcance do consumidor, o que se pretende é ostentar a realidade do poder pela virtualidade do ser: o enunciatário pode ter o que quer que seja, até mesmo o que virá a ser. Ademais, nem só a inexistência de tais objetos (e sua virtual existência) é importante. A heterogeneidade dos objetos citados é talvez mais fundamental do que sua virtualidade para os efeitos alcançados pelo texto. Ao remeter a objetos tão distanciados quanto filtro solar, sapatos, jornal, lente de contato, caderno escolar, fralda, etc., o enunciador parece querer alcançar todo o espaço figurativo da vida cotidiana do enunciatário, como se enumerasse todos os instrumentos práticos do dia-a-dia. Assim, se os objetos compostos são fantasiosos ("jornal que não voa na praia", "fralda com alarme", etc.), os objetos de base - isto é, sem a modificação que os torna fantasiosos - correspondem perfeitamente àquilo que se compra todo dia. Isso está

\footnotetext{
${ }^{3}$ No esquema canônico do quadrado semiótico, diríamos, mais precisamente, que se passa de uma disjunção para uma não-disjunção que, essa sim, se traduz numa conjunção virtual.
} 
claramente indicado na apresentação dos objetos, tanto pelo intervalo entre as partes - a parte "substantiva" aparece primeiro e a modificação depois - quanto pela incidência da animação que figurativiza a modificação, que só atua no modificador (por exemplo, já no segundo objeto, o "jornal que não voa na praia", a parte que "voa" é "que não voa na praia" — figura 3.6). Portanto, ao apresentar tais objetos de uso cotidiano ao enunciatário, o enunciador diz precisamente a que veio: vender objetos cotidianos, nem mais, nem menos.
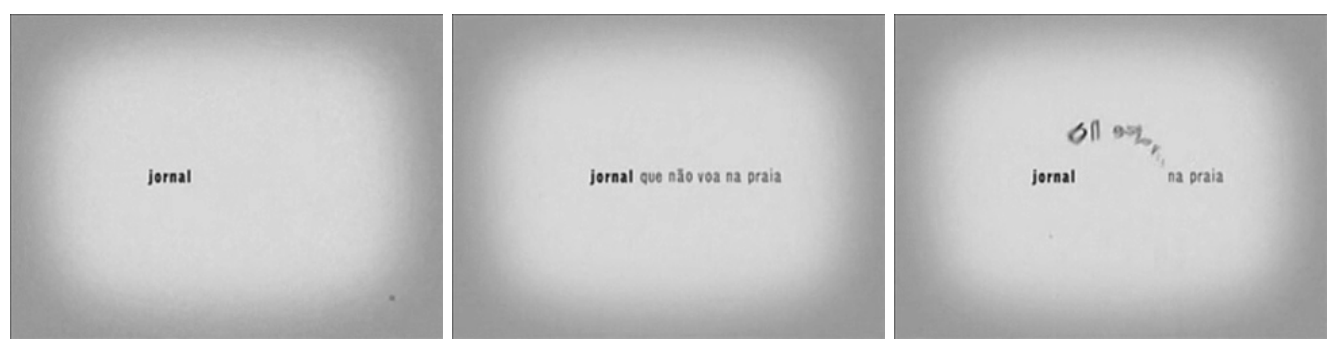

Figura 3.6: Jornal que não voa na praia

\subsection{Música}

A música usada no vídeo pode ser dividida em três partes, às quais chamaremos A-B-A, uma vez que é possível observar uma semelhança entre a primeira e a terceira parte, ainda que haja mudanças no arpejo. Além disso, percebe-se, na primeira parte, uma "introdução" no piano-base que consiste no motivo de $6 \times 2=12$ notas que funciona como elemento invariante (Hjelmslev, 2003:65-77) de toda a peça, como pode ser observado nas marcações feitas na figura 3.7 abaixo. ${ }^{4}$

\footnotetext{
${ }^{4}$ No CD em anexo, segue um arquivo MIDI entitulado "basesubmarinomidi.MID", onde está isolado apenas o piano-base e pode ser usado para acompanhar as figuras. Agradecemos a José Roberto do Carmo Jr. a gentileza e a paciência na geração desse arquivo.
} 


\subsubsection{Parte A}

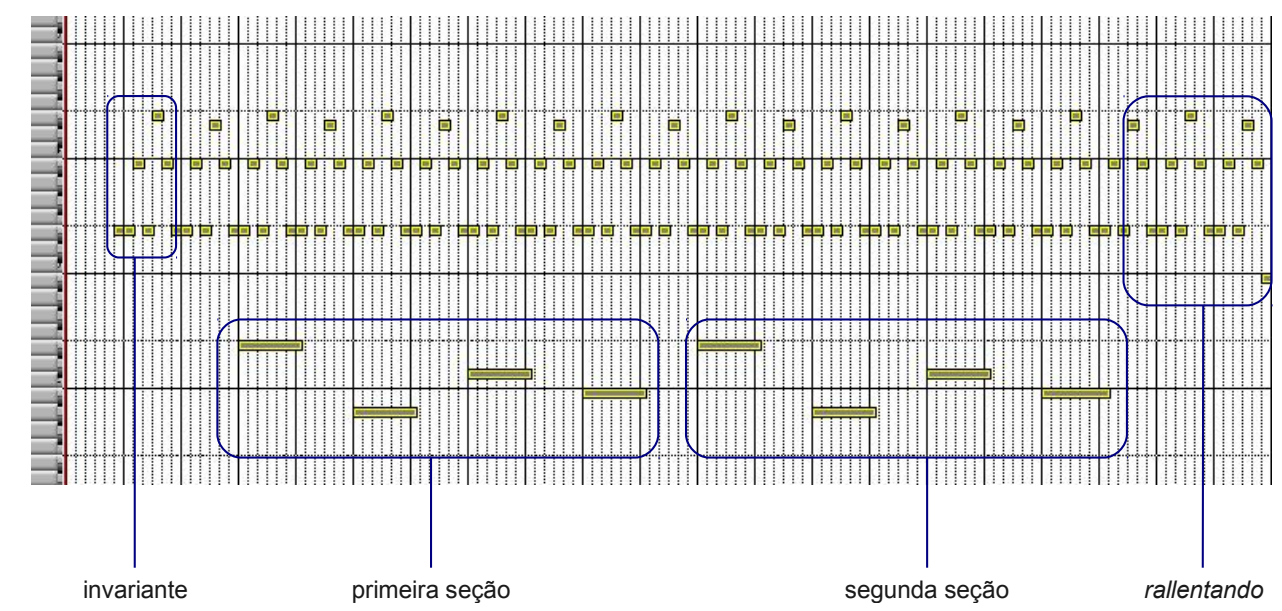

Figura 3.7: Parte A

A figura acima representa os sons produzidos pelo piano que faz a base da música no filme. À esquerda, vêm-se representadas as teclas de um piano, de tal forma que a parte superior do desenho corresponderia à mão direita do pianista, ou seja, os sons mais agudos. A parte inferior corresponde à mão esquerda do músico, ou os sons graves do piano. Partindo das teclas em direção à margem direita do papel temos um padrão quadriculado que representa no espaço o desenrolar do tempo. Assim, o primeiro ponto amarelo, mais à esquerda, será a primeira nota da música. À medida que se caminha no papel em direção à direita, aparecem-nos as notas seguintes. Dito de outra forma, se vemos marcas amarelas no mesmo eixo horizontal, temos que têm a mesma altura, se vemos marcas amarelas no mesmo eixo vertical, elas têm alturas diferentes (uma mais grave, outra mais aguda), mas são tocadas ao mesmo tempo. Imagine-se aí um pianista que pressiona muitas teclas de seu piano ao mesmo tempo (num acorde, por exemplo). Vale também observar que algumas notas (marcas amarelas) são como pontos e outras como traços. Isso se refere à duração da nota, ou seja, no ponto, temos uma nota breve, no traço, temos uma nota que dura.

Com o desenho acima em mente, podemos notar que a mão direita do 
pianista (os sons mais agudos) forma um arpejo que compõe a introdução da primeira parte musical. Essa parte introduz um cenário, um pano-defundo. $\mathrm{O}$ arpejo é a base sobre a qual os elementos centrais como o ritmo, o andamento e a escala melódica vão se desenvolver. Nesse momento, também o texto criará um cenário. A frase "e se existisse" problematiza e questiona existências, fazendo com que todos os objetos apresentados tenham uma existência virtualizada - da mesma forma que, como falamos acima, estão virtualizados na perspectiva narrativa os fazeres e os desejos do sujeito (enunciatário) no texto.

Logo em seguida, entram as notas graves (marcadas na figura 3.7 como "primeira seção" e "segunda seção"), que coincidem com os fragmentos de texto que vão surgindo no vídeo. Assim, a mão esquerda do piano-base introduz as figuras que aparecem no plano visual. Os graves vão formar um paradigma de alternância alto-baixo. O paradigma está consolidado nas quatro primeiras notas, mas já no primeiro par é possível perceber a alternância. No momento do reinício desse paradigma — das quatro notas longas e baixas - um contrabaixo começa a soar junto com a mão esquerda do piano, reforçando as expectativas e trazendo algumas outras notas graves para a base que se constrói. Percebemos, assim, todos os elementos da música criando muitas recorrências e trabalhando para confirmar exaustivamente as expectativas do enunciatário. Parece razoável afirmar também que tais recorrências embasam expressivamente um certo ar de familiaridade para o enunciatário, tornando mais palatável o conjunto, que no plano do conteúdo é carregado de surpresas.

Ao olharmos para o texto/imagem, percebemos - atentos apenas à mão esquerda do piano-base - que, a cada par de notas, a nota mais aguda coincide com a apresentação da primeira parte do objeto, e a mais grave com a da segunda parte.

\subsubsection{Parte B}

No fim da primeira repetição do paradigma das notas graves começa uma segunda parte, anunciada pelo rallentando (desaceleração) no fim da primeira parte (vide figura 3.7) e percebida pela leve alteração no motivo melódico e pelo registro mais grave já na segunda, conforme se vê no contraste da parte superior da figura $3.7 \mathrm{com}$ a parte superior da figura 3.8. 


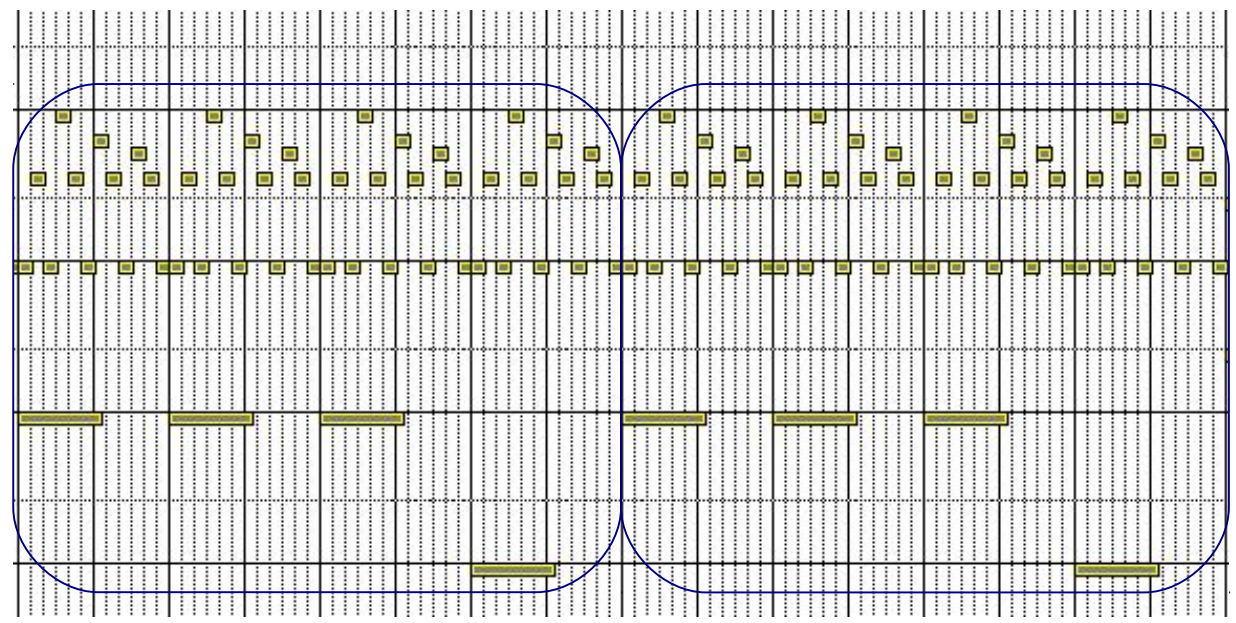

Figura 3.8: Parte $B$

Um dos padrões da música popular é aquele feito de uma primeira parte reconhecida como um refrão, uma segunda parte com modificações na música e na letra e uma volta para a primeira parte. Fazem parte desse tipo de canção as marchas de Carnaval, das quais a gente só lembra mesmo os refrãos... A música desse filme é feita com esse mesmo modelo. A primeira parte tem toda a regularidade que vimos acima. A segunda parte vem para desestabilizar levemente essa música "redondinha" e criar uma nova regularidade (Tatit, $1997: 24-25$ ).

Dizemos ser "leve" a desestabilização promovida na segunda parte. Isso porque a primeira e a segunda partes permanecem unidas por certos componentes dos paradigmas estabelecidos, tanto o visual quanto o musical. No plano musical temos vários elementos como o ritmo, o andamento, ou ainda o esquema de arpejo, as notas graves que duram e as vozes dos instrumentos, por exemplo, que garantem a identidade entre as partes. No plano visual, a unidade se mantém no esquema de apresentação das figuras, que continuam - na composição com o plano musical - a ser introduzidas pelas notas graves, nas escolhas tipográficas e nos ritmos de complemento e mudança do texto, que permanecem idênticos aos da parte inicial. 


\subsubsection{Volta à Parte $\mathrm{A}$}

No fim da parte B, percebemos uma pausa e em especial um acorde (Dó menor) fora do campo harmônico (Mi maior) que vinha se desenvolvendo até então. Essa nota gera tensão e a expectativa de uma nova mudança; na verdade, ela pede por uma solução. Este é o clímax do filme e, portanto, o começo do fim.

A música se resolve retornando ao início. Como no esquema da música popular, voltamos ao refrão - ao mesmo motivo (levemente alterado) e ao mesmo registro de altura da primeira parte, como pode ser observado na figura 3.9 abaixo. Resolve-se também o texto, cuja temática se desvela claramente, sob o mote "qualquer que seja o objeto, você pode tê-lo através do Submarino".

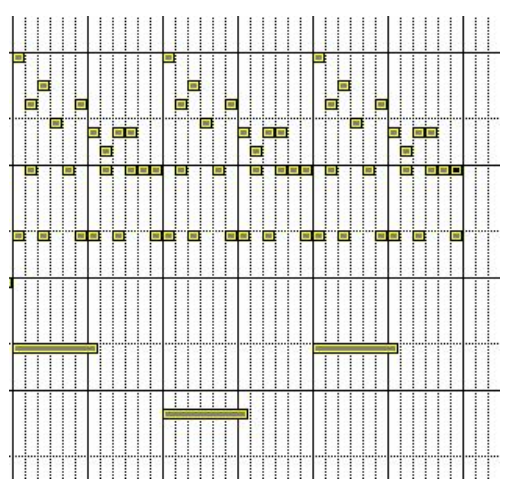

Figura 3.9: Volta à Parte $\mathrm{A}$

\subsection{Componentes Gráficos}

As figuras são apresentadas no tempo e no espaço de maneira a se compor sintaticamente. Cada parte da figura é apresentada, como mencionamos acima, pelo grave do piano, o que corresponde à apresentação do ator/actante.

A apresentação do objeto se dá em duas partes. Essa forma de apresentação, associada à qualidade dos elementos apresentados cria um efeito metafórico. Primeiro é apresentado o objeto, em seguida um modificador. A impropriedade da relação entre o modificador e o objeto causa um estranhamento e gera esse efeito de metáfora, como vemos, por exemplo, já no primeiro elemento. Primeiro, apresenta-se o "filtro solar" — objeto 
cotidiano sem mais interesse. Em seguida, aparecem ao lado as palavras "em comprimidos", que, tomadas isoladamente, também se mostram perfeitamente cotidianas. Mas a associação sintática desses dois objetos comuns cria um objeto inusitado. A impropriedade da relação é, como dito acima, o criador da metáfora (Lopes, 1987:9-10).

O percurso de cada objeto se dá em três partes: a apresentação, a modalização e a ação. Observemos o exemplo da "lente de contato" (quarto objeto apresentado). Na primeira nota grave, vemos surgir o objeto: lentes de contato. No segundo toque, surgem as palavras: "que somem quando você dorme". Note-se que a segunda parte traz a modalidade de um poderfazer acrescentada ao sujeito do qual o instrumento "faz parte". Assim, entendemos que o instrumento é, na verdade, parte do sujeito. Não cabe ao instrumento um papel de objeto de valor, uma vez que se trata não do objetivo final do sujeito, mas um meio para atingir um outro fim. No caso das lentes de contato que somem, temos um poder-não-fazer: um poder não tirar as lentes, não se preocupar com elas. Dessa forma, tratamos os objetos apresentados como um instrumento que soma uma nova modalidade ao sujeito.

Num terceiro momento, com todo o texto verbal já apresentado na tela, vemos que as letras das palavras da segunda metade "realizam" graficamente a ação sugerida pela modalização. Ou seja, ao criar um poder na segunda parte da apresentação, o texto verbal virtualiza um fazer. $\mathrm{Na}$ terceira parte, realça-se o aspecto gráfico do texto verbal, na medida em que as letras sofrem modificações que "imitam" a ação realizada pelo sujeito. De volta ao exemplo das lentes de contato, as palavras "que somem quando você dorme" vão gradualmente se esfumaçando e desaparecendo do vídeo como se as lentes de fato estivessem sumindo dentro dos olhos do sujeito.

Como vimos, a apresentação e a modalização são feitas pelos graves. Em seguida, o componente verbal é modificado, tendo sua função de imagem posta em relevo. Temos assim que o sujeito modalizado realiza a ação para a qual está preparado. Essa ação, apresentada no jogo/dança realizado pelas letras na tela, é marcada na música não pela base, que como vimos tem valor de cenário, mas pelo solo. Assim, vemos como a música dessa peça ganha contornos realmente figurativos. O piano-base introduziu um pano-de-fundo geral com o arpejo (que chamamos acima invariante) e a apresentação dos objetos e suas modalizações com as notas graves. O pianosolo, por outro lado, acompanha diretamente a ação. Música e imagem 
seguem num mesmo pulso para criar a figura da ação, como é possível perceber, por exemplo, na pulsação das lentes de contato desaparecendo ou no sobe e desce do cachorro que dança sapateado ("sapatos de sapateado para cachorro" - figura 3.3).

Temos então fazeres em duas dimensões. De um lado está o objeto considerado no todo do anúncio como objeto de valor para o consumidor. Esse fazer, como vimos, é virtualmente realizado no querer-fazer (querercomprar) do sujeito. De outro lado, cada item apresentado no filme tomará o papel de sujeito no âmbito particular, uma vez que esse objeto figurativiza parte da competência do sujeito, na forma de instrumento que traz modalidades para que realize uma ação.

\subsection{Aspectos Tensivos}

Em todas as suas dimensões, visual, verbal e musical, trata-se de uma peça com andamento rápido, no eixo da intensidade, e tempo breve, no eixo da extensidade. Sobre a música, percebemos uma tendência à concentração, pois tem uma base acelerada e uma tendência para a involução (Tatit, 1997 : 24): a melodia tende a se repetir e constantemente retornar em seu motivo para garantir o sentido do texto musical. Esses aspectos da música se compõem francamente com os demais elementos do texto. Paralela à pequena tessitura e à clara repetição do motivo, vemos a predominância de conjunções, ainda que virtuais, do sujeito com os seus objetos, sem forte presença de um antissujeito, sempre vislumbradas na terceira parte da apresentação de cada objeto, conforme desenvolvido na quarta parte deste trabalho. Assim, no texto como um todo predominam valores emissivos, de "passar". O antissujeito enfraquecido pode ser apenas vislumbrado na nota tensa da música, no desaparecimento das imagens no plano visual e na "irrealidade" dos objetos apresentados no plano verbal. Na falta quase absoluta de empecilhos, vemos um sujeito pró-tensivo, impelido a um objeto com forte poder de atração.

Por outro lado, é ainda possível explorar uma outra dimensão tensiva, que vai se construindo no desenrolar do vídeo. Dissemos que a peça se apresenta num andamento acelerado e num tempo breve, entretanto, a própria repetição exaustiva vai provocando uma saturação e aumentando a tensão do enunciatário frente à suspensão do entendimento (Zilberberg, 
2006b:132-133). O enunciatário foi, até então, exposto a uma série de objetos curiosos que não se deixam revelar em seu propósito: afinal, a que vêm todas essas coisas inusitadas?

O ápice da tensão se dá com a apresentação do último objeto ("fralda com alarme"), no plano textual. No musical, o último acorde está fora do desenvolvimento harmônico regular e percebemos um alongamento da duração das notas, há até mesmo uma parada - tanto no plano da expressão (em suas variadas dimensões: na música, na disposição gráfica e no arranjo sintático que vinha tomando o texto) como no plano do conteúdo.

Na sequência, resolve-se o texto: o mundo hipotético que foi criado no início ("e se existisse") se explica na pergunta e resposta: "Você compraria? A gente venderia." A apresentação do nome e logo da empresa Submarino fecha o "mistério" e traz reconhecimento ao enunciatário, que numa leitura reversa reconhece o novo contrato como uma confirmação de um contrato a que essa empresa desde sempre se propõe - reconhece-se o destinador. De seu lado, a música retorna ao esquema breve e acelerado que é a cifra tensiva de toda a peça. Essa última parte revela-se como a parada da parada.

Ao tomar essa configuração, a peça ganha a forma das narrativas tradicionais, na medida em que elas acompanham o percurso de um herói lançado ao desconhecido e que acaba por retornar ao conhecido - e, aliás, reconhecido, no momento da sanção.

\subsection{Semissimbolismo e Tensividade nos Três Com- ponentes do Anúncio}

Nesta análise procuramos apresentar como as diversas dimensões de um texto sincrético se compõem para a construção do sentido. Dessa forma, levantamos aspectos do conteúdo e contrastamos com aspectos da expressão, estudando as formas de correspondência recíproca entre eles. Em diversos momentos, foi possível notar relações especulares entre a forma da expressão e a forma do conteúdo. Assim, observamos, por exemplo, que o esquema de arpejo corresponde ao cenário criado no plano do conteúdo. As notas graves do piano-base apresentam os objetos modais. Ao piano-solo, por outro lado, associou-se o fazer. Também notamos que a apresentação gráfica do texto colocou em relevo o esquema narrativo canônico 
na distribuição sequenciada dos elementos, da modalização à ação.

Entretanto, para além dessas relações mais diretas, foi possível também investigar relações tensivas que demonstram uma composição mais intrincada das diferentes formas de expressão que veiculam os conteúdos dessa peça publicitária. Nesse sentido, localizamos uma cifra tensiva comum à música e ao componente verbal, por exemplo, mas também tentamos mostrar como, apesar de se tratar de um texto com um antissujeito por demais enfraquecido, há uma pequena alteração na cifra tensiva que vai se construir pelo excesso (Zilberberg, 2006a:45-46).

De maneira geral, temos uma peça de estrutura bastante repetitiva. Seus elementos da expressão são fortemente - exaustivamente? - recorrentes, criando um ambiente de familiaridade sobre o qual será possível criar tantas surpresas no plano do conteúdo.

Assim, um filme sem atores na acepção corrente (personagens, figuras humanas, etc.) ou músicas conhecidas, e no espaço curto de um minuto, consegue extrair um sentimento de naturalidade daqueles objetos fantasiosos. Não é possível saber se o enunciatário será efetivamente levado a fazer mais compras no site, mas o filme faz com que ele saia da experiência mais "forte" do que entrou. 


\section{Capítulo 4}

\section{A Enunciação de um Valor: Análise de um Filme Publicitário da Cerveja Guinness}

Time present and time past Are both present in time future And time future contained in time past. If all time is eternally present All time is unredeemable. What might have been is an abstraction Remaining a perpetual possibility Only in a world of speculation. What might have been and what has been Point to one end, which is always present. 


\subsection{Enunciação e Metalinguagem}

A partir das considerações de Emile Benveniste, Manar Hammad levanta a hipótese de que a enunciação enunciada é metalinguística em relação ao enunciado enunciado (Hammad, 1983:38). Essa formulação se mostrará bastante proveitosa para a análise da publicidade — aliás, como sugerido pelo próprio autor (Hammad, 1983 :41). Uma das consequências da hipótese é a de que, assim entendido, o enunciado se torna um objeto de valor em circulação entre enunciador e enunciatário, determinando a estrutura de comunicação imanente. Ao apontar essa relação entre enunciação e enunciado, o autor argumenta que não se pode mais considerar os elementos da enunciação como fenômenos tão-somente do nível discursivo, mas que a enunciação ultrapassa esse nível e contém em si todos os elementos de um enunciado: desde suas relações de nível profundo, passando pelos desenvolvimentos narrativos até o nível discursivo.

O filme proposto para esta análise traz elementos que fortemente corroboram a hipótese de Hammad. Mais que isso: enunciado e enunciação estão de tal forma imbricados, que aquele se revelará como figura desta, confirmando a relação metalinguística anunciada pelo semioticista. Nesta análise, procuramos mostrar por que meios essas relações entre enunciado e enunciação se constroem, desde o nível profundo ao discursivo, explicando de que maneira a instância enunciadora perpassa toda a construção do texto. ${ }^{1}$

\subsection{Um Valor a Ser Construído}

$\mathrm{O}$ anúncio publicitário ${ }^{2}$ dura um minuto. Ele apresenta três atores começando a beber cerveja Guinness no balcão de um bar. Estão dispostos em linha de maneira que no centro está o homem negro e mais alto e nas pontas os brancos mais baixos. Ao tomarem o primeiro gole, demonstram aprovação com olhares e gestos de cabeça. No momento posterior, acelera-se o vídeo, que passa a se desenrolar em retrocesso. Os três atores começam a andar para trás e a involuir, seguindo a teoria darwiniana

\footnotetext{
${ }^{1}$ Luiz Tatit comenta em seu trabalho Musicando a Semiótica (Tatit, 1997:15 e ss.) a presença da enunciação em todos os estágios da produção do texto.

${ }^{2}\langle$ www.guinness.com/row_en/ads/Evolution+Original/Evolution + Original + View + Ad $\rangle$ — vide CD anexo: arquivo "c_guinness.wmv"
} 
às avessas. Em volta o espaço começa também a mudar, figurativizando a Terra caminhando na direção do próprio princípio. Ao lado daqueles personagens, vemos o planeta passar por grandes transformações, como o período glacial, grandes movimentações de terra e a queda de um cometa. As transformações figurativas dos personagens são grandiosas na mesma medida. Eles passam de homens a macacos, mas também a animais voadores, formas semelhantes a golfinhos, peixes, dinossauros, seres rastejantes e acabam por se transformar em seres pré-históricos, que são uma espécie de peixe pulmonado. ${ }^{3}$ Cessa a regressão no tempo quando esses peixes pulmonados vão beber, como os homens do início do vídeo. Nesse caso, os atores, agora peixes, bebem água de um pequeno lago. A sanção dessa vez é negativa, demonstrada pelo gesto realizado pelo ator mais à direita, que põe a língua para fora e produz um som de desaprovação (algo como: "puá!"). Esse é o fim do filme, que dá lugar a um epílogo. Surgem, então, na tela três copos de Guinness, sendo que o do centro, mais à frente, tem a espuma bem separada do líquido, de maneira a revelar a típica cor escura e traz o nome e logo da cerveja. Nos outros dois copos a cerveja se mistura à espuma, apresentando uma cor de caramelo, mais clara. Logo acima, os dizeres de um provérbio intitulam o conjunto: good things come to those who wait. O provérbio inglês equivale ao português: "quem espera sempre alcança" e ao pé-da-letra: "boas coisas vêm àqueles que esperam".

Ao final do anúncio publicitário, o espectador é levado a perceber um valor associado à cerveja: o prazer gustativo experimentado pelos personagens. Dessa forma, o filme está criando um objeto de valor - ou ainda atribuindo um valor ao objeto em questão. Conforme será demonstrado na análise, esse valor vai sendo construído no desenrolar da anúncio, de forma a instaurar a cerveja Guinness como um objeto de valor a ser buscado pelo enunciatário.

Ainda que, como vêm demonstrando os estudos da enunciação, estratégias persuasivas estejam em jogo em qualquer texto, no filme publicitário essas estratégias estão colocadas em franco relevo. Na peça em estudo não é diferente. As relações narrativas que constroem e colocam em destaque o objeto de valor serão transpostas, por meio de estratégias discursivas, para a relação entre enunciador e enunciatário. No decorrer da análise que segue, será possível levantar elementos que demonstram essa transposição do

\footnotetext{
${ }^{3}$ Cf. o próprio site da cerveja Guinness citado na nota anterior e 〈en.wikipedia.org/wiki/Mudskipper > para detalhes e foto.
} 
percurso do sujeito do enunciado para o fazer do enunciatário, revelando, assim, a construção da persuasão pelo sujeito da enunciação.

\subsection{Um Outro Valor - a Captação do Texto-base}

Comecemos por observar como se dá essa construção do valor do objeto. $\mathrm{O}$ filme publicitário se constrói a partir de uma paródia da teoria da evolução, de Charles Darwin. Segundo Discini (2004: 27), a paródia “constrói outro sentido, mas para a mesma história do texto-base". Ao criar essa releitura da teoria da evolução, o sujeito da enunciação fez referências expressas ao texto original, que constituem aqui a intencionalidade marcada nas semelhanças e diferenças entre texto-base e paródia. ${ }^{4}$

Ao captar o discurso darwiniano, o enunciador do filme subverte o original apresentando uma involução, na ordem inversa daquela proposta pelo cientista inglês. Mas a ligação ao texto-base vai além das marcas discursivas. A paródia opera também na construção dos valores de base.

Um dos valores centrais que determinam o percurso do sujeito na teoria darwiniana é o da seleção, ${ }^{5}$ ou seja, o indivíduo que tiver as características mais adequadas para a adaptação ao meio prosperará em detrimento dos competidores e, assim, garantirá a mudança, a renovação e a manutenção da espécie. Nessa peça, esse valor também está colocado, ao lado do já mencionado valor do prazer gustativo. Mas, por se tratar de uma paródia, o valor vem torcido. Aquilo que era uma seleção de seres vivos ao longo de sucessivas mutações é trazido para o universo da cerveja. Ao invés de termos um critério de sobrevivência determinando a seleção, teremos uma escolha humana, baseada no prazer, modalizada pelo / querer/ — afinal, apesar de contarmos com diversos seres no decorrer dos tempos, são todos "humanizados", conforme veremos mais a seguir.

\subsection{Construindo um Objeto}

Podemos dividir o texto em três momentos: dois momentos de sanção (no início e no fim) e um momento que liga os dois que é o tempo das

\footnotetext{
${ }^{4}$ Cf. Discini (2004:27). As marcas no enunciado que identificam diretamente o textobase são a "heterogeneidade mostrada" nos termos de Authier-Revuz (1982).

${ }^{5}$ Expresso no famoso bordão "the survival of the fittest" (Darwin, 1872)
} 
transformações figurativas do sujeito. Isso sem contar, naturalmente, a sanção final, que generaliza - com a ajuda do provérbio e, dessa forma, aponta para a imagem do saber incontestável do enunciador implícito.

$\mathrm{O}$ valor em jogo - o prazer gustativo - está dado nos momentos de sanção. A relação está posta, aliás, de forma aparentemente simples. O primeiro momento, em que os homens estão no bar, mostra uma sanção positiva à cerveja. No discurso enunciado, a figura dos olhares e gestos de cabeça concretizam a aprovação à bebida.

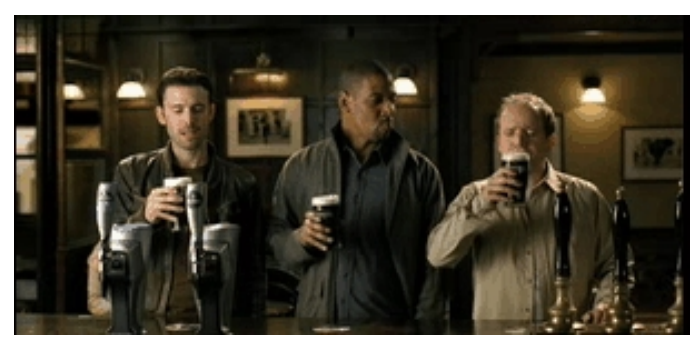

(a) Direção do olhar

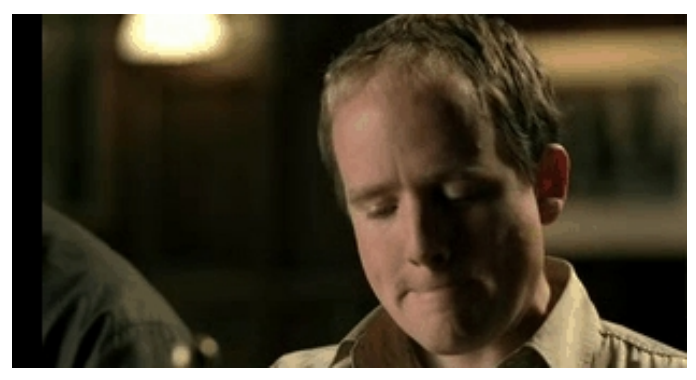

(b) Inclinação da cabeça e movimento dos lábios

Figura 4.1: Primeira sanção

No terceiro momento, os peixes pré-históricos experimentam a água do lago e atribuem a ela, ao colocar a língua para fora da boca com um som de reprovação, uma sanção negativa. 


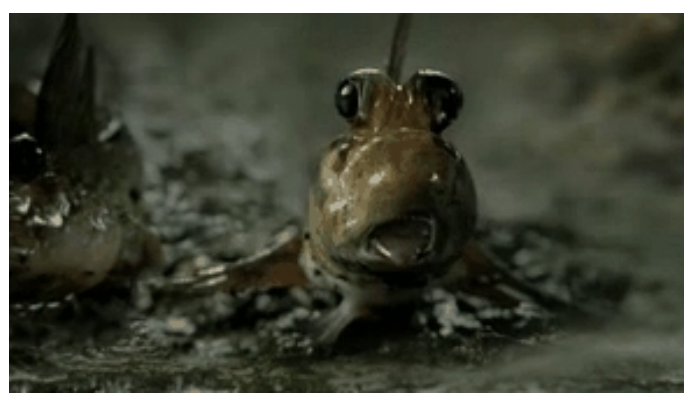

Figura 4.2: Segunda sanção

Uma vez então que o valor está apresentado, o que justifica a parte intermediária que compõe, aliás, a maior parte do filme? Primeiramente, essa fase faz a ligação entre as duas partes de sanção. As transformações graduais dos três atores vão permitir ao enunciatário entender que os três atores da primeira parte (três homens) e os três atores da terceira parte (três seres pré-históricos) são o mesmo sujeito narrativo que exerce o mesmo papel temático por toda a narrativa - sujeitos em busca do prazer gustativo. Essas transformações serão percebidas cognitivamente por meio do apelo a estereótipos nos cenários e nas figuras dos atores. As modificações vão de início de forma gradual - no crescimento da barba, na deterioração e diminuição das roupas, nas árvores que vão decrescendo, etc. Mas, logo que estabelecem uma expectativa no enunciatário, ou seja, criam uma direção, passam a se dar aos saltos — num momento são macacos, no outro, pássaros, em seguida porcos, peixes... A criação desses saltos intensifica a sensação de aceleração das mudanças e do vídeo como um todo. Também intensifica a expectativa do fim.

Essa relação que o enunciatário é capaz de estabelecer entre os atores do filme também produzirá, indiretamente, uma outra relação central para a construção narrativa e discursiva do texto: a ligação que fará entender que a cerveja é a água do laguinho transformada. Desde o começo dos tempos (era pré-histórica), os seres que serão um dia homens buscam o prazer gustativo. A sanção que o peixe realiza no vídeo nos mostra que não se trata de uma busca por sobrevivência, que naturalmente poderíamos associar à ingestão de água, mas de uma apreciação daquilo que se ingere. Depois desse momento, haverá um lapso de bilhões de anos até que esses seres, agora transformados em homens, possam novamente beber. Mas nesse momento, que no vídeo aparece como primeiro, visto que está apresentado 
em retrocesso, os atores bebem Guinness e apreciam aquilo que bebem. As transformações nos atores e no espaço remetem a uma modificação também no objeto. Num primeiro momento (narrativo) tudo o que se tem a beber é água, no momento final aquilo que se dá a beber é a cerveja. Isso, coroado pelos dizeres "quem espera sempre alcança", nos mostra que foi preciso esperar a transformação da bebida de água em Guinness para que ela adquirisse o valor buscado - a transformação é que lhe trouxe o valor em jogo. Se as transformações nos atores, tempo e espaço são de ordem figurativa, a transformação do objeto, diferentemente, se dá em seu valor narrativo.

Falamos de uma transformação do sujeito e uma transformação do objeto. Dissemos que as transformações do sujeito são transformações figurativas. De fato, não está colocado no texto um fazer do sujeito. Não é necessária uma aquisição modal. Ele já conhece seu objeto de desejo e todas as modalidades necessárias à conjunção já estão pressupostas (visto que de fato atinge a conjunção). Uma única modalidade se coloca em questão, ainda que não constitua um problema, uma vez que também desta é dotado o sujeito. Para que se dê a conjunção visada desde sempre, é preciso que o sujeito "saiba esperar". Essa formulação, como explica Greimas (1983:232), não recobre a modalidade do /saber-fazer/, mas a do /poder-ser/. Novamente, isso reforça a ideia de que não há fazer em jogo, apenas ser. ${ }^{6}$

Se articularmos o caminho para a conjunção num quadrado semiótico, de forma a estabelecer graus de proximidade e afastamento entre o sujeito e seu objeto, diríamos que o sujeito, no momento mais distante da conjunção (quando experimenta a água), por estar já dotado de todas as modalidades necessárias, não chega a estar em disjunção, mas em não-disjunção, ou seja, a um passo da conjunção. Isso porque não só o objeto já é visado pelo sujeito (Zilberberg, 2007b:22), mas todas as condições subjetivas para a conjunção já estão presentes.

\footnotetext{
${ }^{6} \mathrm{~A}$ análise do epílogo mostrará também que mesmo a conjunção do sujeito com o objeto, figurativizado no ato de beber, dirá mais respeito ao ser do sujeito que ao fazer (cf. seção "A Volta à Ordem").
} 


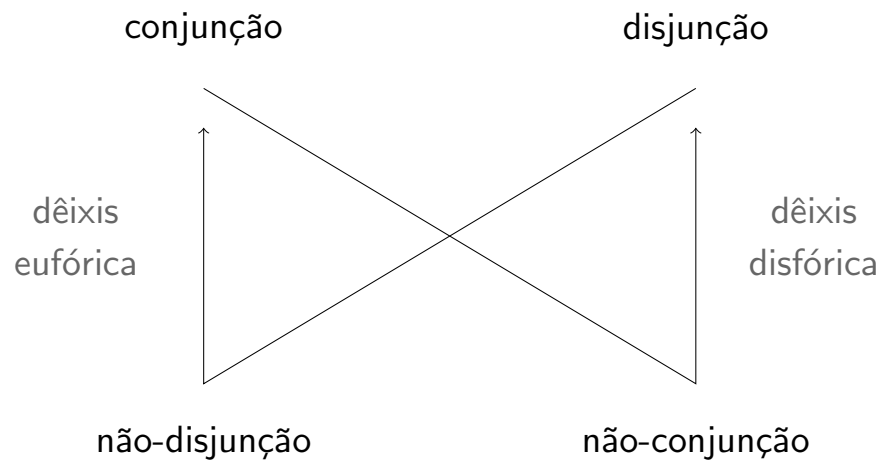

Uma vez que a conjunção é euforizada nesse texto, a constatação de que não há propriamente disjunção e que ele é todo cercado de conjunções ${ }^{7}$ cria - ao lado de diversos outros elementos como a música e o efeito cômico da paródia - faz predominar valores de passagem, desimpedimento e continuidade. Mais à frente, outros elementos da análise virão confirmar essa leitura.

Todo o percurso do sujeito na narrativa é um percurso do ser. Em seu andar, o sujeito é testemunha das mudanças que se operam a sua volta, mas as suas qualidades narrativas já estão dadas desde o início.

De outra natureza é a transformação do objeto. Ela revela um fazer pressuposto - o fazer da cerveja, aquele que transformou a água para que se fizesse a cerveja. A necessidade da longuíssima espera deixa perceber que a aquisição da competência para a modificação da bebida só pode se dar no tempo. Note-se que nada ligado à transformação do objeto nos é dado a ver no anúncio. Ela não conta esse percurso. Daí dizermos que todo o percurso narrativo ligado à transformação da bebida está pressuposto e subentendido. Ao contrário, vemos três sujeitos alheios a essa mudança, que tudo o que fazem para usufruir do objeto é andar, andar toda a história da vida na Terra. $\mathrm{O}$ apagamento da transformação do objeto reforça a cifra tensiva do texto, segundo a qual os valores de desimpedimento mantêm a hegemonia. Ao não revelar o percurso de transformação do objeto, cria-se uma naturalização da mudança e reforça-se a ideia de que, para chegar à cerveja, basta esperar.

\footnotetext{
${ }^{7}$ Conforme veremos mais adiante (seção "A Volta à Ordem”), o anúncio se inicia com uma conjunção, mas também termina com uma, pois o epílogo final trará novamente uma configuração conjuntiva.
} 
Juntamente ao entendimento, na dimensão cognitiva, a seção intermediária traz também consequências para a adesão tímica do enunciatário, o que se revela central para as estratégias manipulatórias do enunciador. Ambas as sanções revelam o valor em jogo, mas é a narrativização, a mobilização das estratégias tensivas e, em especial, a criação de contrastes que garantirá o impacto tímico do valor, ${ }^{8}$ e portanto a adesão do enunciatário ao contrato proposto pelo sujeito da enunciação. Verificaremos agora por que meios são criados esses mecanismos de contrastes e de que forma se constrói a cifra tensiva do texto.

\subsection{O Caminho do Sujeito}

Se olharmos para o andamento desse caminhar, notamos que são movimentos muito mais rápidos do que aqueles dos momentos de sanção. É de fato um relógio acelerado. Vemos toda a história da vida na Terra, como dizíamos, contada nuns 35 segundos. Essa aceleração, que ocorre no segundo momento, tem a função de apresentar exatamente toda a extensão do tempo, mas por outro lado também tem o efeito de colocar essa passagem em relativo segundo plano em relação aos momentos mais lentos. Esse efeito se dá porque, ao se acelerar o discurso, borram-se os contornos (nos dizeres de Norma Discini) e ao enunciatário são dados menos detalhes. Predominam, nesse segundo trecho, câmeras mais distantes dos sujeitos: planos globais e de conjunto. Além de permitirem uma menor apreensão de detalhes, essas câmeras também têm a característica de apresentar de forma global o que está se desenrolando - um enfoque do que poderíamos chamar um plano cognitivo. Temos assim um valor francamente extenso na vasta dimensão de espaço e tempo percorrido, mas de pouca intensidade passional.

Em contraposição, o primeiro e o terceiro momentos se estendem mais lentamente no tempo que lhes é dado. Temos pouca passagem de tempo e poucas ações acontecendo naqueles trechos do texto. O enunciatário tem tempo de ver detalhes, possibilidade corroborada pela câmera em close up ou plano americano. A câmera tímica (em oposição à cognitiva) associada ao andamento lento traz profundidade passional (tonicidade) numa pequena extensão de tempo e espaço (do enunciado). Note-se que

\footnotetext{
${ }^{8}$ Trata-se aqui do reconhecimento do valor do valor (Zilberberg, 1986b:246).
} 
essa dinâmica fica clara se contrastarmos o tempo de manifestação com o tempo narrado. ${ }^{9}$ Na segunda parte observa-se um amplo descompasso entre o tempo do desenrolar do filme (manifestação) e o tempo da narrativa (a história da evolução): este é muitíssimo mais extenso que aquele. Esse descompasso é transposto por dois mecanismos: cortes e saltos no tempo, de um lado, e aceleração dos movimentos no vídeo, de outro. Percebemos, contudo, uma concomitância entre o tempo da manifestação e o tempo narrado na primeira e na terceira parte. Não só temos uma câmera em aceleração normal, mas também os gestos dos atores são gestos lentos (o que é diferente de uma câmera lenta).

A predominância de valores intensos nos pontos extremos (início e fim) em oposição aos valores extensos do percurso intermediário cria um efeito de saliência. Temos os extremos marcados em relação ao intervalo não-marcado. São os momentos de sanção que nos trazem o valor do objeto. Mas, ao criar essa oposição, o texto atribui mais relevo aos momentos de parada, enriquecendo ainda mais o valor criado. Claude Zilberberg, em "Condições Semióticas da Mestiçagem", levanta a hipótese de que:

o quantum de afeto "disponível" seria constante e divisível, de tal maneira que, se a operação de triagem se tornou impraticável, o quantum de afeto atribuído a uma única grandeza é máximo ou, por outras palavras, sublime. Em contrapartida, se se proceder a uma operação de mistura e depois, por recursividade, a uma série de operações de mistura, haverá ao mesmo tempo uma difusão extensiva e uma diluição intensiva, com o que cada grandeza implicada no processo receberá uma quantidade menor (Zilberberg, 2004:74-75)

Essa perspectiva vem ao encontro da estrutura do filme e esclarece o mecanismo de criação de contraste. Segundo essa hipótese, o longo trecho central dilui o afeto na sua grande extensão de tempo e larga amplidão do espaço. $\mathrm{O}$ mesmo afeto está concentrado e tonificado no curto desenrolar do tempo e no espaço restrito (o interior de um bar e a beira d'água) das passagens de abertura e fechamento da narrativa.

\footnotetext{
${ }^{9}$ Entendemos por tempo de manifestação ou tempo de textualização a duração "real", isto é, cada um dos segundos que perfazem o minuto de duração do filme. Por outro lado, o tempo do narrado ou tempo do discurso são os milhões de anos de transformação da terra que são recontados nesse anúncio. Devemos os termos tempo de textualização e tempo do discurso a Diana Luz Pessoa de Barros.
} 
De volta à questão da enunciação, o percurso do sujeito do enunciado, quando se completa encerrando o texto, se configura como um instrumento de manipulação - como aliás qualquer texto, uma vez que todo texto constrói uma manipulação entre enunciador e enunciatário. Ainda assim, esse aspecto manipulatório está ressaltado no texto publicitário, posto que, mais que convencer da verdade - entendida como uma concomitância do ser e do parecer (Greimas \& Courtés, 1993:419) —, o texto publicitário aponta para um fazer no mundo - o valor construído no texto quer levar o enunciatário a comprar a cerveja.

\subsection{O Componente Musical e a Divisão do Texto}

As partes que compõem esse anúncio são marcadas também pelo componente musical. A trilha sonora do filme propõe um casamento do registro erudito e popular que vai ordenar as sequências narrativas. A primeira parte - a abertura - conta com instrumentos sinfônicos. Ao iniciar a segunda parte, esses instrumentos serão substituídos pelos do rock, ganhando um arranjo popular. O terceiro momento, em que os peixes bebem da água do lago, verá o retorno dos instrumentos sinfônicos que se encontrarão então misturados aos instrumentos do rock, mas também será acrescentado um coral de orquestra. Essa mistura permanece no epílogo onde, apesar da predominância dos instrumentos de orquestra, ouvimos ainda a voz do vocalista de rock.

É possível notar uma divisão de funções ligadas a um e outro registros. $\mathrm{O}$ registro erudito dos instrumentos sinfônicos está sempre ligado aos momentos de sanção. Se buscarmos no intertexto os valores associados a esses instrumentos, traremos pelo menos a ideia que já está contida no próprio termo "erudito": um valor solene que se vê emprestado a esses momentos de sanção. Por outro lado, o valor "popular" do rock parece confirmar a análise de que o trecho intermediário se deixa correr na extensidade - é o trecho não-marcado. Entretanto, é com a associação do erudito ao popular que se dá o desfecho do anúncio, apontando, dessa forma, para uma composição de valores no texto. 


\subsection{A Sanção Estética}

Foi levantado acima um paralelo entre as transformações do homem e a que se opera na bebida. Tem-se assim que o sujeito evoluiu do peixe pré-histórico ao homem moderno e a água evoluiu para se tornar a cerveja. Nesses termos, foi possível traçar uma relação entre enunciação e enunciado. No decorrer de sua involução, o homem passa por diversos estágios de inacabamento. Seu estado final é um ser grotesco, parte peixe, parte sapo, mas ainda com traços humanos nos seus gestos faciais e na voz, ou seja, nas habilidades comunicativas. É por meio delas que se apreende o traço humano, mais essencial dos peixes. Esse traço revela o mesmo sistema de valores do homem ocidental moderno - que é também o do enunciatário do filme publicitário.

Assim, cabe ao enunciatário proceder a uma sanção estética: contrastase o acabamento do homem à figura inacabada do ser original. Essa sanção operada no nível discursivo é paralela à sanção do nível narrativo: ambas são sanções estéticas, uma da ordem visual e a outra da ordem gustativa, e ambas avaliam positivamente a fase moderna (homem e cerveja) e negativamente a fase pré-histórica (peixe e água). Está aí a primeira relação entre o percurso do sujeito do enunciado e o fazer do enunciatário.

Mais consequências se podem tirar dessa aproximação entre o homem e a cerveja. O epílogo, última parte do filme, já depois de "encerrada" a narrativa, traz novos elementos para essa associação. Conforme vimos na descrição do filme na introdução desta análise, o anúncio conta com três personagens dispostos como mostrou a figura 4.1 acima. Apontamos também a diferença de altura e cor da pele. Quando surge a tomada final, veem-se três copos de cerveja dispostos em posição bastante semelhante à posição em que se mantiveram os personagens por todo o filme. Além do número coincidente de elementos (três) e da disposição em que estão colocados, a diferença de altura entre os homens também encontra paralelo na apresentação dos copos. Como o copo do centro está ligeiramente mais à frente que os outros dois, ele parece maior e mais alto que os demais, assim como o ator que ocupa o centro do trio. 


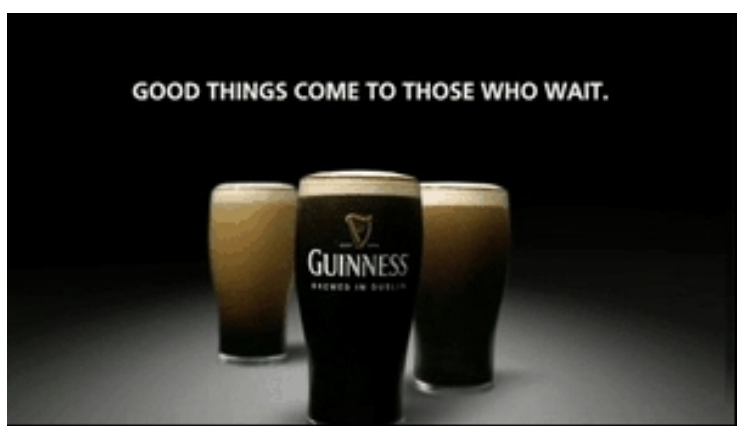

Figura 4.3: Trio de copos

Ademais, a cor também exerce um papel importante. Guinness é originalmente uma cerveja do tipo chopp, servida do barril direto no copo. Também é uma cerveja preta, mas de espuma quase branca. Quando servida, a espuma se mistura à cerveja dando-lhe um tom caramelo. ${ }^{10} \mathrm{Na}$ tomada final, o copo do meio tem a cerveja já separada da espuma e é, portanto, um líquido preto; os outros dois copos têm a espuma ainda misturada à bebida, fazendo uma cor clara. Na composição do trio de personagens, tínhamos exatamente essa disposição: o homem negro e alto no centro, ladeado de seus companheiros de cor branca. Esses diversos traços figurativos - cor, número, disposição, altura - contribuem para uma leitura dos três personagens como figuras da cerveja. Assim, de volta ao processo de transformação dos personagens, se entendemos que os homens e a cerveja são um só, podemos perceber que a evolução por que passou o ser pré-histórico para chegar a sua forma humana "acabada" também é aquela pela qual passou a água para se tornar cerveja.

\subsection{A Volta à Ordem}

Um outro elemento visual traz à baila a questão da enunciação. A apresentação da cerveja no epílogo não se dá de forma estática. Os copos vêm na direção do espectador. Seja como um brinde ou uma oferta, a aproximação dos copos se revela como uma marca da enunciação no enunciado;

\footnotetext{
${ }^{10}$ Essa característica - da cerveja preta com a espuma branca - constitui-se como uma das identidades da marca. Tanto esse contraste quanto sua mistura caramelo foram muito explorados em diversos comerciais da marca, inclusive nas cores de fundo do cenário, como são as cores do bar na cena que abre este filme. Cf. 〈www.guinness.com/row_en/ads $\rangle$.
} 
ela constitui um diálogo gestual. Esse movimento apresenta uma direção "desinvertida". O filme foi quase todo feito não só num retrocesso temporal, mas com figuras que efetivamente andam para trás, numa ordem "antinatural". Assim, o epílogo traz uma volta à "normalidade", bem como um retorno ao início - novamente temos a boa bebida, não é preciso beber a água desagradável.

O retorno ao início devolve ao enunciatário a perspectiva da conjunção. Até o fim do percurso dos personagens eles estão se afastando da conjunção do início do comercial - visto que estamos em retrocesso. No epílogo, o retorno da cerveja e o movimento dos copos na direção do enunciatário retomam a cena inicial e traz a iminência da conjunção. Mas desta vez, como estão instaurados no enunciado ${ }^{11}$ o enunciador e o enunciatário, é este último que está na beira da conjunção. A tentação não poderia estar mais clara. Uma vez bem construído o valor do objeto, se o enunciatário está convencido dos valores em jogo, a oferta desses valores revela um / poder/ do enunciador-manipulador, que conhece o objeto de desejo a ser buscado pelo enunciatário, e, ao mesmo tempo, um / querer/ do enunciatário que está pronto a aderir ao contrato, cujos termos foram traçados no decorrer do texto. ${ }^{12}$

Mais ainda. A partir dos traços de semelhança que apontamos entre os homens e os copos de cerveja, poderíamos dizer que há um sincretismo (Hjelmslev, 2003:93-94) ${ }^{13}$ dessas duas figuras. Há sincretismo quando dois elementos, que em outros contextos seriam considerados distintos em relação ao sistema linguístico em que se inserem, num dado contexto têm suas diferenças suspensas e são tratados como exercendo a mesma função. Sujeito e objeto são invariantes, ou seja, ocupam lugares distintos no esquema narrativo. Mais precisamente, o sujeito, na teoria semiótica, é um ser cindido; ${ }^{14}$ é aquele a quem falta uma parte e que, portanto, está

\footnotetext{
${ }^{11} \mathrm{~A}$ respeito da enunciação enunciada e os tipos de marcas que a enunciação inscreve no enunciado, cf. Fiorin (2002 :36-38 e 43-44) e Hammad (1983). Fiorin argumenta que não se pode determinar, num inventário fechado, quais seriam essas marcas. Sua observação é especialmente pertinente para que se alargue o mecanismo discursivo da debreagem para outras linguagens, como nesse caso a visual.

${ }^{12}$ Para um maior desenvolvimento das modalidades envolvidas nos processos de persuasão, cf. Barros (2001 :38-39)

${ }^{13}$ Para uma revisão das formulações desenvolvidas nesse texto de Hjelmslev e algumas consequências desses conceitos na teoria semiótica, cf. Fiorin (2009).

${ }^{14}$ Essa ideia foi primeiro sugerida na teoria semiótica em Greimas \& Fontanille $(1991: 21$ e ss.) e posteriormente desenvolvida por outros semioticistas (cf. Tatit 1997:14-15; Zilber-
} 
sempre em busca do que lhe falta - do objeto.

Sujeito e objeto definem-se um pelo outro: sujeito é aquele que busca o objeto e objeto é aquilo que é buscado pelo sujeito (Greimas \& Courtés, 1993 : 259 e 270). A busca pela conjunção com o objeto de valor é o que dá sentido - significado e direção (Zilberberg, 1986b:245) — ao percurso do sujeito. Assim, ao dizermos que há um sincretismo de actantes, isso não vai sem consequência. A conjunção sugerida no texto é extrapolada. Ao criar o simulacro da possibilidade de transpor o fazer do sujeito do enunciado (beber cerveja) para o fazer do enunciatário (por meio da oferta dos copos de cerveja no epílogo), o enunciador havia instaurado um / poder-ter/ o objeto de desejo. Assim, se no início do texto tivemos uma conjunção interrompida, nos termos da semiótica tensiva, tivemos uma parada. Esse retorno ao início e à conjunção perdida configura-se, para a instância da enunciação, em uma parada da parada, ou seja, ainda que a narrativa tenha sido apresentada de forma invertida e tenha sido encerrada pelo seu início e, portanto, distante linearmente da conjunção, para o enunciatário, permanece a impressão de uma ordem canônica: da conjunção inicial instaura-se a falta que será sanada com a conjunção final.

Por outro lado, ao trazer aquela série de traços em comum entre os homens e a cerveja e sugerir ao enunciatário que leia um e outro como o mesmo, o enunciador está caminhando na direção de uma fusão entre sujeito e objeto. A fusão é o estágio zero da triagem e máximo da mistura (Zilberberg, 2004:75-78), em que sujeito e objeto encontrariam de novo a unidade (Greimas, 1987:31). Diferentemente da conjunção inicial, em que o sujeito / pode ter/ o objeto, encontramos aqui a possibilidade da conjunção plena - um / poder ser / completo. O texto vai, assim, além da retomada da conjunção. É o limite da extensidade e dos valores de passagem - do desimpedimento — é a continuação da continuação (Tatit, 1997 :15-18). No limite, a continuação da continuação leva à extinção, pois, uma vez que fundido ao seu objeto de desejo, não resta ao sujeito mais nada a buscar e, portanto, não há mais sentido - nas duas acepções sugeridas acima. É por isso que, ao chegar nesse ponto, ou bem se acaba a narrativa ("e viveram felizes para sempre") ou instaura-se uma nova parada que permitirá que se inicie uma nova narrativa: "tout commence par une interruption" (P.

berg 2006b:140-145). Greimas \& Courtés (1993: 259) fazem referência a essa cisão quando mencionam o processo de debreagem como uma projeção (do objeto de conhecimento no caso do sujeito da enunciação) para fora do sujeito. 
Valéry, apud Tatit 1997:15). Nesse caso, é precisamente nesse tom eufórico de total conjunção que se encerra o anúncio publicitário. A continuidade entre sujeito e objeto se configura, assim, como o máximo da absorção do valor pelo enunciatário. 


\section{Capítulo 5}

\section{Do Icônico ao Simbólico: Estratégias para a Construção do Sentido}

Pois aquilo é ferro forjado.

Flores criadas numa outra língua.

Nada têm das flores de fôrma moldadas pelas das campinas.

[...]

Forjar: domar o ferro à força, não até uma flor já sabida, mas ao que pode até ser flor se flor parece a quem o diga.

João Cabral de Melo Neto 


\subsection{Da Natureza à Cultura}

$\mathrm{Na}$ análise que apresentaremos a seguir, examinamos o modo pelo qual referências icônicas podem ser usadas para provocar um efeito de estranhamento, que apenas encontrará solução quando esses mesmos elementos convergirem para o registro simbólico. Para tanto, como corpus dessa investigação escolhemos a campanha publicitára da Budweiser, lançada em 1994. ${ }^{1}$ Embora vamos nos ater ao primeiro anúncio que deu origem à série, faremos por vezes menção a outros filmes que fizeram parte de toda a campanha.

Esse primeiro filme se inicia com o enquadramento de um sapo num lago, que coaxa repetidas vezes. A ambientação no lago, com os sons de grilos e pererecas, criam a cena. Os sons de fundo geram o elemento contínuo que será pontuado pelo coaxar do sapo. Cria-se assim um paradigma, uma isotopia da natureza que é a chave para a leitura icônica. Aos poucos, o coaxar de três sapos vai se destacando e uma série de elementos parecem ficar fora de lugar para que seja possível fazer uma leitura plenamente icônica de toda a cena. Ao fim da publicidade, o enunciatário percebe que o ruído dos sapos deve, diferentemente, ser lido no registro da cultura: são sapos humanizados, que falam as sílabas da marca de cerveja Budweiser, lidas por eles do letreiro luminoso de um bar à sua frente.

Esse percurso de leitura do texto, que perfaz a passagem do registro da natureza para o registro da cultura será espelhado em variadas dimensões. Assim, da mesma forma que é convidado a seguir a via de leitura que parte da natureza em direção à cultura, o enunciatário também é levado a realizar outros percursos de leitura que vão, (i) da substância dos sons desconexos dos sapos à forma manifestada no nome de uma marca reconhecível e contextualizada, (ii) do não saber (aqui entendido como uma suspensão do entendimento gerado pelo efeito insólito desses sapos que não se encaixam bem no "contexto natural" criado pelos elementos de ambientação) ao saber (quando da resolução do filme) e, como já sugerimos, (iii) do icônico ao simbólico.

Levando em consideração as questões mencionadas até aqui, exploraremos a seguir o papel desempenhado pelo andamento na passagem do

\footnotetext{
${ }^{1} \mathrm{O}$ filme original pode ser visto em: $\langle$ www.youtube.com/watch? $\mathrm{v}=i 4 \mathrm{Uje} 7 \mathrm{IwVY} 4\rangle$. Uma compilação dos filmes publicitários ligados a essa sequência pode ser encontrada em $\langle$ www.youtube.com/watch?v=f3mXaATLeRM $\rangle$.
} 
icônico ao simbólico, a construção do efeito insólito e a composição dos elementos de expressão e conteúdo nessa construção.

\subsection{Andamento e Saber}

Parece bastante plausível pensar que é necessária uma certa moderação no andamento da apresentação de conteúdos num texto. Ao elaborar um texto, podemos supor que uma apresentação do conteúdo excessivamente rápida pode gerar confusão no enunciatário. Não nos referimos aqui a uma aceleração da expressão, embora essa também possa causar problemas. Imagine-se a possibilidade de assistir a um filme, do começo ao fim, rodado duas vezes mais rápido do que o habitual. Certamente ocorrerão confusões aí também. Mas, como dizíamos, estamos no registro do conteúdo e de como esses conteúdos são apresentados ao enunciatário. Se houver um fluxo muito grande de informações novas sendo apresentadas em sequência, o enunciatário pode se sentir saturado e não mais ser capaz de acompanhar o sentido do texto. Saltos e elipses, em que não é possível estabelecer a ligação entre causa e consequência, por exemplo, criam, no texto, um efeito de sentido de aceleração, e, por isso, exigem do enunciatário maior esforço para recuperar a coesão entre as partes do texto. A assimilação de novos conteúdos depende de contextos familiares, da existência de um equilíbrio entre novo e conhecido. No caso de uma aceleração excessiva, será necessário ao enunciatário retraçar seu caminho para recuperar o fio perdido.

E como seria no caso de um texto demasiadamente desacelerado? Se pensássemos, por exemplo, num texto em que cada novo elemento fosse introduzido muito lentamente, distante de outras novas informações que poderiam se acrescentar, acompanhado de um excesso de detalhes e conteúdos já conhecidos, sem nenhum espaço para inferências, dificilmente teríamos um enunciatário disposto a acompanhá-lo em seu andamento - em oposição àquele outro que simplesmente não pôde fazê-lo devido à aceleração extrema. Nos dois casos, o texto se perde como objeto para o enunciatário. $\mathrm{Na}$ aceleração, é o texto que escapa ao enunciatário. $\mathrm{Na}$ lentidão, o desligamento está associado à perda de interesse.

Naturalmente, esses limites podem ser testados e invertidos. Se empurrarmos a fronteira da lentidão ainda para mais longe e imaginarmos uma 
introdução de conteúdos ainda mais escandida no tempo, é possível que cheguemos ao limite da memória, e que o enunciatário passe a novamente não poder acompanhar o texto por não ser capaz de ligar as partes num único enunciado coerente.

\subsection{Na Publicidade}

Nesse contexto de acelerações e desacelerações, entramos no domínio da publicidade. Não estamos mais, porém, no mesmo registro de excesso, uma vez que a publicidade prima, via de regra, pelo que podemos chamar de bom timing - o ajuste do tempo para causar o maior impacto possível. É assim que o clássico anúncio dos sapos da marca de cerveja americana Budweiser explora as modulações de andamento para criar os efeitos de sentido vistos no texto.

O filme publicitário da Budweiser vai trabalhar no extremo da desaceleração, mas, ao invés de gerar o tédio e o desinteresse que levam o enunciatário a não querer acompanhar o texto, vai provocar justamente aquilo que se espera do texto acelerado: o não poder entender — nesse caso, o non-sense.

Como vimos acima, o anúncio traz um elemento de continuidade nos sons de fundo que será marcado pelo coaxar dos sapos. O barulho produzido pelo primeiro sapo é, entretanto, sui generis. Lembrando que o filme foi criado para o mercado norte-americano ${ }^{2}$, o sapo não reproduz nem exatamente um verdadeiro coaxar, nem a onomatopeia inglesa ribbit, mas produz, num som grave, a sílaba bud. Em inglês, essa sílaba compõe por si só uma palavra que pode ser traduzida por "amigo" ou "companheiro". A associação desses elementos naturais do contexto ao falar destoante do sapo constrói um certo estranhamento. Isso é particularmente acentuado pelo gênero de que o texto faz parte. Fosse um programa televisivo de canais como o Animal Planet ou o National Geographic, que tratam da vida animal, a sílaba diferente talvez passasse despercebida. No contexto publicitário, sua estranheza sobressai.

\footnotetext{
${ }^{2}$ Esse filme foi apresentado ao público nos intervalos da $28^{\mathrm{a}}$ versão do Superbowl em 1994. O Superbowl é a final do campeonato de futebol americano nos Estados Unidos e traz, tradicionalmente, algumas das campanhas publicitárias mais caras do ano no país (La Monica, 2007).
} 
Com o desenrolar do filme, a câmera passará a focalizar outros dois sapos que produzem duas novas sílabas. À direita do primeiro sapo ("Bud"), o menor dos sapos fala a sílaba weis. Em inglês, mais uma vez, a sílaba por si só constitui uma palavra que, com o mesmo som mas outra grafia — wise -, constrói a palavra "sábio". "Bud" e "Weis" alternam algumas vezes até que intervém o terceiro sapo com a sílaba er. Trata-se, dessa vez, de uma interjeição dicionarizada que demonstra hesitação. No uso popular, também pode ser usada para descrever uma situação estúpida ou uma pessoa de pouca inteligência. ${ }^{3}$

Ao final do anúncio, o enunciatário é capaz de montar as sílabas para formar o nome da cerveja: bud-weis-er. Entretanto, de início, as sílabas são apresentadas fora de ordem e muito lentamente. A sequência de apresentação das sílabas até que se forme pela primeira vez o nome da marca é a seguinte:

bud-bud-weis-bud-bud-weis-bud-er-bud-weis-bud-er-weis-bud-bud-weis-er

Uma vez que as sílabas encontram a ordem que forma o nome da marca, altera-se sua velocidade de produção. Se antes tínhamos uma sílaba a cada um ou dois segundos, agora temos todo o conjunto produzido em aproximadamente um segundo, e sendo repetido também a cada segundo.

A apresentação de conteúdos, como fizemos supor acima, é de tal forma lenta e desordenada que o enunciatário não é capaz de compor a palavra que esclarece o suspense construído no texto. Durante a maior parte do filme, o enunciatário permanece num estado de suspensão do entendimento que gera um efeito do que poderíamos chamar de insólito - um estado em que o enunciatário é capaz de compreender cada um dos elementos presentes, mas parece não haver uma razão, um sentido, para que os elementos estejam dispostos e relacionados daquela maneira.

A criação desse efeito de "insólito" se dá, como dissemos, pela associação entre a ambientação natural e os sapos que falam sílabas um tanto misteriosas. No entanto, esse efeito é potencializado pela dimensão temporal, ou seja, a insistência e a extensão no tempo desse jogo aparentemente sem sentido provocam um acréscimo gradual de tensão. Ao mesmo tempo, a reiteração do enquadramento nos sapos e do vai-e-vem das sílabas deixa claro que, no desfecho da narrativa, a solução do anúncio virá também

\footnotetext{
${ }^{3}$ Os sapos da Budweiser vieram a ser conhecidos exatamente pelas sílabas que produziam: Bud, Weis e Er. Cf. Raugust (1998).
} 
pelo coaxar. De fato, uma vez que as sílabas começam a ser faladas na sequência que forma a marca, o jogral dos sapos se altera: a palavra é repetida mais vezes e de forma mais acelerada, antes que a câmera mude de direção, mostrando as costas dos sapos e o letreiro luminoso onde leem insistentemente "bud-weis-er".

Ao final do anúncio, quando o coaxar dos sapos adquire uma nova dimensão, percebemos que as sílabas do início formavam um verdadeiro paradigma que trazia, virtualizada, a marca da cerveja. A marca é então atualizada por meio da sintagmatização das sílabas, ou seja, quando as sílabas ganham uma ordem constante e uma periodicidade, fazendo com que formem um conjunto. Podemos dizer, nesse sentido, que, no momento em que subitamente se revela a marca Budweiser, ocorre a ultrapassagem de um limite, resultado da formação repentina de uma totalidade que ainda não se podia adivinhar na declinação progressiva das suas sílabaspartes. Por outro lado, quando surge o letreiro, a marca ganha densidade de presença. A focalização do luminoso corresponde, de um lado, à realização do nome que se formou no cantar dos sapos, de outro lado, à compreensão da "origem" da fala dos sapos, que liam de um letreiro. A marca realizada no letreiro traz a perspectiva de uma conjunção plena dos personagens e do enunciatário com o objeto.

A consciência das sílabas se dá por meio de uma reconstituição empreendida pelo enunciatário numa retroleitura que se segue à compreensão global da peça. É nesse momento que surge a interpretação de que os sapos estavam todo o tempo lendo o luminoso. Dessa forma, há uma inversão de direção entre enunciação e enunciado. Neste, o nome da marca vai se construindo de suas partes (as sílabas) até formar uma totalidade, em outros termos, do paradigma ao sintagma. Na enunciação, é apenas depois de termos a solução linguística dos ruídos emitidos pelos sapos, ou seja, a composição do nome da marca, que podemos reconstituir o paradigma inicial, a compreensão de que os ruídos eram, na verdade, sílabas.

\subsection{Contribuições da Figuratividade}

Numa publicidade de narrativa tão econômica, é de se perguntar como se constroem os sujeitos. De início, podemos vê-los como meros sujeitos de um fazer mecanizado, da repetição constante de uma mesma sílaba. 
No entanto, se investigarmos um pouco mais em detalhes os elementos figurativos colocados, notaremos algumas sutis diferenças na configuração temática de cada um dos atores.

Primeiramente, como já levantamos acima, os nomes dos sapos, Bud, Weis e Er, associam-lhes diferentes papéis temáticos: o amigo, o sábio e o tolo. ${ }^{4}$ Em seguida, podemos perceber uma diferença de altura na voz de cada sapo. Bud é mais grave, Weis mais agudo e Er tem altura intermediária. Essa variação em altura parece combinar com as diferenças em tamanho. Bud é o maior, Weis, o menor e Er tem tamanho médio.

Se nos voltarmos mais uma vez para as variações no tempo de execução das sílabas, notaremos que Bud e Er são mais lentos e Weis quebra o ritmo, por vezes, ao se precipitar na hora de entrar com sua fala; chega mesmo a acavalar sua sílaba à sílaba de Er, num dado momento. Ora, se consultarmos a palavra sábio em dicionários de língua inglesa e portuguesa, encontraremos, em ambos os casos, semas desacelerados como parte de sua definição, como prudente e judicioso, por exemplo. Podemos, assim, entender essa precipitação de Weis como irônica e, dessa forma, contribuindo para o efeito geral de comicidade. Er, por outro lado, está perfeitamente inserido em seu papel de tolo, uma vez que é o mais lento do grupo. Não só é o último sapo a começar a participar do jogral, como também é o que fala menos vezes e chega a atrasar sua entrada na terceira vez. Há, assim, uma quebra no ritmo, um desequilíbrio que prepara a resolução. Esse atraso coincide com a primeira aparição do nome da marca na sequência esperada e com o instante anterior ao surgimento do nome compactado num bloco sem intervalo entre as sílabas. A mudança no andamento das sílabas é o começo do fim. A partir de então, todo o mistério em torno da vocalização dos sapos começa a se desvendar, culminando na apresentação do letreiro.

Essa recategorização dos atores do enunciado, como sapos humanizados, também contribui para a criação do efeito "insólito", pois é mais um elemento fora de lugar na cena natural do lago. Por outro lado, diferenças de tempos de entrada de cada um dos sapos podem mostrar que suas falas estão fora de compasso e pedem por um ajustamento que será realizado

\footnotetext{
${ }^{4}$ É curioso notar que essa campanha teve continuação numa sequência de anúncios que exploravam mais os elementos narrativos. Numa delas, Weis é eletrocutado por um lagarto enciumado do sucesso dos sapos. No filme seguinte, é Bud - o amigo - quem vai confrontar o lagarto em defesa de Weis. Os nomes também evocam personagens tradicionais (com seus respectivos papéis actanciais) das narrativas populares: o tolo como herói, o sábio como doador (algumas vezes como destinador) e o amigo como adjuvante.
} 
somente nos instantes finais, próximo à conclusão do texto. Podemos ainda entender essas repetições como um fazer obsessivo de um desejo cristalizado. Esse desejo inferido do fazer cristalizado dos sapos será explorado pela marca numa das muitas continuações propostas para essa campanha publicitária, em que os sapos, depois de muito cantarolar o nome da cerveja, invadem o bar em frente com o letreiro luminoso para roubar a bebida. Essa ligação obsessiva dos sapos com a cerveja constrói uma estratégia concessiva do texto que visa ampliar o impacto e, com isso, o efeito persuasivo da cena: mesmo no mundo natural a marca da cerveja é irresistível ou, de outra perspectiva, a cerveja é capaz de humanizar até mesmo o mundo animal.

\subsection{Interação entre Expressão e Conteúdo}

Voltando ao efeito de insólito de que falávamos acima, verificamos que participam de sua criação tanto elementos da expressão quanto do conteúdo. No início, as imagens nos são apresentadas em close ups e planos de conjunto $^{5}$ e, dessa forma, não é muito além dos sapos e seu entorno imediato que nos é dado ver. Nesse mesmo momento, o enunciatário começa a ser apresentado aos conteúdos insólitos, dos quais emerge a questão: a que vieram esses sapos atípicos, num contexto não exatamente natural.

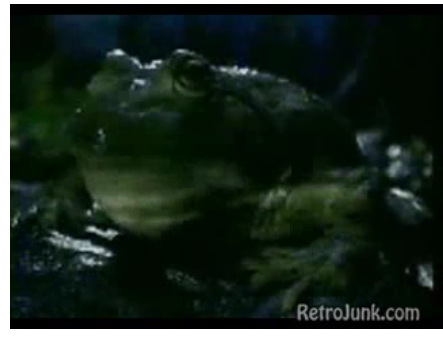

(a) Bud

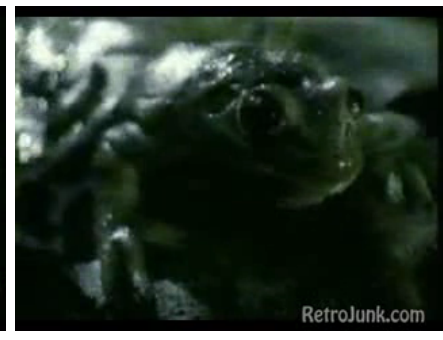

(b) Weis

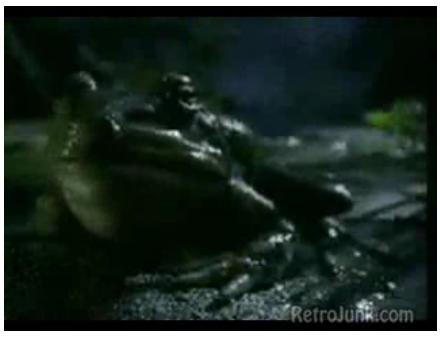

(c) $\operatorname{Er}$

Figura 5.1: Três Sapos

O plano da expressão tem que ser considerado a partir das coerções impostas por esse sistema de significação que é a propaganda publicitária

\footnotetext{
${ }^{5}$ Quando há um personagem no enquadramento, os close ups mostram o rosto e os planos de conjunto apresentam o corpo inteiro. Em nenhum dos casos se vê muito do que está em volta.
} 
televisiva. Em nosso caso particular, é necessário, portanto, que se leve em consideração os jogos de câmera que vão determinar a configuração da espacialidade e que, ao valorizar uma aproximação das figuras dos atores do enunciado na escolha da focalização, vão apresentá-la de início concentrada. ${ }^{6}$ Aos poucos, a focalização se abre e a espacialidade se amplia no plano global para revelar o ambiente em volta, começando pela exposição da lagoa, cujos elementos característicos estavam apenas sugeridos pela sonoridade de fundo e pelo pouco que se podia observar ao redor dos sapos, e, se aproximando do final, pela apresentação do bar, com seu efeito ao mesmo tempo surpreendente e esclarecedor do comportamento atípico dos sapos.

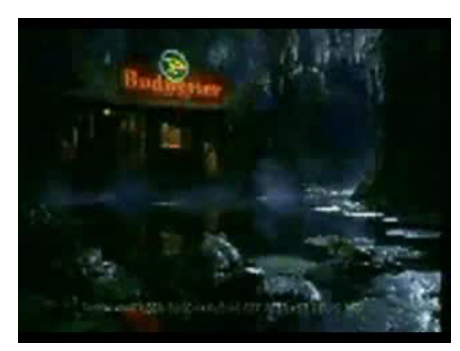

Figura 5.2: Budweiser

Um outro elemento relevante no plano da expressão é o andamento. Se tomarmos o coaxar como ponto de partida, vemos que, de início, os sons são introduzidos lenta e esparsamente. Quando as sílabas se combinam em nível sintagmático para formar a marca Budweiser, a velocidade de apresentação cresce para determinar um andamento mais acelerado, gerando uma direcionalidade no sentido da aceleração (Zilberberg, 2006a:61). Esse movimento de aceleração crescente encontra um correlato numa direção ascendente na tonicidade ligada às vocalizações. Se no início as sílabas são desconexas, instáveis, "frouxas", ao final, quando fazem parte da palavra, elas se reúnem num único bloco coeso, onde se percebe mesmo um pico de acento na segunda sílaba.

Se constatamos uma relevância desses critérios para a organização dos elementos expressivos, podemos, então, associá-los de tal forma a apresen-

\footnotetext{
${ }^{6}$ Como já comentamos nas análises dos anúncios da cerveja Guinness e do Ministério da Justiça francês, a aproximação da câmera tem o papel de exibir pouco da paisagem, apresentando a parte selecionada em muitos detalhes.
} 
tar uma direcionalidade da expressão. Na representação abaixo, escolhemos retratar as subdimensões do andamento e da espacialidade:

Expressão

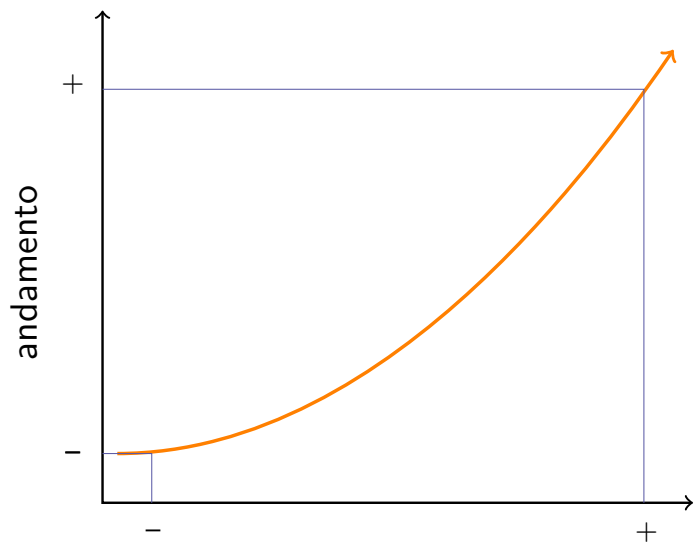

espacialidade

Na análise do plano do conteúdo do filme, observamos uma direção também ascendente do andamento. Em primeiro lugar, porque as figuras do conteúdo parecem apontar para significações diferentes. Ao enunciatário, são apresentados elementos da natureza e coaxares artificiais que não se encaixam no contexto - formam um fazer repetido que não parece ter ordem ou direção. Há, entre esses componentes díspares, um quiasmo. Ao mesmo tempo, vimos que a repetição do jogral dos sapos vai a cada momento recrudescendo o mistério. Assim, quando vão sendo introduzidos os barulhos de fundo e cada um dos sapos e à medida que se desenha esse jogo sem sentido, a tensão vai crescendo. Quando é introduzida a marca da cerveja, é como se houvesse uma passagem abrupta de um regime da desordem para um regime da ordem, em que elementos dissociados subitamente passassem a tomar uma única direção. Essa passagem abrupta, ao mesmo tempo em que acelera o conteúdo, traz impacto à marca apresentada.

Por outro lado, vemos que o sujeito do enunciado - realizado em superfície pela figura dos sapos - é regido por uma temporalidade a cada momento mais paralisada. No início, ainda é possível perceber algum progresso temporal no texto, na medida em que há desigualdades no falar de 
cada sapo. Entretanto, assim que os coaxares se transformam no nome da marca, ela passa a ser repetida, sem modificação, indefinidamente. Apesar de o filme acabar logo depois disso, a recitação vai sumindo paulatinamente com uma redução gradual de volume, sugerindo que os sapos continuariam a cantarolar sem um fim determinado. Como veremos no próximo capítulo, na seção "O Papel da Repetição", a reiteração incessante de um mesmo esquema - seja de elementos singulares, como as sílabas, seja de certos grupos de fatores, como a figuratividade dos sapos - gera uma concentração temporal. Tudo ocorre como se, apesar de o tempo passar, não houvesse uma verdadeira evolução temporal. Trata-se de um tempo rítmico, cíclico, involutivo (Tatit, 2007b:71 e ss.). Acerca da canção, Luiz Tatit (2007b:75) escreve: “a involução descreve os movimentos melódicos que tendem a sincretizar as duas funções [sujeito e objeto]". Em nosso caso, trata-se da mesma relação entre o fazer repetitivo do sujeito que cria essa estagnação no tempo e a busca pela conjunção total com o objeto. Assim, essa temporalidade refreada se ajusta perfeitamente à apreensão de que o fazer desses animais pode ser uma expressão de um desejo obcecado, de um querer que, apesar de não realizado, não oscila e se mantém forte e constante.

Por fim, também percebemos uma tendência do texto para o fechamento espacial. No primeiro momento, ainda que muito discretamente, há alguns movimentos de cabeça, piscares de olhos. Uma vez que a câmera se distancia, tudo se passa como se esses movimentos deixassem de ser significativos. Só vemos três figuras estanques, pregadas a uma posição, vidradas, a olhar o letreiro. Dessa forma, podemos dizer que se trata de um sujeito que não é capaz de apreender o espaço aberto que o envolve, ficando confinado ao seu objeto de valor. É nesse sentido que, apesar de a câmera revelar um entorno amplo, o espaço figural de atuação desse sujeito é restrito, dada a sua perfeita imobilidade. Ademais, a focalização final da câmera também sugere uma concentração da espacialidade, uma vez que três figuras (mais o telespectador, por meio da própria câmera) dirigem seu olhar para um mesmo ponto - o letreiro luminoso - , formando um $\mathrm{V}$, cujo vértice atrai a direção do desejo do sujeito do enunciado e - essa parece ser a estratégia buscada —, se não do desejo, pelo menos da atenção do enunciatário. A formulação acerca da atração que o objeto exerce sobre o sujeito traz à baila a discussão sobre a apassivação do sujeito frente ao objeto estético (Greimas \& Fontanille, 1991:30). Ainda que estejamos aqui 
em outro contexto, a construção de um objeto arrebatador que imobiliza o sujeito se mantém e corrobora a leitura de que estamos diante de um sobrevir, em que, instaurada a marca-objeto, o sujeito passa a um estado de "sofrer" (a influência desse objeto poderoso), e não de agir (Zilberberg, $2007 b$ : 22). Note-se que o fazer dos sapos, ao se mostrar repetitivo e circular, revela não ter direção. Esse fazer sem "sentido" é mais uma constatação de que está representado no filme um sujeito de estado, e não de ação.

O espelhamento das subdimensões da extensidade é previsto na teoria, uma vez que a dimensão é composta de temporalidade e espacialidade e a relação $e . . . e$ determina uma relação conversa (Fontanille \& Zilberberg 2001 : 26; Zilberberg 2006c :171). Dessa forma, é esperado que as variações de temporalidade e espacialidade corram em paralelo. ${ }^{7}$ Da mesma maneira, as subdimensões da intensidade - tonicidade e andamento - são convergentes. Entretanto, o contraste entre subdimensões de eixos diferentes pode resultar em curvas com diferentes configurações e direções. Nesses termos, vemos que a associação do andamento e da espacialidade do conteúdo vai produzir um resultado bastante diferente do esquema da expressão.

\section{Conteúdo}

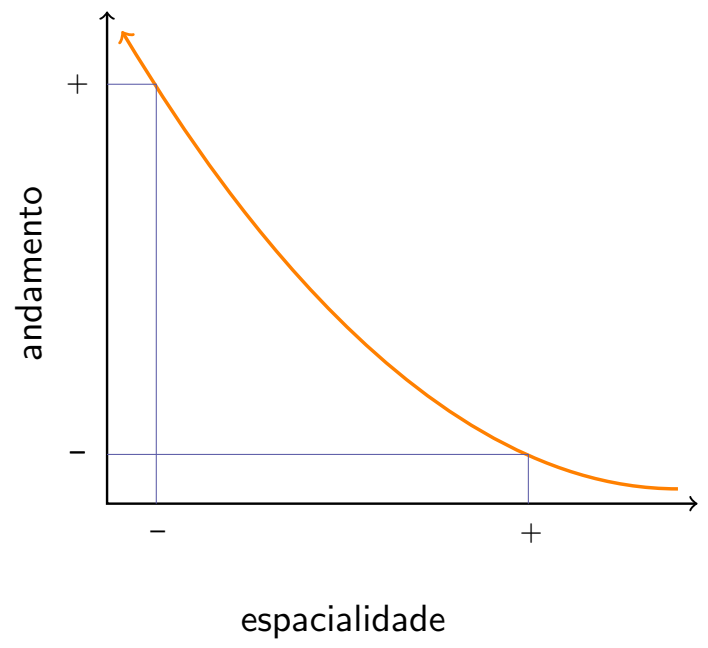

Enfim, podemos observar a interação entre o esquema traçado para a

\footnotetext{
${ }^{7}$ Agradeço a Renata Mancini, que esclareceu essas relações entre subdimensões tensivas em seu curso "Questões Contemporâneas em Semiótica: a Tensividade e o Acontecimento" realizado na USP em maio de 2009.
} 
expressão e o esquema do conteúdo. Apesar de a espacialidade, no plano da expressão, se dirigir para a abertura e, superficialmente, vermos uma ambientação externa, à beira de um lago, a análise do estado do sujeito revela uma tendência à concentração espacial na dimensão figural. Por outro lado, andamento de expressão e conteúdo caminham na mesma direção da aceleração. Apesar da direção convergente, a coincidência entre expressão e conteúdo é, nesse caso, mais intrigante do que esclarecedora, uma vez que vemos uma tendência inversa nos demais textos analisados. O que observamos em geral é uma desaceleração da expressão, quando o conteúdo está acelerado, como se o enunciatário precisasse de mais tempo para dar conta dos novos sentidos que se apresentam de maneira apressada. Essa aceleração da expressão - quando talvez se esperasse uma desaceleração, em analogia com os demais textos - pode ter sua raiz nos comentários que fizemos ao início da análise. Esse anúncio parte do limite mínimo da desaceleração e é somente por meio da aceleração que suas partes ganham sentido. Naquele momento, mais desaceleração corresponderia à extinção.

\subsection{Minimalismo e Impacto}

Há muitas formas de generalizar os objetivos da publicidade. Podemos, grosso modo, imaginar três logo de saída: (i) o objetivo de apresentar um produto ou uma marca; (ii) o de convencer que um produto ou uma marca tem certas vantagens ou traz certos valores e (iii) o de fazer lembrar. $\mathrm{O}$ anúncio minimalista dos sapos da Budweiser parece, em superfície, fortemente centrado neste último objetivo. Passamos o filme inteiro às voltas com o nome da marca. Não se apresentam qualidades do produto ou sequer se vê embalagem, textura, referência ao sabor. No entanto, o que fixa essa publicidade na memória é menos a repetição incansável da marca, mas principalmente o impacto produzido.

O suspense crescente seguido da satisfação da descoberta conquista a cumplicidade entre enunciador e enunciatário. Acompanhamos, no texto, a construção de um efeito de plenitude, por meio de uma ampla conjunção entre sujeito e objeto. No enunciado, os sapos, que vivem nesse mundo híbrido, a um só tempo natural e cultural, mostram, com sua recitação obsessiva do nome da cerveja, um desejo cristalizado e, como sugerimos 
acima, a própria cerveja como um objeto fortíssimo, ${ }^{8}$ capaz de humanizar seres da natureza. No cantarolar dos sapos, está patente a perfeita conjunção do sujeito com o valor do objeto. Essa conjunção plena será espelhada na enunciação, por meio da relação entre enunciador, mensagem publicitária e enunciatário. A construção de um percurso de descoberta, que culmina numa convergência de todos os sentidos dirigidos para a marca apresentada no final do anúncio, vai convidar o enunciatário a retraçar seus passos a fim de desacelerar a narrativa, para, em retrospectiva, montar novamente a história de seu todo até suas partes nas sílabas iniciais. Essa plenitude deve, então, ser potencializada (memorizada) pelo enunciatário da propaganda, para que se transforme em diferença tônica, no sistema mnésico, e motive novas realizações, ou seja, novas experimentações do texto e, talvez idealmente, do próprio produto - mas, aqui, a semiótica já não mais pode interferir. Por fim, é assim que, ao trazer o impacto da descoberta da marca e a possibilidade da realização plena, o anúncio minimalista da Budweiser trabalha por arraigar-se na memória do enunciatário.

\footnotetext{
${ }^{8}$ Essa formulação remete a uma modalização do objeto. Estamos aqui pensando na atratividade que o objeto exerce sobre o sujeito e que instaura, efetivamente, o liame juntivo entre os actantes. Cf. Greimas \& Fontanille (1991:25-26).
} 


\section{Capítulo 6}

\section{Algumas Constantes da Semiótica dos Anúncios Publicitários}


Uma vez apresentadas as análises, podemos agora propor alguns comentários gerais que se aplicam ao conjunto de anúncios selecionados para esta pesquisa. O caráter bastante geral das observações que virão a seguir talvez se prestem a uma extensão ao discurso ${ }^{1}$ publicitário.

\subsection{A Música}

Os componentes musical, verbal e visual vão se compor das mais diversas maneiras e desempenhar diferentes papéis em cada filme publicitário que nos propusemos a analisar. Procuraremos, nesta seção, traçar observações acerca de duas constantes que se associam ao componente musical: a divisão das partes do filme e a contribuição da música para os conteúdos passionais. $^{2}$

A música tem o papel de marcar as partes do texto e as transições entre essas partes. Nesse sentido, tínhamos na publicidade do Ministério da Justiça francês a primeira parte que conta com música pulsante, correspondendo, no plano das imagens, ao close up do rosto do ator do enunciado. Na passagem para a segunda parte, quando muda também o plano de enquadramento da câmera, percebemos a transição no registro musical para um desenvolvimento mais melódico. Essa passagem é marcada por uma nota contínua, que vem da música da primeira parte e se mistura ao desenvolvimento da música da segunda parte. Essa nota, ao mesmo tempo em que faz a passagem entre as partes, revela que, fundido à música inicial, estava o som de um medidor de batimentos cardíacos. É essa nota

\footnotetext{
${ }^{1}$ Supomos que as generalizações que estamos propondo digam respeito, mais precisamente, a um subgrupo dos anúncios publicitários. Notadamente, na questão do clímax, podemos citar um estilo de publicidade em que o locutor imprime a todo tempo uma tonicidade à voz para anunciar ofertas e liquidações. Esse estilo de anúncio parece apresentar vários picos de tonicidade na expressão, tanto na voz quanto na apresentação visual dos elementos na tela. Entretanto, no conteúdo, observam-se poucas variações de tonicidade e poucos elementos de surpresa. Essas características da expressão e do conteúdo já o tornam bastante distinto do estilo dos textos analisados aqui. Cf. $\langle$ www.youtube.com/watch? $v=N$ JyHP-SdLjk $\rangle$ para um exemplo desse tipo de publicidade. Não entraremos em maiores detalhes acerca dos subgêneros da publicidade televisiva, pois foge ao escopo deste estudo.

${ }^{2}$ Essas observações cabem somente aos filmes publicitários que possuem música de fundo, o que, por essa razão, exclui o anúncio da cerveja Budweiser.
} 
alongada, acima de tudo, que age como uma desencadeadora de isotopia e faz entender que aquela música ritmada representava os batimentos do coração da moça, mas só depois de ter parado de bater. A figura de hospital que vemos nas imagens da segunda parte já estava representada pela música na parte inicial, embora seja apenas em retrocesso que se pode perceber esse caráter figurativo da primeira parte da música. A música da segunda parte segue até o fim. Entretanto, ao final do filme, uma nota mais aguda produz uma suspensão - portanto uma tensão - que, por sua vez, vai pedir por uma solução musical. A nota de resolução, mais grave, coincide com a mudança de quadro que apresenta as informações ligadas ao órgão oficial e meios de acesso ao ministério. Há, assim, três partes no anúncio, claramente acentuadas pelas mudanças na música.

Na publicidade do Submarino, analisamos em detalhes a participação da música. Falta-nos apenas acrescentar que a música contém uma pequena abertura, composta apenas pela base do piano. Ela servirá também de base de introdução da frase que se inicia e que garante a coesão dos objetos apresentados no desenrolar da peça: "e se existisse...". A base permanece, mas incluem-se novas notas que vão compor a primeira parte. Uma alteração na música, sem mudança no tipo de disposição gráfica dos elementos, cria apenas uma espécie de cesura, uma variação que interrompe a repetição e deixa perceber um progresso no texto. Na passagem da segunda parte da música para a parte final, há um trecho marcado por tensão melódica e por diminuição do andamento que, como no outro anúncio mencionado, gera uma suspensão ao mesmo tempo que faz a ligação entre as partes por meio da expectativa produzida no enunciatário. A terceira parte é, na verdade, um retorno ao motivo musical da primeira parte. Esse retorno ao conhecido no componente musical coincide com o momento de distensão, que vem associado à resolução no plano do conteúdo e à apresentação da marca.

Por fim, o caso da cerveja Guinness não é diferente, no sentido de que também aí a música marca as partes. Como propusemos no Capítulo 4, o anúncio pode ser dividido em quatro partes: uma sanção inicial, uma parte intermediária, a segunda sanção e o epílogo. Cada uma dessas partes pode ser identificada por uma série de fatores que apontamos na análise: entre eles as variações na trilha sonora. Um arranjo erudito está presente na primeira parte do filme em que se dá a sanção positiva da cerveja. $\mathrm{Na}$ parte intermediária, temos o arranjo de rock. Voltamos ao registro erudito 
na terceira parte com a segunda sanção, mas dessa vez misturado com os elementos do rock. Nessa parte há, assim como no caso do filme do Submarino, a criação da suspensão pela presença de notas tensas. Essa tensão musical se resolve na sequência decrescente, na parte que chamamos de epílogo, onde aparece a marca da cerveja.

A música na publicidade parece ter também - e talvez primordialmente - a função de ordenar certos conteúdos patêmicos. Como podemos conferir na seção "O Papel da Repetição" abaixo, a música usa, por exemplo, de elementos repetidos para criar aumentos de tensão. Nesses mesmos termos, a música pode ser usada para criar um certo andamento das emoções. Tomemos, por exemplo, a publicidade do Ministério da Justiça francês. No início, vemos um rosto em close up, em que paulatinamente vão aparecendo ferimentos, ao mesmo tempo em que expressões de afetividade vão surgindo escritas na tela. A música pulsante e ritmada dessa parte vai pontuar a entrada de cada ferida e de cada uma das expressões verbais. Com sua ação intermitente, ela se contrapõe ao elemento de progresso contínuo gerado pelo acúmulo das lesões e pelo aumento de intensidade do conteúdo verbal. Para que possamos perceber e sentir os conteúdos de um texto, há que se ter um equilíbrio entre o progresso e a permanência, entre o novo e o já assimilado. Um texto cujo conteúdo é todo composto por novidade torna-se de difícil compreensão; por sua vez, outro que só traz informação conhecida não desperta o interesse do enunciatário (Tatit, 1997 : 23-24). O componente musical nessa primeira parte parece garantir um elemento de conhecido, que cria uma oposição à progressão do texto (como veremos, esse não é o único elemento de repetição), que colabora com a adesão do enunciatário. A batida ritmada também contribui para a criação de suspense. Num segundo momento do texto, a música deixa a marcação forte da pulsação ritmada e ganha um desdobramento mais melódico. Essa transformação na música, ao lado das mudanças nas imagens e no texto verbal, acompanha a realização da morte do ator do enunciado. A melodia vai então dar o tom passional que permite ao sujeito se recuperar da surpresa da perda do objeto e entender as razões por detrás dela. A desaceleração do conteúdo é, dessa forma, traduzida pela melodia desacelerada. 
A música do anúncio do Submarino já foi analisada em mais detalhes e já pudemos argumentar sobre os meios pelos quais ela corrobora os valores eufóricos e conjuntivos que predominam no texto. No caso do anúncio da Guinness, estudamos o modo como o registro erudito na trilha sonora está associado aos momentos de sanção na narrativa. Na primeira e na terceira parte, os atores do enunciado experimentam a cerveja e a água, respectivamente, atribuindo-lhes um julgamento estético. Nesses trechos do filme, o registro erudito da música se combina com a desaceleração dos movimentos e a aproximação da imagem para corroborar os valores de suspense e intensidade passional ligados à sanção. Por outro lado, o trecho de música que traz um arranjo popular tem andamento acelerado, como também os movimentos do vídeo, e, nesse ponto, temos um fazer repetitivo e de pouco acento no conteúdo. A música acompanha, com sua rapidez, o pouco desenvolvimento narrativo que perdura por um trecho mais alongado do filme.

A partir dos comentários particulares, podemos contrastar o uso da trilha sonora na publicidade do Ministério de Justiça, de um lado, e nos anúncios do Submarino e da Guinness, de outro. Nestes dois últimos filmes, a música repetitiva (e acelerada, nesse caso) é associada a valores de passagem, fortemente euforizantes. Em ambos os anúncios, quando entram paradas, modificações ou desdobramentos melódicos, eles sempre trazem consigo trechos impactantes ou mudanças no percurso. Por exemplo, no caso do Submarino, percebe-se uma nota tensa (fora do campo harmônico), seguida de uma pausa, que prepara o desfecho final. No filme da Guinness, temos uma introdução e uma coda da música que ganham um tom bem mais solene que o trecho em arranjo de rock da parte intermediária, mais átona. Na publicidade do Ministério de Justiça, diferentemente, é o trecho mais repetitivo da música que está presente no momento mais tônico. $\mathrm{Na}$ realidade, a estratégia que está sendo usada é a de um recrudescimento da tensão pela repetição excessiva. ${ }^{3}$ Por outro lado, quando a música ganha direção melódica, neste filme, a tensão acumulada na primeira parte começa a se resolver numa possibilidade de reelaboração desses conteúdos, por parte do enunciatário, em valores sociais e mais distanciados - em oposição ao impacto da morte de uma única mulher, o texto vai tratar a questão como um problema da coletividade. Por outro lado, se compararmos o

\footnotetext{
${ }^{3}$ Veremos os efeitos dessa repetição mais em pormenores nos itens a seguir. Também a repetição na música dos demais filmes não é isenta de efeitos de tensão.
} 
andamento da música nesses filmes, perceberemos a seguinte oposição: nos filmes em que os conteúdos veiculados são, de maneira geral, eufóricos (Submarino e Guinness), somos apresentados a uma música de andamento mais acelerado; no filme de tom grave e disfórico (Ministério da Justiça), a música é, independentemente de suas partes, mais lenta. ${ }^{4}$

\subsection{A Câmera}

No que tange ao componente visual, trataremos apenas de algumas escolhas ligadas à focalização da câmera nos anúncios em que isso entra em questão. Assim como não havia o que dizer a respeito do elemento musical, no anúncio da cerveja Budweiser, por não haver trilha sonora, também no caso do Submarino, não há o que comentar em relação ao uso de câmera. Durante todo o filme, permanece sempre a mesma focalização, sem aproximação, distanciamento, mudança de ângulo, não criando, dessa forma, contrastes significativos internos ao texto. Portanto, mencionaremos apenas os filmes do Ministério da Justiça, da Guinness e da Budweiser.

Nos três anúncios que se servem de variações no enquadramento da câmera, fizemos notar que, consistentemente, as focalizações mais aproximadas dos atores eram usadas em momentos de mais intensidade passional. Por outro lado, um maior distanciamento da câmera, com apreensão de mais elementos do cenário, está ligado aos momentos de esclarecimento, com "explicações" de questões deixadas em suspenso, enfim, tem relação com os conteúdos cognitivos em geral. No anúncio da Guinness, em particular, observamos mudança na expressão facial dos três homens quando experimentam a cerveja e também na careta que faz o peixe pulmonado na segunda sanção. Já no trecho intermediário, menos tônico, predominam tomadas mais distantes, que revelam o contexto ao redor dos atores. Nos outros dois filmes, não há mudança na gestualidade facial dos atores: no anúncio do Ministério da Justiça francês, por exemplo, a moça mantém a mesma expressão por todo o filme (o que entendemos como expressão da sua passividade); no anúncio da Budweiser, por se tratar de sapos, por um lado, mas também por estes realizarem um fazer repetitivo, não há

\footnotetext{
${ }^{4}$ Essa relação entre valores conjuntivos expressos por composições mais aceleradas e valores disjuntivos ligados a composições de andamento mais desacelerado já foi largamente explorada no universo da canção popular por Luiz Tatit (Cf., por exemplo, Tatit 1997, 2007b).
} 
exatamente uma mudança de estados patêmicos. É curioso comparar a gestualidade facial dos sapos (Budweiser) com a expressão do peixe pulmonado (Guinness). A gestualidade deste revela uma mudança de estado no momento em que experimenta algo que lhe provoca repulsa - a água do lago. No caso dos sapos, como dissemos, não há essa mudança, uma vez que seu desejo e seu estado de conjunção nunca se alteram - eles não chegam a provar a bebida. ${ }^{5}$ Ainda que não haja alteração na gestualidade facial dos sapos, a câmera apresenta um enquadramento aproximado dos atores e chega a revelar apenas um de cada vez, quando não apenas seu rosto. Também nesse caso, nas partes de apreensão, há um afastamento da câmera, que passa a tomar também o entorno.

Em “Conditions d'une sémiotique du monde naturel", Greimas (1970: 4991) propõe uma tipologia da gestualidade humana. Entre os tipos levantados pelo autor, interessa-nos a gestualidade atributiva, que transmite as "atitudes e estados interiores fundamentais" (Greimas, 1970:71). Esses conteúdos atributivos podem ser percebidos pela disposição de diversas partes do corpo isoladamente (como, por exemplo, a inclinação do tronco) ou por uma composição delas. Grande parte da informação, porém, é comunicada pela disposição facial. Assim, se estamos tratando de textos fílmicos, serão relevantes a parte do corpo do ator que é focalizada e a distância do enquadramento. Nesse sentido, podemos sugerir que a frequente associação desses conteúdos atributivos à gestualidade facial pode estar na raiz dessa escolha pela focalização aproximada dos atores do enunciado nos momentos em que conteúdos atributivos estão sendo construídos. Assim, a aproximação do rosto do ator pode diretamente apresentar o estado de alma que o texto procura elaborar, como é o caso do anúncio da Guinness. Observamos que a câmera tem aí a função de dirigir a atenção do enunciatário. Na parte em que a câmera está afastada dos atores, há a ação do tempo, os sujeitos são passivos e apenas aguardam as mudanças prometidas. A aproximação da câmera aponta para a ação sancionadora do sujeito - realizado figurativamente seja nos três homens, seja nos peixes pulmonados. Essa aproximação traz a possibilidade do discurso direto que não vem pela via verbal, mas pela gestualidade dos

\footnotetext{
${ }^{5}$ Cabe aqui também uma observação quanto à diferença de técnica na comparação entre os anúncios das duas cervejas. No caso da Budweiser, trata-se de um anúncio da década de 1990, em que a computação gráfica ainda não contava com os mesmos recursos que se tem mais recentemente. A publicidade da Guinness, muito posterior, já manipula mais facilmente os elementos gráficos, entre eles a face dos animais.
} 
atores no primeiro momento e na gestualidade associada à interjeição do peixe, no segundo.

A câmera tem, como dizíamos, a função de direcionar a atenção, ao passo que a gestualidade é responsável por apresentar o conteúdo passional. Essa formulação, entretanto, não se aplica a todos os casos, uma vez que nos anúncios da Budweiser e do Ministério da Justiça não há alterações na expressão facial dos atores. Neles, a câmera aproxima a imagem dos atores, sem que haja alteração em suas faces, embora ainda assim seja possível apreender um conteúdo atributivo. Cremos, então, que é justamente a focalização da câmera que assume o papel atributivo. Está codificado na cultura, bem como nos demais elementos internos ao texto - como a música, o elemento verbal, os elementos repetitivos que analisamos até aqui - que uma aproximação da figura traz um incremento passional. Inversamente, o distanciamento da figura aparece associado a conteúdos atributivos mais distensos. Antes mesmo da transmissão de conteúdos patêmicos pelo sujeito do enunciado, há uma escolha de focalização. Não fosse isso, não haveria que se falar em "expressão facial". As estratégias de aproximação e distanciamento da câmera apontam para uma escolha mais global acerca da apresentação dos conteúdos passionais do que meramente a figura localizada no rosto do ator.

Essa associação dos conteúdos atributivos com a aproximação ou distanciamento da câmera não apenas é codificada culturalmente, mas pode também ser descrita por modulações tensivas. A aproximação de um objeto faz com que apenas esse objeto seja visto como presente na tela. Há, nesse sentido, um fechamento da espacialidade, e um único objeto torna-se totalizante, toma todo o campo de presença. Esse fechamento está ligado a um aumento da tonicidade no texto - como no caso dos conteúdos passionais que acabamos de investigar (Zilberberg, 2007a:11-12). Em suma, o que se observa nos textos analisados é uma relação inversa entre as subvalências da tonicidade e da espacialidade. ${ }^{6}$

\footnotetext{
${ }^{6}$ Um exemplo de relação conversa, em que a tomada distante traz mais tensão, pode ser visto no filme Safe, de Todd Haynes, em que as tomadas de longe do ator, Carol White, vêm marcar sua solidão e incapacidade de ação.
} 


\subsection{O Papel da Repetição}

Um dos processos sempre atuantes nos anúncios publicitários escolhidos é a repetição. Essa pode parecer uma observação um tanto óbvia, mas o que interessa aqui é o papel que a repetição desempenha na construção da cifra tensiva de cada enunciado e, em especial, de que forma a repetição é um mecanismo de recrudescimento das tensões no texto.

Nos textos analisados nos capítulos anteriores, os traços repetitivos relevantes para a discussão que estamos propondo são de natureza variada. Serão importantes desde, por exemplo, a reapresentação de uma mesma palavra, sintagma ou célula rítmica, traços figurativos, até mecanismos sintáxicos - no sentido de combinatórios - que se repetem. Qualquer que seja a manifestação do elemento repetitivo, buscaremos, em todos os casos, as ocorrências em que a reiteração esteja relacionada a um aumento de tensão. Com a contribuição da repetição e da tensão, o texto caminhará para o clímax, conforme desenvolveremos na seção seguinte. Veremos aqui quais são as condições semióticas para que as repetições se realizem em modulações tensivas, ou seja, qual o lugar da repetição no arranjo do texto.

Cada vez que nos deparamos com um elemento que repete um anterior, não podemos dizer que encontramos exatamente a mesma coisa, já que eles ocupam lugares diferentes na cadeia. $\mathrm{O}$ contraste com o conceito de isotopia, conforme desenvolvido na semiótica, pode contribuir para essa discussão. O primeiro tomo do dicionário de semiótica (Greimas \& Courtés, 1993 : 197) apresenta como conceito inicial de isotopia:

[... ] a iteratividade, ao longo da cadeia sintagmática, de classemas que garantem ao discurso-enunciado sua homogeneidade. Segundo essa acepção, fica claro que o sintagma que reúne ao menos duas figuras sêmicas pode ser considerado como o contexto mínimo que permite estabelecer uma isotopia. (tradução nossa $)^{7}$

Apesar de ser um conceito que coloca em evidência as semelhanças entre os termos (semas, figuras, etc.) no discurso, a isotopia também traz consigo

\footnotetext{
7“le concept d'isotopie a désigné d'abord l'itérativité, le long d'une chaîne syntagmatique, de classèmes qui assurent au discours-énoncé son homegénéité. D’après cette acception, il est clair que le syntagme réunissant au moins deux figures sémiques peut être considéré comme le contexte minimal permettant d'établir une isotopie."
} 
a possibilidade da diferença. O conceito de isotopia trata da reiteração de traços entre os elementos do processo. Assim, a semelhança entre os termos numa cadeia fará com que alguns traços semânticos de cada termo sejam reforçados, enquanto outros traços que não são comuns aos termos da cadeia sejam apagados. Os elementos que formam o entorno de um dado termo entram na composição do sentido geral do texto, mas também na interpretação que se deve dar ao primeiro termo daquela cadeia. Em outras palavras, a isotopia tem efeito extenso, contribuindo para o sentido global do texto, mas também, por meio da seleção de traços semânticos, determina a interpretação que se obtém de cada um dos termos que a compõem. Por outro lado, se dois termos semelhantes, ou mesmo idênticos, aparecem lado a lado na cadeia sintagmática, somente podemos notar o que há de comum entre eles porque também percebemos que não são exatamente o mesmo. O primeiro corresponderá ao novo, à apresentação de uma informação. O segundo, simplesmente por ocupar essa posição, será já conhecido. É ele, e não o primeiro, que determina que há uma isotopia, ou melhor, é a relação que se estabelece entre os termos. Dessa maneira, é necessário o estabelecimento de uma função $e \ldots e^{8}$, para que se possa configurar uma isotopia. Assim, ao mesmo tempo em que reitera o sentido do primeiro, o segundo fecha as possibilidades de leitura, restringe as tantas linhas de sentido potencialmente abertas pela introdução de um termo ainda não atado por um contexto subsequente.

A repetição se aproxima da ideia de isotopia, na medida em que também apresenta recorrências de significados. Em outras palavras, se, na isotopia, um mesmo sentido está sendo disseminado ao longo do texto, por meio da reiteração de semas, também podemos perceber, na repetição, uma disseminação de sentidos. Entretanto, na repetição, não são semas selecionados de itens distintos, mas o mesmo item de superfície ${ }^{9}$ sendo repetido diversas vezes: como, por exemplo, a repetição de uma sequência de notas na música do filme do Submarino (ver a figura 3.7 no Capítulo 3) ou a repetição de uma sílaba no coaxar dos sapos da Budweiser. Essa semelhança apontará para um mesmo estilo tensivo, que é também o mesmo que

\footnotetext{
${ }^{8} \mathrm{~A}$ função $e . . . e$ diz respeito aos elementos dispostos em cadeia e, portanto, coexistentes na dimensão sintagmática (Hjelmslev, 2003:41-43).

${ }^{9}$ Insistimos na ideia de que é na superfície que há a repetição, porque, como expusemos acima, há uma diferença entre os termos em função do lugar em que eles aparecem na cadeia.
} 
observamos nas explicações e definições em relação ao termo de partida.

Se o primeiro elemento de uma repetição é percebido como a entrada do novo e o segundo como uma reiteração, uma expansão do mesmo sentido pelo texto, poderíamos talvez aproximar a repetição à explicação. Quando desenvolvemos a explicação de um termo, transformamos um sentido condensado em uma série de outros termos que elaboram e estendem no tempo e no espaço os sentidos veiculados pelo primeiro. ${ }^{10}$ Da mesma forma, a repetição estaria reapresentando e dilatando no tempo e no espaço um mesmo sentido. Entendida dessa maneira, a repetição apresentaria um estilo descendente (Zilberberg, 2006a:16-25), uma vez que se inicia na tensão da surpresa, do novo, e se dirige para o conforto do habitual.

Entretanto, ao mesmo tempo em que um elemento está se repetindo, ele não está sendo desenvolvido exatamente nos mesmos termos de uma explicação. Se pensarmos na construção de um dicionário, a mera repetição produziria um dicionário ineficiente, uma vez que a definição de um termo que contivesse o próprio termo não traria esclarecimentos acerca de seu significado. Também nesse sentido, a repetição apresenta uma singularidade que a difere do conceito de isotopia. Afinal, se apenas um mesmo elemento reaparece a todo momento, que traços semânticos selecionar? Perde-se algo central na noção de isotopia: a direção. Por um lado, a semelhança entre os termos os reúne numa mesma isotopia, mas, por outro, a sua diferença garante que haja um caminho de leitura, e não deixa o texto em aberto para qualquer leitura. A perspectiva da explicação está ligada a um desenvolvimento dos traços que, paradoxalmente, restringe a gama de leituras. ${ }^{11}$ A expansão associada à explicação é oposta ao efeito produzido pela repetição constante. Se algumas ocorrências de um mesmo elemento trazem o conforto do conhecido, a insistência gera uma exaustão.

Se entendida dessa forma, a estrutura da repetição comporta uma flutuação de estilos tensivos. No início, ao opor novo e conhecido, os elementos repetidos de um texto vão apresentar um estilo descendente. Tudo ocorre como se houvesse uma regra a ser apreendida. Primeiramente, os ele-

\footnotetext{
${ }^{10}$ A definição dos dicionários se assemelha à explicação nos termos que foram colocados aqui e apresenta o mesmo estilo tensivo descendente para Zilberberg (2006a:47).

${ }^{11}$ Num comentário jocoso, um amigo dizia que, na filosofia, é bastante mais confortável dizer que dois termos muito próximos não são o mesmo conceito do que dizer que são. $\mathrm{Na}$ raiz dessa observação, está a ideia da restrição provocada pela isotopia. A dessemelhança exclui uma leitura, mas, ao apontar uma igualdade, você se compromete com um sentido, excluindo todos os demais.
} 
mentos são apresentados como desconexos. Tão logo o enunciatário se dá conta da expectativa de repetição, o novo, mais tenso, passa a figurar numa sequência e entra para o conforto do esperado. Acontece que mesmo o estilo descendente encontra o seu limite mínimo. A insistência da regra pode começar a produzir o efeito inverso. O caráter complexo e opositivo da linguagem faz com que a excessiva afirmação de um termo gere a presença de seu oposto pela falta (Tatit, 2007a:31). Assim, o que era uma afirmação do conhecido passa a clamar por uma mudança. É dessa maneira que a repetição, seja de um mesmo elemento, seja de uma regra combinatória, começa a produzir um acréscimo de tensão na expectativa de uma mudança.

Nesse sentido, a repetição pode ser comparada ao mecanismo de abertura e fechamento silábicos proposto por Saussure. Em seu capítulo acerca dos princípios da fonologia, Saussure (1997: 64-72) propõe quatro combinações possíveis dos fonemas da língua. Duas delas fazem supor um caminho numa mesma direção. O elo explosivo $[<<]$ descreve um caminho na direção do aumento de sonoridade, como na combinação de uma consoante oclusiva seguida de uma fricativa. No elo implosivo [ $>>$ ], está descrita a diminuição de sonoridade, como no caso de uma vogal ser seguida por uma consoante em posição de coda. Entretanto, as outras duas combinações são mais diretamente relevantes, uma vez que apresentam limites e mudanças de direção. O grupo explosivo-implosivo $[<>]$ representa o limite máximo de sonoridade e, portanto, o núcleo silábico. Atingido o limite máximo de sonoridade, resta a queda. Ao núcleo silábico sempre deve seguir um elemento de menor sonoridade. Não fosse assim, seria o segundo elemento, e não o primeiro, o núcleo. No entanto, é o grupo implosivo-explosivo $[><$ ] que se assemelha ao esquema da repetição. Dizíamos que, uma vez estabelecida a regra, sua excessiva repetição atingirá um limite de atonia. Nesse momento, a repetição passa a ser "desconfortável". Também na sílaba, o grupo implosivo-explosivo representa esse limite mínimo que pede por uma virada, ou seja, marca o início de uma nova sílaba. Da mesma maneira, a repetição vai caminhando na direção do fechamento, até que novamente seja necessária uma resolução. Trataremos, a seguir, desse aspecto de tensionamento da repetição. De toda maneira, esse esquema de aberturas e fechamentos cria um sistema de previsões 
e expectativas, ou seja, cria uma ritmização da expressão linguística. A repetição parece ser uma das formas de gerar um fechamento no conteúdo. Se correlacionada à proposta saussuriana, contamos com um elemento para descrever mudanças no conteúdo.

A repetição de um mesmo elemento ou mecanismo produz uma cristalização no tempo e no espaço. A cristalização no tempo pode ser descrita em função de uma interação entre as diferentes dimensões temporais identificadas por Claude Zilberberg (1990). ${ }^{12}$ A interação de três delas nos interessa em particular. Como dizíamos, a repetição cria uma direção, uma expectativa de continuidade. Se percebemos que uma sequência está se repetindo, podemos esperar que ela continue na mesma direção. A ideia de que há uma regra para esse progresso estabelece um ritmo (ou temporalidade rítmica, para Zilberberg). A memória - temporalidade mnésica - sobredetermina o ritmo, disseminando-o pelo discurso. Essa difusão da regra gera uma contenção do sentido, uma concentração, que, apesar de disseminada pelo texto, parece sempre apontar para a sua origem, num eterno retorno ao núcleo. Assim, apesar do correr do texto, como somos expostos a conteúdos idênticos ou semelhantes, não temos a sensação de um progresso temporal, estamos sempre nos deparando com aquilo a que fomos apresentados no início. Esse excesso de igualdade desacelera o discurso até que não haja mais metas ou direção.

Esse constante retorno produz uma concentração no conteúdo que é semelhante ao fechamento silábico da expressão linguística proposto por Saussure. Em outras palavras, ao mesmo tempo em que esse fechamento anula a direcionalidade por meio da negação da progressão, a insistência nesse mecanismo vai encontrar o seu limite e pedir por uma mudança. Ao aproximar-se do seu limite, a concentração temporal caminha na direção de uma retomada da direcionalidade através de uma mudança de estratégia, ou seja, da entrada de novos conteúdos.

A concatenação de informações novas traz à baila a terceira temporalidade: cronológica. Ao acrescentar sempre o novo, a temporalidade cronológica traz a perspectiva da irreversibilidade, ou seja, conteúdos conhecidos são deixados para trás e dão lugar ao diferente. Se a determinação da temporalidade mnésica sobre o tempo rítmico expande igualdades, ela também carrega consigo as diferenças. Na sobreposição da temporalidade

\footnotetext{
${ }^{12}$ Os comentários que traçamos aqui partem da revisão empreendida por Tatit (1997: 20 e ss.) em Musicando a Semiótica.
} 
mnésica sobre a cronológica, as desigualdades - ainda que contidas pela insistência na regra - ganharão corpo e exigirão uma mudança. Dessa forma, a repetição controla o progresso textual, pela instauração do tempo rítmico, mas também carrega consigo a necessidade da transformação.

Um outro paralelo interessante pode ser feito com a canção popular, justamente porque a questão da ritmização está tão salientada. Ao tratar da canção de andamento acelerado, Luiz Tatit (2007b: 73-93) acusa uma necessidade de reparar um conteúdo disperso (na ruptura do elo sujeito-objeto), necessidade essa que vai se manifestar numa tendência à concentração. Assim, predominam nesse tipo de canção tematizações e refrãos ${ }^{13}$ que são estratégias para refrear as desigualdades no texto, "investindo na coincidência de acentos e na tendência reiterativa dos motivos" (Tatit, 2007b:77). Essas estratégias da canção acelerada podem ser entendidas como uma força de involução. Tudo ocorre como se a regra viesse negar a aceleração, restabelecendo o elo entre sujeito e objeto.

Assim como vimos argumentando para a repetição em geral, também na canção é necessário reconhecer uma contraparte à involução "para contrabalançar a força de continuidade e desaceleração da involução [...] reforçando a ruptura e a velocidade" (Tatit, 1997:24). Essa contraparte da involução vem na forma de desdobramentos e segundas partes ${ }^{14}$ e pode ser considerada a força de evolução. Em outras palavras, a aceleração da canção popular é "reparada" pelo elemento involutivo que recupera uma unidade ferida pela aceleração - ou talvez a aceleração não seja a causa, mas uma manifestação de uma cisão primitiva (Greimas \& Fontanille, 1991:25-26). A evolução, por outro lado, é o retorno do percurso.

Voltando aos textos publicitários, o componente que estamos reconhecendo como restaurador de unidade são os elementos repetitivos - como também na canção popular, a unidade é garantida por estratégias "fundadas na recorrência". O componente portador de ruptura e que muda a direção do texto é o clímax: o ponto culminante da tensão nos textos publicitários analisados. O clímax é reconhecido, assim, como a entrada

\footnotetext{
${ }^{13}$ A tematização forma "núcleos localizados, fundados na recorrência". O refrão é a "manifestação extensa desta força de involução [...], núcleo amplo, também fundado na recorrência, de onde saem e para onde convergem todas as outras partes de uma composição" (Tatit, 2007b:77).

${ }^{14} \mathrm{O}$ desdobramento "fratura o núcleo temático em função do devenir propriamente musical. A segunda parte é a evolução melódica no plano extenso, "responsável pela solução sintagmática da canção popular" (Tatit, 2007b:77).
} 
da surpresa. Segundo Claude Zilberberg (2006b:136), "[a] surpresa rompe o(s) percurso(s)." Nesse caso, o clímax quebra com o trajeto da repetição que vinha se desenvolvendo para criar um outro. ${ }^{15}$

A concepção de que elementos repetitivos, por vezes acelerados no componente expressivo (como o caso do caminhar dos sujeitos na publicidade da cerveja Guinness), sejam capazes de gerar um efeito de desaceleração pode parecer, num primeiro momento, contraditória. Entretanto, ao insistir numa regra, num mesmo elemento, não há mudança. Onde não há mudança, não há corte ou ruptura. O sujeito permanece íntegro, em continuidade com o objeto. É apenas o excesso, o limite desse mecanismo que produzirá a tensão pela mudança. A insistência nos elementos de concentração produz uma retenção do tempo e uma valorização dos limites e saliências, características de uma escolha por valores remissivos, que geram inibição e parada. A temporalidade remissiva é expectante, espera a mudança. A insistência implosiva da repetição é, como já previa Saussure ao tratar do grupo implosivo-explosivo, o nascimento de seu oposto. $\mathrm{O}$ termo escolhido por Zilberberg (2006b:137) para descrever a temporalidade remissiva reflete essa perspectiva de uma inversão. De acordo com o autor, o termo cronopoiese traz em seu étimo simultaneamente o tempo (crono) e a criação (poiese). Ora, se dizíamos que o espalhamento do ritmo pelo discurso nega a progressão do tempo e o seu caminho vai na direção de um eterno retorno ao início, apenas será possível entender a temporalidade remissiva como sendo criação de tempo, afinal, a permanência na parada nada mais é que um cultivo da espera, um estágio privilegiado para a retomada da progressão temporal.

Vejamos como essa discussão se reflete nos casos particulares analisados nos capítulos anteriores.

No anúncio da Budweiser, como primeiro exemplo, temos a repetição das sílabas da cerveja, mas isso não é tudo. Toda a figuratividade dos sapos é repetida. São três figuras de caracterização semelhante: três sapos na mesma lagoa, onde cada um repete incessantemente a sua sílaba monotônica. É esse processo de repetição que vai, conforme vimos na análise, construindo a tensão do insólito. Já no anúncio da Guinness, é a insistência

\footnotetext{
${ }^{15}$ Exploraremos a estrutura do clímax em detalhes na seção seguinte.
} 
no andar, nas transformações figurativas sem que haja de fato uma mudança subjetal, que cria, na ordem extensa, a expectativa da conclusão e prepara o enunciatário para o momento culminante. Mais localmente, no que chamamos de terceira parte, onde se passa a segunda sanção, temos um elemento de repetição na música que anuncia o veredito acerca da bebida. Na música temos as mesmas duas notas, bastante destacadas e fortes, repetidas três vezes ao mesmo tempo em que, na letra, houve-se cantar "of life / of life / of life". Para a música e entra a única fala do filme, um "puá!" feito pelo peixe que declara sua desaprovação à bebida que, afinal, não é a cerveja, objeto de seu querer. Retoma-se a música em descendência para a conclusão no que chamamos de epílogo do filme, no qual os sentidos vão convergir para a figura dos copos e o bordão.

Da comparação desses dois textos, vemos que estão salientados, no anúncio da Budweiser, elementos da superfície textual - como é o caso das sílabas - e elementos figurativos. No filme da Guinness, o que se mantém são os traços subjetais. Percebemos o elemento reiterado no mecanismo de transformações figurativas. Em outras palavras, é do contraste de uma subjetividade constante com uma figuratividade transfigurada em intervalos disseminados pelo texto que percebemos as transformações como um fator de repetição. Assim, ao serem distribuídas no discurso, as regularidades levam consigo a diferença (nesse caso, figurativa) e conferem direção ao discurso. No entanto, conforme nossas observações feitas até aqui, a repetição chega a um momento de saturação em que surge a necessidade de uma mudança. A repetição de um mecanismo sintáxico extenso é substituída por uma repetição intensa - local ${ }^{16}$ — de termos contingentes, ou seja, os elementos que vinham sendo repetidos ao longo do texto dão lugar a novos elementos repetitivos, que operam de forma tônica e local, como os elementos musicais mencionados. Essa substituição da repetição extensa pela intensa parece reforçar ainda mais a concentração no texto. Essa "concentração da concentração" anuncia o limite, que dá lugar à distensão.

No filme do Submarino, vemos a repetição especialmente destacada no arranjo das palavras-objeto na tela. Há sempre uma mesma ordem de introdução de cada termo e de sua modificação, como exploramos na

\footnotetext{
${ }^{16}$ Grosso modo, os elementos extensos se aplicam a todo o enunciado, enquanto os intensos dizem respeito a processos locais (cf. Hjelmslev 1991a:175-177; 1991b; e Zilberberg 1986a).
} 
análise. Em cada etapa o novo item lexical é apresentado num contexto já conhecido composto pelo cenário, as fontes de caracteres gráficos, a base da música. Sobre esses componentes são introduzidas modificações figurativas mínimas, no movimento das letras na tela e na música, mas, a cada ciclo, tudo retorna ao padrão instaurado na repetição. A repetição e a perspectiva de conjunção constantes fazem crescer a suspeita da presença de um antissujeito (Tatit, 2007a:31). Conforme desenvolvido na análise do Capítulo 3, trata-se de um antissujeito enfraquecido. Ele pode ser percebido em elementos muito sutis, como as notas tensas na música ou a impossibilidade de realização dos objetos fantásticos propostos no filme. De resto, ele se faz presente justamente pela concepção saussuriana de um vai-e-vem dos valores, ou seja, um antissujeito excessivamente atonizado já é prenúncio de sua provável recuperação num momento seguinte, caso contrário teríamos a extinção dessa categoria actancial. Isso gera a expectativa de que algo deve se transformar. Essa expectativa de mudança faz aumentar a tensão e aponta para uma conclusão.

Se nesses três anúncios, para que a repetição se configure em acúmulo de tensão, deve o enunciatário recorrer à memória - ainda que seja a uma memória muito recente no tempo, visto que as peças são bastante curtas -, nosso primeiro anúncio traz justamente a ideia de vestígios que, acumulados pela repetição, estão na base da construção do texto. O filme do Ministério da Justiça francês usa de um mecanismo semelhante ao utilizado no anúncio do Submarino, no sentido de que letras aparecem e somem da tela. Entretanto, apenas no caso do Ministério da Justiça, as letras deixam para trás uma marca, que rapidamente descobriremos ser um ferimento no rosto, que não desaparece como as palavras. $\mathrm{O}$ acúmulo dessas feridas vai desembocar na morte do ator do enunciado, criando o máximo da tensão no texto. Também a música, nesse texto, contém repetições recorrentes. A pulsação na primeira fase vai se tornando cada vez mais saliente até que, quando cessa, se interrompe como se fosse uma batida cardíaca que deixa de existir, também confirmando a morte do ator. Tudo isso sem falar no fato de o jogo original de bem-me-quer-mal-me-quer ser ele mesmo baseado na repetição do gesto de arrancar pétalas e proferir a fórmula feita - jogo cuja única motivação seria descobrir ao final os verdadeiros sentimentos da pessoa amada, ou seja, um elemento de revelação e de surpresa que emerge da ritualização lúdica permitida pelo jogo. Nesse caso, como no do anúncio, os sentimentos do jogador-protagonista em 
relação ao seu objeto são conhecidos e confessos desde sempre, sendo sua permanência reiterada a cada pétala, ao passo que os da pessoa amada só podem ser descobertos ao final do jogo, como surpresa, quando, terminadas as pétalas, não há mais como repetir o gesto. No caso da peça publicitária, o desvelamento dos sentimentos da pessoa amada aparece num percurso da decepção, manifesta de forma duplamente irreversível: por causa da morte da protagonista (que terá sabido "tarde demais") e porque, quanto à pessoa amada por ela, a violência passa de simples disposição afetiva a disposição ética (do ser), coisa que ninguém terá realmente percebido apesar da repetição dos gestos de "arrancar as pétalas".

Na revisão das análises dos anúncios, levantamos elementos repetitivos tanto da expressão como do conteúdo, repetições de itens singulares como de mecanismos sintáxicos. Em todos os casos, a permanência no esquema repetitivo produziu o fechamento discutido acima que, com a retenção da progressão temporal, fazia a todo tempo crescer uma tensão expectante pela mudança. Em consonância com o modelo saussuriano, o fim da retenção é seguido de uma abertura para a mudança e para a resolução do texto. Veremos a seguir como se configura semioticamente essa mudança.

\subsection{Estrutura de Clímax}

Invariavelmente todos os anúncios analisados apresentam uma estrutura de clímax. O que queremos dizer com isso é que há uma direção constante para a narrativa desenvolvida em cada peça. Aqui consideramos a direcionalidade da narrativa não exatamente no sentido greimasiano do encadeamento lógico das fases do percurso narrativo, que naturalmente também está presente, mas no sentido do direcionamento da tensão. Todas as peças analisadas parecem culminar num ponto de convergência de todos os sentidos que vinham sendo construídos no texto. No decorrer do filme, percebemos, regularmente, a concorrência de estratégias para criar um aumento gradual de tensão, que vai recrudescendo até um limite, a que chamamos clímax. O clímax coincide, em quase todos os anúncios, à parte final do texto. 
Essa estrutura de tensões nos filmes publicitários analisados guarda uma semelhança curiosa com a estrutura do conto literário conforme entendido por alguns autores. Segundo Júlio Cortázar (1993:151), o romance se deixa desdobrar em arcos de história, variações de intensidade até "o esgotamento da matéria romanceada", enquanto o conto deve manter-se num limite, na forma fechada e tensa de uma esfera (Cortázar, 1993:228). Nádia B. Gotlib (2000 :39-41) explica que, para muitos teóricos na tradição iniciada por E. A. Poe, o tamanho reduzido do conto está fortemente ligado a uma unidade de construção, à tensão unitária, ou seja, a essa estrutura que se direciona a um clímax, exatamente como se passa com os textos aqui estudados, conforme veremos a seguir.

Na medida em que o filme vai, ao longo de toda a sua duração, construindo uma tensão, é possível concebê-lo como um texto centrado na retenção. Em outras palavras, as publicidades analisadas giram sempre em torno de um mistério, algo que revela um propósito ao percurso que se constrói e, ao mesmo tempo, surpreende o enunciatário. No anúncio do Submarino, por exemplo, temos a instauração da tensão na abertura de uma frase condicional ("se existisse..."), que, ao se manter em aberto por quase toda a duração do filme, deixa suspensa a oração principal que lhe dá sentido. Há também um crescimento da tensão pela repetição - nesse caso, de uma fórmula de apresentação dos elementos na tela (conforme exploramos na seção anterior). Ao final da série, temos o pico de tensão que se dissolve com o fechamento da frase que havia sido iniciada na abertura do filme: "se existisse... Você compraria? A gente venderia". Fecha-se o anúncio com o momento de distensão e a apresentação da marca.

O quadrado abaixo ilustra a passagem da primeira parte, na qual mantém-se a tensão crescente, ou a continuação da parada (Tatit 2002: 200201; 2007a:54), ao clímax, que corresponde à parada da parada (Zilberberg, $2006 b: 147)$. 


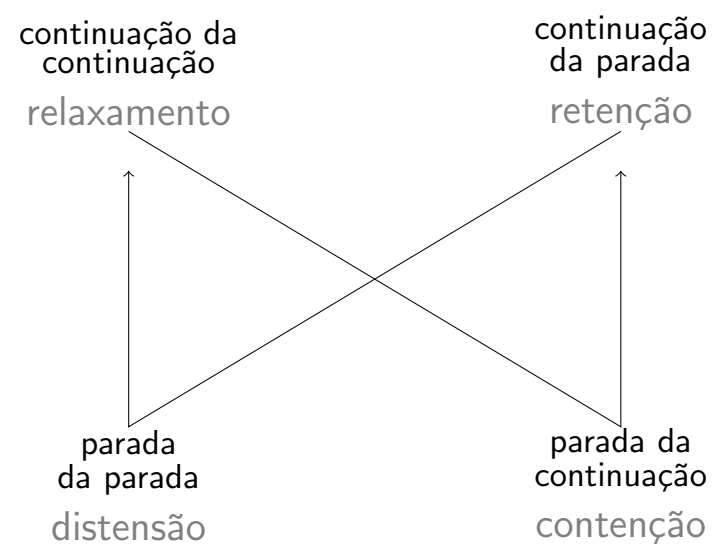

Num trajeto semelhante, o filme da Budweiser, ao insistir nas sílabas desconexas emitidas pelos sapos, mantinha o enunciatário numa situação de suspensão do saber, ou seja, os elementos apresentados no texto não pareciam se combinar de forma a construir um único sentido. A indecisão acerca de como se compõem as partes provoca "uma 'inquietude' no enunciatário, que é deixado na ignorância do estatuto veridictório do saber adquirido" (Greimas \& Courtés, 1993 :372-373). ${ }^{17}$ Segundo José Roberto do Carmo Jr., isso produzirá uma mudança de posição actancial no enunciatário:

Esse efeito de ambiguidade se traduz numa suspensão epistêmica na instância do enunciatário, porque este já não reconhece um sentido único no enunciado que tem diante de si. [...] Resta ao enunciatário paralisar-se, dividido num conflito modal entre o saber e o não saber. O enunciatário, sujeito do fazer cognitivo, se vê, repentinamente, transformado num sujeito passional. (do Carmo Jr., 2009:181-182)

Diferentemente dos objetos analisados por J. R. do Carmo Jr. — cartazes publicitários - , os filmes publicitários se desenrolam no tempo. $\mathrm{O}$ fato de os anúncios se estenderem no tempo não trará, entretanto, relaxamento. Ao contrário, a permanência nesse estado de não-saber produz um acréscimo de tensão que vai se sustentar e crescer na maior parte do anúncio, gerando o mesmo efeito global de retenção. Nos últimos cinco segundos do filme (de

\footnotetext{
17 “...] la suspension de la modalisation épistémique fait apparaître, à un moment donné, un faire informatif neutre, provoquant ainsi une 'inquiétude' de l'énonciataire, laissé dans l'ignorance du statut véridictoire du savoir reçu."
} 
um total de 30 segundos), vemos a virada que vai revelar o enigma e trazer a distensão da solução. A resolução representa, dessa forma, um salto. Em outras palavras, fomos sendo apresentados a elementos fragmentários, que apontavam em direções distintas. Um caminho possível para a narrativa poderia ser um encaminhamento gradual desses elementos para um mesmo sentido. Ao invés disso, o que percebemos é uma súbita convergência, a ultrapassagem de um limite. Nesse instante, cria-se um todo e, com ele, as partes que o compunham. Antes de percebermos que formam um todo, esses elementos não se manifestam como sendo partes de um conjunto. É a apresentação do todo como tal que ressignifica os fragmentos como partes dessa totalidade.

O termo "distensão" pode levar à conclusão precipitada de que estaríamos numa zona de relaxamento. Ao contrário, a noção de parada da parada tem um caráter pontual, se comparada aos termos contrários (continuação da parada e continuação da continuação). Os termos "parada da parada" e "parada da continuação" remetem a uma etapa de transformação, de virada. Em especial, a parada da parada, conforme apresentada aqui na análise dos filmes publicitários, diz respeito a um ponto de convergência e concentração de sentidos. Nos textos, percebe-se a rápida passagem por essa fase na superfície textual: a distensão corresponde aos segundos finais do texto. O relaxamento propriamente dito viria na continuação do percurso que, no quadrado, corresponde à continuação da continuação. Entretanto, os filmes mencionados acabam no momento de distensão. Se entendermos essa fase como pontual e como uma concentração de sentidos, a escolha do enunciador se mostra bastante reveladora, uma vez que estamos no momento de mais alto impacto, no limite da tensão, em que tudo o que resta é uma mudança, uma passagem para o relaxamento. Ademais, se voltarmos-nos à questão do gênero publicitário, podemos levantar a hipótese de uma escolha do enunciador por uma finalização no momento de maior impacto.

No caso da Guinness, teremos o mesmo movimento tensivo global. Logo no início, é o fim da narrativa que se apresenta, antes de mais nada. Isso produz no enunciatário uma ignorância do contrato inicial, que em última análise é aquilo que dá coerência à narrativa. Num filme um pouco mais longo (50 segundos), novamente é nos cinco segundos finais que temos a distensão. Nesse caso, entretanto, temos as partes mais escandidas, no sentido de que há (i) uma introdução, em que os atores do enunciado 
experimentam a cerveja, (ii) o desenvolvimento que, conforme explicado na análise, cria a oposição aos momentos de sanção, (iii) uma segunda sanção, que conclui a narrativa, e (iv) o momento de resolução: o clímax. Nesse anúncio, o clímax equivale à entrada do epílogo com a marca, que, ao trazer o bordão "Good things come to those who wait"18, explicita o contrato de manipulação e, com isso, amarra as duas sanções. O momento final age, assim, de forma extensa sobre toda a narrativa que o precedeu, o que é justamente a propriedade mais saliente do contrato. Novamente, há uma insistência num percurso cujo propósito está suspenso, uma vez que o contrato só se revela ao final. Associada aos elementos repetitivos que analisaremos abaixo, a expectativa de uma solução cria uma tensão a todo momento crescente, que podemos associar à retenção. O clímax ao final do texto trará, de um lado, a explicação das partes, mas também vai se configurar como ponto de convergência dos sentidos desenvolvidos no correr do texto.

Está em grande relevo, neste último anúncio, uma diferença entre a direção global de tensão no texto e as modulações locais. Se, por um lado, é possível argumentar, como acabamos de fazer, que o texto como um todo se dirige da retenção à distensão, também mencionamos fases da narrativa que têm cada uma sua variação de tensão. Comparando os momentos de sanção (i e iii) com o desenvolvimento (ii), veremos que as extremidades — as sanções — são mais impactantes que a fase que as une ${ }^{19}$, mas é da combinação dessas fases oscilantes com o epílogo que apreendemos a direção global da tensão. Essa diferença entre local e global faz supor um alcance dos mecanismos tensivos tanto à ordem extensa como intensa do texto. Dito de outra forma, é possível que o modelo tensivo se preste a diferentes níveis de descrição, seja na análise de modulações intensas, de ordem local, como nos grandes percursos globais da tensão no texto. ${ }^{20}$

Nos três casos estudados até o momento, vemos que, uma vez encerrado o anúncio, resta ao enunciatário absorver esse impacto e retraçar o percurso do filme, a fim de reconstruir as partes que convergiram ao final. Em outras

\footnotetext{
${ }^{18}$ Uma expressão semelhante em português é: "quem espera sempre alcança".

${ }^{19}$ Essa análise é corroborada pelos elementos de expressão e conteúdo que estudamos em detalhes no capítulo 4 .

${ }^{20}$ Se estivermos corretos em supor essa estratificação de níveis entre o geral e o parcial na variação de tensividade, então esse tipo de mecanismo pode vir a ser útil para analisar textos mais longos e dar conta de certas variações de andamento e impacto no decorrer do texto.
} 
palavras, o enunciatário deverá deixar o polo impactante da parada da parada (a resolução) e entrar no relaxamento da retomada que, ao explicar as partes, desacelera o conteúdo. Especialmente nessas três publicidades, com fortes valores euforizantes, o relaxamento é construído por meio da conjunção que se opera entre o enunciatário e o texto que ele foi capaz de desvendar. A ideia de que o enunciatário deve retomar o texto em meio ao clima euforizante da conjunção final também pode ser entendida como criadora de um enunciador (de textos publicitários) que busca fazer lembrar (da marca, talvez). Em outras palavras, ao gerar a necessidade de uma retomada para que o enunciatário possa costurar os pedaços que convergiram ao final do texto, o enunciador está apontando na direção da potencialização do texto na memória.

Resta voltarmo-nos para o anúncio do Ministério da Justiça francês, que apresenta certas escolhas destoantes do conjunto dos filmes estudados. Apesar de reconhecermos um clímax, ele não aparece, como nos demais, ao final do texto. Enquanto nos outros três anúncios o clímax compõe a pequena parte final, nesta peça, a expectativa e a tensão vão se construindo na primeira metade do filme, na qual o espectador é apresentado gradualmente aos ferimentos da moça. Quando há a mudança (na câmera, na música e em todo o conteúdo a que vínhamos sendo apresentados), resolvese a narrativa e, ao enunciatário, é revelada a morte que se anunciava nos ferimentos. É claramente o clímax. Depois disso, o filme ainda se desenrola por pouco mais de quinze segundos, o que equivale a um terço do tempo total - muito mais significativo que os cinco segundos que pareciam tão constantes nos demais anúncios. Podemos nos perguntar, então, a que vem essa conclusão tão alongada. Naturalmente há um conteúdo (que também entra na persuasão do enunciatário) ainda a ser apresentado, como, por exemplo, a estatística de violência doméstica na França e o apelo à reação. Cremos, porém, que outros fatores — talvez mais prementes - estão também em jogo.

De um lado, notamos a mudança de tom: se antes tínhamos filmes que criavam um tom mais leve ou até cômico, no caso do anúncio do Ministério da Justiça, temos uma peça trágica e bastante dura. Nesses termos, retomamos Claude Zilberberg (2006a:cap. 4), quando propõe que a sintaxe 
tensiva é reparadora: o sujeito, quando tomado por um acontecimento arrebatador, procurará desacelerar e retomar o caminho percorrido para assim tentar refazer o sentido do que se passou. Nos outros anúncios, todo o percurso de desaceleração era deixado para um outro momento. ${ }^{21}$ Este, entretanto, leva o enunciatário da retenção, paulatinamente, ao relaxamento. Ao evento altamente tônico da morte da moça, segue-se a cena repetitiva e desacelerada do necrotério, como que para dar tempo suficiente ao sujeito de assimilar o que se passou. Essa cena do necrotério se desenrola em segundo plano, enquanto novas mensagens vão se construindo, como a estatística que acabamos de citar. Até por poder estar em segundo plano, vê-se que houve uma desaceleração do conteúdo.

Do outro lado, é preciso levar em conta o objeto tratado neste anúncio em oposição aos demais. Nos filmes do Submarino, da Budweiser e da Guinness, há um produto a ser vendido, uma marca a ser guardada. O anúncio do Ministério da Justiça francês defende uma causa, um valor que se pretende mais abrangente, porque social. Essa diferença nos faz supor diferentes estilos de convencimento do enunciatário. Na publicidade focada em produtos e marcas, vemos a construção do enunciatário como sujeito do ser. Quando se encerra o filme, está sob a influência do impacto dos sentidos que convergiram inesperadamente no filme. Se o sujeito age sob a influência desse impacto, seus atos tomarão a configuração de uma ação desordenada, uma ação por impulso (Greimas, 1983:245-246). Essa perspectiva parece casar perfeitamente com a publicidade de produtos supérfluos. No entanto, no caso da publicidade institucional, podemos entender o porquê das duas fases de retenção e relaxamento mais desenvolvidas.

No anúncio do Ministério da Justiça, acompanhamos um trajeto de recrudescimento de tonicidade e andamento do conteúdo na primeira parte, até um pico, no qual se reconhece a parada da parada. Nesse momento, o sujeito está no auge da passionalização, paralisado pelo impacto. Entretanto, isso não basta. O enunciatário construído nesse texto deve, sim, ser mobilizado pelo tema, mas deve também agir de forma planejada e consequente, por meio das instruções deixadas pelo enunciador. Não se espera desse enunciatário uma reação "no calor da hora", que levaria a uma

${ }^{21}$ Naturalmente que, uma vez que não está contemplado no texto, só é possível supor esse momento de relaxamento. No entanto, como está previsto no modelo e os termos do quadrado fecham um percurso de pressuposições e encadeamentos, a própria teoria faz supor que esse momento se faça presente, mesmo sem estar realizado no texto. 
atitude desordenada. Espera-se uma ação pelas vias legais - apresentadas no quadro final com telefone, página na Internet e a chancela do Ministério. ${ }^{22}$ Dessa forma, uma vez passado o pico de tensão, o texto conduzirá o enunciatário do polo da distensão para a fase de relaxamento, dotandoo, assim, das modalidades necessárias para que deixe de ser um sujeito do sofrer ou suportar e passe a um sujeito do agir (Zilberberg, 2007b:22). Essa passagem está até mesmo marcada na superfície textual por meio da palavra de ordem que clama à ação: "Réagissons...".

Por fim, é curioso notar que a apresentação da marca é sempre expressa na terceira parte, ao final dos anúncios. Também esse fato parece intuitivo. Em primeiro lugar, por estar ao final, a marca ganha saliência e constitui o elemento principal a ser lembrado. Se considerarmos, porém, que ela aparece no momento de distensão, a marca insere-se no clima de cumplicidade da celebração final. Ainda que o tema do anúncio seja disfórico, como o tema da violência doméstica tratado na peça do Ministério da Justiça francês, as figuras e cores que caracterizam a instituição governamental surgem no clima de envolvimento criado pelo corpo do texto. Isso se dá por conta da necessidade de estabelecimento claro do contrato manipulatório, que só pode ser firmado mediante a explicitação e o compartilhamento de valores entre destinador e destinatário. A adesão a esses valores vai sendo construída no decorrer do texto e, dessa forma, é apenas ao final que uma plena adesão pode estar garantida. Por outro lado, mas ainda em relação à constituição do contrato, é preciso considerar a consolidação das dimensões cognitiva e tímica do texto. Quanto à primeira, vemos que a marca é inserida quando todos os elementos já foram apresentados e todos os termos geradores de suspense ou não-saber já haviam sido revelados. Podemos dizer, grosso modo, que o enunciatário já "entendeu" o texto. Isso porque, nos três filmes comerciais (Budweiser, Guinness e Submarino) — como em muitas publicidades - , há uma charada a desvendar. A sacada final gera cumplicidade entre enunciador e enunciatário: este foi capaz de resolver o mistério que havia sido proposto. A solução do mistério, que muitas vezes comporta um elemento lúdico, é crucial para a criação do efeito de conjunção do enuncitário com o texto e, por extensão, com a marca. Quanto

\footnotetext{
${ }^{22}$ Esse é o mesmo trajeto por vezes reconhecido como o percurso do estado de direito ilustrado na Oréstia de Ésquilo (1991). No primeiro livro, Agamêmnon, a justiça desordenada de Clitemnestra, ou seja, sua resposta passional ao assassinato da filha, produz uma reação em cadeia que só será quebrada quando, da justiça privada, se passar à justiça pública e ordenada do tribunal de Atena, no último livro, Eumênides.
} 
à dimensão tímica, é possível observar que a marca vem associada aos objetos afetivamente eufóricos oferecidos ao final (como "prêmio" a quem acompanhou o desenvolvimento narrativo do texto). Seria problemático que ela comparecesse em qualquer outra posição, como, digamos, no meio da peça, quando a narrativa ainda está se desenrolando e com a presença de valores disfóricos, antes da consagração final. 


\section{Capítulo 7}

\section{Conclusão}

As the strong man exults in his physical ability, delighting in such exercises as call his muscles into action, so glories the analyst in that moral activity which disentangles. [...] His results, brought about by the very soul and essence of method, have, in truth, the whole air of intuition.

Edgar Allan Poe 
No capítulo anterior, cobrimos alguns dos pontos que compõem os objetivos estabelecidos na Introdução. Em especial, levantamos alguns dos elementos da expressão que se mostraram relevantes na composição da cifra tensiva presente nos anúncios publicitários analisados. Procuramos, também, apontar algumas generalizações no uso de elementos da expressão e do conteúdo e sugerir alguns meios pelos quais esses elementos entram na composição da tensividade dos textos de publicidade. Vamos agora retomar de maneira mais geral a análise da tensividade de cada texto examinado, a fim de traçar um panorama de como expressão e conteúdo estão relacionados semioticamente nesses textos.

Numa comparação entre estilos clássico e barroco, Zilberberg (2006a :3335) toma como traço do conteúdo o andamento e como traço da expressão o contorno. $\mathrm{O}$ andamento é uma subdimensão da intensidade; o contorno, na medida em que revela as operações de triagem e mistura no texto, faz parte da extensidade. O autor associa, então, andamento e contorno num gráfico que forma uma curva inversa.

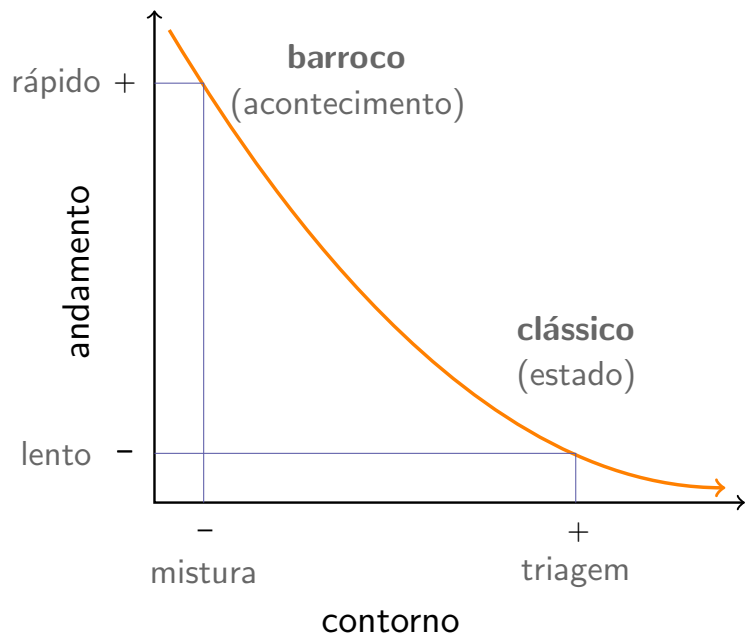

A associação de expressão e conteúdo, nesses termos, poderia levar à conclusão apressada de que conteúdo está necessariamente ligado a intensidade e expressão a extensidade. ${ }^{1}$ No entanto, é possível reconhecer

\footnotetext{
${ }^{1}$ Não estamos com isso dizendo que Zilberberg faça a associação: expressão : conteúdo :: extensidade : intensidade. Estamos apenas apontando que, ao construir o gráfico tomando elementos dos diferentes planos da linguagem, essa associação fica latente. Esse entendimento se reforça ainda mais pela relação de pressuposição espelhada: o conteúdo é pressuposto à expressão da mesma maneira que a intensidade é pressuposta à extensidade.
} 
- como exemplificamos nas análises e retomaremos a seguir - elementos de espacialidade e temporalidade, isto é, da extensidade, no conteúdo, bem como movimentos de tensão e andamento, isto é, da intensidade, na expressão. A composição de extensidade e intensidade em cada uma das dimensões do signo pode resultar em curvas semelhantes - ambas inversas ou ambas conversas. Nesse caso, associar uma dimensão do conteúdo a uma da expressão num mesmo gráfico não traria desencontros na análise. Entretanto, se expressão e conteúdo apresentarem curvas discordantes - digamos a primeira inversa e a segunda conversa -, a representação num único gráfico pode deixar de apontar justamente essa diferença. A relação entre expressão e conteúdo nos parece, assim, mais uma relação entre curvas tensivas do que entre eixos do gráfico. Passamos agora aos casos particulares que exemplificam essa relação entre as curvas.

Ao investigarmos a direcionalidade da tensão nos filmes, no capítulo anterior, ressaltamos que, no anúncio da Guinness, havia uma direção global da tensão no texto, mas também podíamos reconhecer modulações locais, contribuindo para o desenvolvimento da narrativa. São essas variações locais que encontrarão correlatos na expressão. Já no capítulo da análise da cerveja Guinness (Capítulo 4), localizamos uma diferença importante entre o que chamamos de momentos de sanção e a fase intermediária, em que vemos o caminhar dos atores do enunciado. Analisando o plano do conteúdo do texto, observamos uma espacialidade fechada, no primeiro momento de sanção, tanto por reconhecermos o espaço interno de um bar, como porque não há movimentação de grande alcance feita pelos atores do enunciado: eles estão perfeitamente concentrados na fruição de seu objeto de desejo - a cerveja. É uma cena de forte impacto tímico, pois é possível perceber o prazer expresso na gestualidade facial dos atores. Em contrapartida, a fase subsequente da narrativa será marcada por valores inversos a esses. $\mathrm{O}$ espaço se abre em grandes tomadas externas, os atores se põem em movimento para cobrir uma vasta extensão e seus estados de alma aparecem cada vez menos salientados. A segunda sanção representa um retorno aos mesmos valores da primeira. Podemos, assim, representar esses movimentos num gráfico inverso:

Esse paralelo, entretanto, não se sustenta, conforme a argumentação e os exemplos que levantaremos nesta Conclusão. 


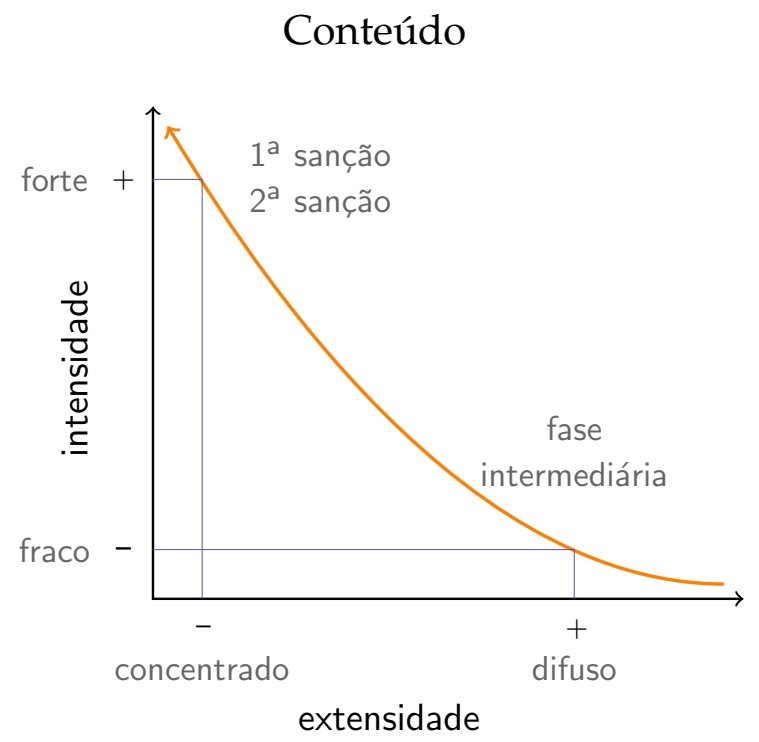

Não por acaso, o último quadro com os três copos de cerveja apresenta os mesmos valores dos momentos de sanção. Esse momento final representa o ponto culminante na estrutura de clímax (desenvolvida no Capítulo 6) e, portanto, o máximo de impacto no texto.

Da análise do plano da expressão, entretanto, obteremos uma curva bastante distinta. Se pensarmos na temporalidade ou na espacialidade convocada no plano da expressão, teremos valores semelhantes àqueles encontrados para o conteúdo em cada fase da narrativa. Os momentos de sanção duram pouco no tempo e percebemos uma predominância de enquadramentos fechados. Na fase intermediária, vemos o inverso: trata-se da parte mais longa do texto, em que predominam tomadas mais à distância. É no andamento que os valores da expressão e do conteúdo são discordantes. Onde apreendemos acelerações no conteúdo, temos desacelerações no vídeo e na música, ou seja, os impactantes momentos de sanção apresentam música e vídeo mais lentos. Quando o filme e a canção ganham velocidade, o impacto do conteúdo fica esmaecido. Assim, no trecho intermediário, em que a previsibilidade das transformações figurativas dos atores está perfeitamente estabelecida e não há surpresas, a música cresce em velocidade, ao assumir uma levada de rock, e o filme passa a ser rodado de forma acelerada. Os valores semelhantes, obtidos no eixo da extensidade e acompanhados de uma intensidade perfeitamente invertida 
em relação àquela do conteúdo, vão gerar um gráfico converso:

Expressão

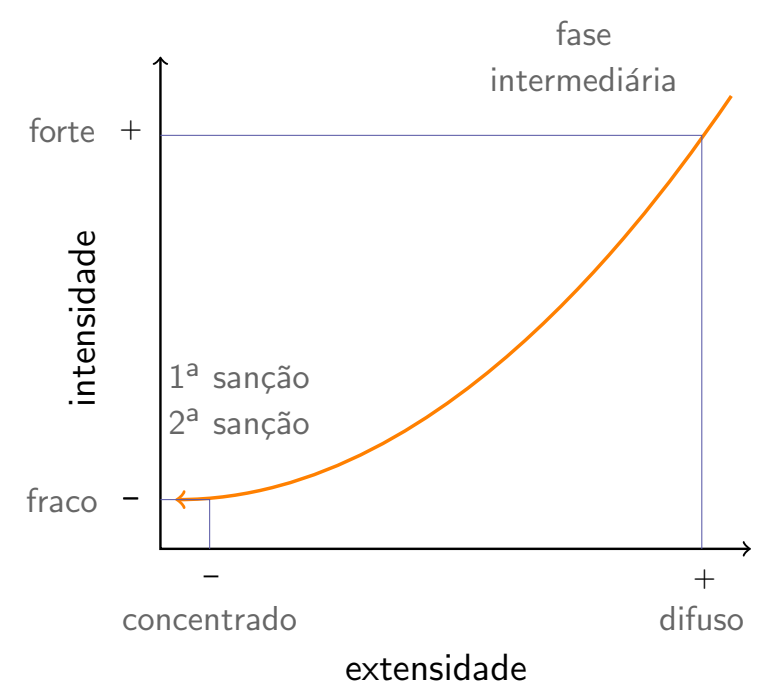

No Capítulo 5, já analisamos em pormenores a interação entre as variações tensivas da expressão e do conteúdo na publicidade da Budweiser. Assim como no caso da Guinness, obtivemos um esquema converso para a expressão e inverso para o conteúdo. No entanto, é o entrecruzamento dos esquemas da expressão e do conteúdo em cada caso que distancia as duas análises. Se, na Guinness, a lentidão do andamento na expressão surge no texto associado à sua aceleração no conteúdo, na Budweiser, o mais vivo andamento na expressão coincide com a aceleração também no conteúdo. Parece-nos mais habitual a relação encontrada no anúncio da cerveja Guinness. Podemos mencionar uma série de filmes que usam justamente da desaceleração da câmera para ressaltar as cenas de mais impacto. ${ }^{2} \mathrm{~A}$ relação invertida no anúncio da Budweiser parece ser uma idiossincrasia, ou melhor, uma estratégia particular, que contribui para singularizar esse anúncio.

\footnotetext{
${ }^{2}$ Como exemplo radical, que marcou época, vale citar a trilogia Matrix, dos irmãos Wachowski. Nos filmes da série, para valorizar a intensidade da luta e das habilidades e peripécias do herói, o tempo era congelado e a câmera girava em torno dos personagens, quando estavam em pleno ar.
} 
O anúncio do Submarino inicia-se com valores de passagem, distensos. Na música como no componente visual, o texto ganha rapidamente uma direção, uma lei de sequenciamento de seus componentes que organizam as expectativas do enunciatário. Isso garante baixos valores de intensidade e altos valores de extensidade - não vemos, portanto, uma presença importante de um antissujeito. Entretanto, a permanência nesse estado e a recorrência excessiva da regra geram uma saturação, uma espera de mudança. A repetição tanto na expressão como no conteúdo age como elemento concentrador no eixo da extensidade, uma vez que gera a sensação de que não se sai do lugar, de que não há evolução no tempo e no espaço. Assim, se o texto abre com valores de pouca intensidade e grande extensidade, a própria insistência nesses valores distensos pode provocar a necessidade de restabelecimento na dimensão da intensidade. Uma nota musical com volume mais intenso e o elemento visual pulsante fazem crescer os valores da subdimensão da tonicidade. Essas são as marcas indicadoras de que os objetos que se repetiam cessaram para dar lugar à resolução do texto. De um ponto de vista extenso, expressão e conteúdo apresentaram as mesmas variações de intensidade e extensidade, compondo valores tensivos espelhados. Não percebemos, como nos filmes até aqui comentados, grandes variações no andamento da expressão. Há, ainda assim, uma variação local que é digna de nota. Trata-se de uma pausa, na música, antes da passagem para a terceira parte, que encerra o filme. É a desaceleração na expressão que antecede o desfecho final. Esse tipo de desaceleração que anuncia o impacto iminente pode ser visto também na publicidade da Guinness: ele prepara a segunda sanção. ${ }^{3}$

No anúncio do Ministério da Justiça francês, o elemento visual está para a espacialidade assim como o musical está para a temporalidade — ambos subvalências da extensidade. No plano visual, na primeira parte, temos uma tomada em close up focalizando o rosto de uma moça. Como vimos, esse enquadramento cria uma espacialidade fechada na medida em que um único elemento toma todo o campo perceptivo. Também no conteúdo percebemos uma espacialidade contida, pois não há movimento nem reação

\footnotetext{
${ }^{3}$ Esse tipo de estratégia chega a ser um cliché dos filmes de suspense e terror - é uma espécie de silêncio de mau agouro. Encontramos um outro exemplo em Moby Dick, de Herman Melville. No capítulo 61, o silêncio precede o surgimento da baleia que, quando aparece, pega os marinheiros de surpresa, pois está já muito próxima do navio: "[ ... ] with a shock I came back to life. And lo! close under our lee, not forty fathoms off, a gigantic Sperm Whale lay rolling in the water..." (Melville, 1967:301).
} 
do ator do enunciado à progressão da narrativa. A moça permanece com uma mesma expressão facial serena, como se impassível aos ferimentos que vão progressivamente lhe cobrindo o rosto. O tempo, por sua vez, vai gradativamente se concentrando em função de uma música, que, ao apresentar um ritmo bastante marcado, coloca em evidência uma contenção da progressão cronológica. A permanência nessa temporalidade involutiva e espacialidade fechada corresponde a um aumento na tonicidade. $\mathrm{Na}$ entrada da segunda parte, abre-se a espacialidade, com uma tomada mais à distância. A música ganha direção num desdobramento melódico. No eixo da intensidade, temos uma minimização ligada à resolução do percurso narrativo. Mais uma vez, vemos a espacialidade na expressão semelhante à do conteúdo: ambas fechadas de início, passando à abertura na segunda parte. A espacialidade estabelece, por outro lado, uma relação inversa com os valores de andamento e tonicidade do conteúdo. No primeiro momento, em que a espacialidade é fechada, encontramos forte impacto e aceleração dos conteúdos tímicos. Quando entramos na segunda parte, há uma desaceleração, que se combina com a abertura da imagem para um enquadramento mais global. Essa abertura e essa desaceleração estão ligadas a um distanciamento do enunciatário, que pode ser percebido na superfície textual por meio das marcas enuncivas do componente verbal, por exemplo, mas também a própria desaceleração é reveladora desse distanciamento, uma vez que a lentidão do conteúdo supõe um sujeito capaz de entender e agir, não se trata mais apenas de um sujeito imobilizado pelo impacto da morte da moça (Zilberberg, 2007b:19).

Em cada uma dessas retomadas, procuramos mostrar de que forma a cifra tensiva da expressão pode se compor com a do conteúdo. Ainda que formando curvas tensivas distintas, é possível contrastar os gráficos da expressão com os do conteúdo. Esse contraste pode mostrar que a tensividade da expressão e a do conteúdo andam de forma paralela, ou seja, a expressão pode tomar uma configuração tal que vá reforçar a tensividade do conteúdo, reafirmando os sentidos construídos. Por outro lado, em alguns casos, as curvas tensivas da expressão podem tomar sentidos distintos daquelas do conteúdo. Nos casos em que havia esse contraste, pudemos contrastar, por exemplo, andamentos espelhados (Guinness), 
espacialidades conflitantes (Budweiser), etc. No caso da Guinness, reconhecemos as diferenças de andamento como uma estratégia que podia ser vista em outros textos. No anúncio da Budweiser, em que os andamentos da expressão e do conteúdo tomavam a mesma direção - contrariando, assim, as expectativas geradas pelas outras análises -, essa semelhança parecia ser central para a estratégia particular desse texto. Dessa forma, o mesmo instrumento de análise parece poder apontar tanto generalizações como eventuais idiossincrasias dos textos. Seja como for, a participação tanto do plano da expressão como do plano do conteúdo na composição dos valores tensivos parece francamente plausível, uma vez que estão ambos sujeitos às escolhas de uma mesma instância da enunciação e apresentam uma organização interna que gera efeitos de tensão no texto. As categorias bastante gerais propostas pela semiótica tensiva permitem justamente $\mathrm{o}$ uso de uma mesma metalinguagem para o tratamento dos dois planos. A escolha de uma metalinguagem comum ao mesmo tempo a expressão e conteúdo parece fazer aflorar as questões relevantes entre as duas dimensões do signo linguístico, contribuindo para uma maior comparabilidade entre os planos e trazendo dinamicidade às análises dos objetos semióticos para além das categorias semissimbólicas. 


\section{Referências Bibliográficas}

AuthIER-REvUZ, Jacqueline. "Hétérogéneité montrée et hétérogéneité constitutive: éléments pour une approche de lautre dans le discours." DRLAV, vol. 26, 91-151, 1982.

BARros, Diana Luz Pessoa de. Teoria do Discurso: Fundamentos Semióticos. São Paulo: Humanitas, 2 ed., 2001.

—. "Semiótica e retórica: um diálogo produtivo." In: LARA, Gláucia M P et al. (Ed.), Análises do Discurso Hoje, pp. 27-39. Rio de Janeiro: Nova Fronteira / Lucerna, 2008.

Benveniste, Émile. Problemas de Linguística Geral, vol. I. Campinas: Pontes / Editora da Unicamp, 4 ed., 1995. Tradução de Maria da Glória Novak e Maria Luisa Neri.

_. Problemas de Linguística Geral, vol. II. Campinas: Pontes, 2 ed., 2006. Tradução de Eduardo Guimarães et al.

Buarque, Chico. Chapeuzinho Amarelo. São Paulo: Berlendis e Vertecchia, 10 ed., 1987. Ilustrações de Donatella Berlendis.

Cortázar, Julio. Valise de Cronópio. Debates. São Paulo: Perspectiva, 2 ed., 1993. Tradução de Davi Arrigucci Jr. e João Alexandre Barbosa.

DARWIN, Charles R. The Origin of Species by Means of Natural Selection, or the Preservation of Favoured Races in the Struggle for Life. Londres: John Murray, 6 ed., 1872.

URL http://darwin-online.org.uk/contents.html\#books

Discini, Norma. Intertextualidade e o Conto Maravilhoso. São Paulo: Humanitas, 2 ed., 2004. 
DO CARMO JR., José Roberto. "Estratégias enunciativas na produção do texto verbovisual." In: Linguagens na Comunicação: Desenvolvimentos de Semiótica Sincrética, pp. 169-184. São Paulo: Estação das Letras, 2009.

ÉSQUILO. Oréstia. Rio de Janeiro: Zahar, 2 ed., 1991. Tradução, introdução e notas de Mário da Gama Kury.

FIorin, José Luiz. As Astúcias da Enunciação: as Caregorias de Pessoa, Espaço e Tempo. Ensaios. São Paulo: Ática, 2002.

. "Para uma definição das linguagens sincréticas." In: OliveIRA, Ana Cláudia Mei de \& TEIXEIRA, Lucia (Eds.), Linguagens na Comunicação: Desenvolvimentos de Semiótica Sincrética, pp. 15-40. São Paulo: Estação das Letras, 2009.

FLOCH, Jean-Marie. Petites mythologies de l'oeil et de l'esprit: pour une sémiotique plastique. Actes Sémiotiques. Paris / Amsterdã: Hadès / Benjamins, 1985.

. "Syncrétiques (sémiotiques )." In: GreIMAS, Algirdas Julien \& COURTÉS, Joseph (Eds.), Sémiotique: Dictionnaire raisonné de la théorie du langage, vol. Tomo 2, pp. 217-219. Paris: Hachette, 1986.

- European Perspectives on Consumer Behaviour, chap. The Contribution of Structural Semiotics to the Design of a Hypermarket, pp. 402-422. Hertfordshire: Prentice Hall, 1998.

FOnTANille, Jacques. "Affichages: de la sémiotique des objets à la sémiotique des situation." Nouveaux Actes Sémiotiques, vol. Actes de colloques: Affiches et affichage, 1, 2004.

URL http://revues . unilim.fr/nas/document .php?id=1487

Fontanille, Jacques \& ZilberberG, Claude. Tensão e Significação. São Paulo: Discurso Editorial / Humanitas, 2001. Tradução de Ivã Carlos Lopes, Luiz Tatit e Waldir Beividas.

GotliB, Nádia Battella. Teoria do Conto. Princípios. São Paulo: Ática, 10 ed., 2000.

Greimas, Algirdas Julien. Du sens: essais sémiotiques, chap. Conditions d'une sémiotique du monde naturel, pp. 49-91. Paris: Seuil, 1970. 
- Du sens II: essais sémiotiques, chap. De la colère: étude de sémantique lexicale, pp. 225-246. Paris: Seuil, 1983.

—. De l'imperfection. Périgueux, França: Pierre Fanlac, 1987.

GreIMAS, Algirdas Julien \& COURTÉS, Joseph (Eds.). Sémiotique: dictionnaire raisonné de la théorie du langage, vol. II. Paris: Hachette, 1 ed., 1986.

Greimas, Algirdas Julien \& COURTÉs, Joseph. Sémiotique: dictionnaire raisonné de la théorie du langage, vol. I. Paris: Hachette, 1993.

Greimas, Algirdas Julien \& FonTANILLE, Jacques. Sémiotique des passions: des états de choses aux états d'âme. Paris: Seuil, 1991.

HAMmaD, Manar. "L'énonciation: Procès et système." Langages, vol. 70, 35-46, 1983.

HJELMSLEV, Louis. Ensaios Linguísticos, chap. Ensaio de uma Teoria dos Morfemas, pp. 171-184. São Paulo: Perspectiva, 1991a.

- Le langage. Paris: Gallimard, $1991 b$.

- Prolegômenos a uma Teoria da Linguagem. Estudos. São Paulo: Perspectiva, 2 ed., 2003. Tradução de J. Teixeira Coelho Netto.

LA MoniCA, P. "Super prices for super bowl ads.” CNN Money, 2007.

URL http://money.cnn.com/2007/01/03/news/funny/superbowl_ads/ index.htm

LEMOS, Carolina Lindenberg. "Um chapéu amarelo e um capuz vermelho: uma leitura semiótica de Chapeuzinho Amarelo de Chico Buarque." CASA - Cadernos de Semiótica Aplicada, vol. 6(1), 1, 2008.

URL http://www.fclar. unesp.br/seer/index.php?journal=casa

Lopes, Edward. Metáfora: da Retórica à Semiótica. Documentos. São Paulo: Atual, 2 ed., 1987.

Lopes, Marcos. Modèles inductifs de la sémiotique textuelle. Ph.D. thesis, Université de Paris X, Nanterre, 2002.

Melville, Herman. Moby-Dick. Nova York: Bantam, 1967. 
RAugust, K. “Bud-weis-er: Computer-generated frogs and lizards give bud a boost." Animation World Magazine, vol. 1(37), 1, 1998.

URL http://www.awn.com/mag/issue3.7/3.7pages/3.7raugustbud. html

SAussure, Ferdinand de. Curso de Linguística Geral. São Paulo: Cultrix, 1997. Tradução de Antônio Chelini, José Paulo Paes e Izidoro Blikstein.

TATIT, Luiz. Musicando a Semiótica: Ensaios. São Paulo: Annablume, 1 ed., 1997.

- "Abordagem do texto." In: FIORIN, José Luiz (Ed.), Introdução à Linguística, vol. I. Objetos Teóricos, pp. 187-209. São Paulo: Contexto, 2002.

. Hjelmslev e as Bases Tensivas do Semi-simbolismo. São Paulo: Editora CPS, 1 ed., 2007a.

—. Semiótica da Canção: Melodia e Letra. São Paulo: Escuta, 3 ed., $2007 b$.

ZilberberG, Claude. "Extense/intense." In: Greimas, Algirdas Julien \& COURTÉS, Joseph (Eds.), Sémiotique: dictionnaire raisonné de la théorie du langage, vol. Tomo 2, pp. 81-82. Paris: Hachette, 1986a.

. "Transvaluation." In: GREIMAS, Algirdas Julien \& COURTÉS, Joseph (Eds.), Sémiotique: dictionnaire raisonné de la théorie du langage, vol. Tomo 2, pp. 242-246. Paris: Hachette, $1986 b$.

—_. "Relativité du rythme." Protée, vol. 18(1), 37-46, 1990.

—. "As condições semióticas da mestiçagem." In: CAÑIZAL, Eduardo Peñuela \& CAETANo, Kati E (Eds.), Olhar à Deriva: Mídia, Significação e Cultura, pp. 69-101. São Paulo: Annablume, 2004.

. Eléments de grammaire tensive. Nouveaux Actes Sémiotiques. Limoges: Pulim, 2006a.

- Razão e Poética do Sentido. São Paulo: Edusp, 2006b. Tradução de Ivã Carlos Lopes, Luiz Tatit e Waldir Beividas.

2006c. Tradução de Ivã Carlos Lopes e Luiz Tatit. 
—. “De la consistance.”, 2007a. Saint Maur, França.

—. "Louvando o acontecimento." Galáxia, vol. I(13), 13-28, $2007 b$. Tradução de Maria Lúcia Vissotto Paiva Diniz.

—. "Causerie sur la sémiotique tensive.", 2008. Saint Maur, França. 